\title{
Muscle strength, mobility and quality of life in patients with diabetic polyneuropathy : the influence of a functional strength and gait training
}

Citation for published version (APA):

ljzerman, T. H. (2016). Muscle strength, mobility and quality of life in patients with diabetic polyneuropathy : the influence of a functional strength and gait training. [Doctoral Thesis, Maastricht University]. Maastricht University. https://doi.org/10.26481/dis.20160205ti

Document status and date:

Published: 01/01/2016

DOI:

10.26481/dis.20160205ti

Document Version:

Publisher's PDF, also known as Version of record

Please check the document version of this publication:

- A submitted manuscript is the version of the article upon submission and before peer-review. There can be important differences between the submitted version and the official published version of record.

People interested in the research are advised to contact the author for the final version of the publication, or visit the DOI to the publisher's website.

- The final author version and the galley proof are versions of the publication after peer review.

- The final published version features the final layout of the paper including the volume, issue and page numbers.

Link to publication

\footnotetext{
General rights rights.

- You may freely distribute the URL identifying the publication in the public portal. please follow below link for the End User Agreement:

www.umlib.nl/taverne-license

Take down policy

If you believe that this document breaches copyright please contact us at:

repository@maastrichtuniversity.nl

providing details and we will investigate your claim.
}

Copyright and moral rights for the publications made accessible in the public portal are retained by the authors and/or other copyright owners and it is a condition of accessing publications that users recognise and abide by the legal requirements associated with these

- Users may download and print one copy of any publication from the public portal for the purpose of private study or research.

- You may not further distribute the material or use it for any profit-making activity or commercial gain

If the publication is distributed under the terms of Article $25 \mathrm{fa}$ of the Dutch Copyright Act, indicated by the "Taverne" license above, 


\section{Muscle strength, mobility and quality of life in patients with diabetic polyneuropathy}

The influence of a functional strength and gait training

Teunis Herman IJzerman 
Cover design: David Taylor

(C) T.H. IJzerman, Haarlem 2016

All rights reserved (including those of translation into other languages) to the author with exception of those chapters published by journals referred to. No parts of this dissertation may be reproduces in any other form by photo print, digital copy of other means - without written permission from the author or the copyright owning journal. 


\title{
Muscle strength, mobility and quality of life in patients with diabetic polyneuropathy
}

The influence of a functional strength and gait training

\section{Dissertation}

\author{
To obtain the degree of Doctor \\ at Maastricht University, \\ on the authority of the Rector Magnificus, Prof. dr. L.L.G. Soete, \\ in accordance with the decision of the Board of Deans, \\ to be defended in public on Friday 5 February 2016 at 12.00 hrs
}

by

Teunis Herman IJzerman 


\section{Supervisors:}

Prof. dr. H.H. C.M. Savelberg

Prof. dr. N.C. Schaper

\section{Co-supervisor}

Dr. K. Meijer

\section{Assessment Committee:}

Prof. dr. R.A. de Bie (chairman)

Prof. dr. M.T. E. Hopman (Radbout University Medical Center Nijmegen)

Prof. dr. T. Hortobágyi (University Medical Center Groningen)

Prof. dr. S. Kremers

Prof. dr. R.J.E.M. Smeets

The research presented in this dissertation was carried out at the Department of Human Movement Sciences, Maastricht University and the Department of Allied Health Professions, Fontys University of Applied Sciences Eindhoven.

The research described in this dissertation was financially supported by the Department of Human Movement Sciences, Maastricht University, and ZonMW.

The reproduction of this dissertation was financially supported by the Maastricht University. 


\section{Table of contents}

\begin{tabular}{|c|c|c|c|}
\hline \multirow[b]{2}{*}{ Chapter } & \multirow[b]{2}{*}{1} & \multirow[b]{2}{*}{ General introduction } & \multirow{2}{*}{$\begin{array}{l}\text { Page } \\
1\end{array}$} \\
\hline & & & \\
\hline Chapter & 2 & $\begin{array}{l}\text { Motor nerve decline does not underlie muscle weakness in diabetic } \\
\text { polyneuropathy }\end{array}$ & 9 \\
\hline Chapter & 3 & $\begin{array}{l}\text { Lower extremity muscle strength is reduced in type } 2 \text { diabetic } \\
\text { patients, with and without polyneuropathy, and is associated with } \\
\text { impaired mobility and reduced quality of life }\end{array}$ & 21 \\
\hline Chapter & 4 & $\begin{array}{l}\text { Resistance training improves plantar flexor strength and walking } \\
\text { speed in people with diabetic polyneuropathy }\end{array}$ & 35 \\
\hline Chapter & 5 & $\begin{array}{l}\text { Training program of the study: resistance training improves plantar } \\
\text { flexor strength and walking speed in people with diabetic } \\
\text { polyneuropathy }\end{array}$ & 51 \\
\hline Chapter & 6 & $\begin{array}{l}\text { The use of physical interventions to improve muscle strength, balance } \\
\text { and mobility in patients with diabetic polyneuropathy; a systematic } \\
\text { review }\end{array}$ & 57 \\
\hline Chapter & 7 & Summery and discussion & 75 \\
\hline Appendix & & Nederlandse samenvatting voor niet ingewijden (Dutch summary) & 87 \\
\hline & & Dankwoord (acknowledgements) & 93 \\
\hline & & Curriculum Vitae \& Publications & 97 \\
\hline
\end{tabular}



Chapter 1

General introduction 


\section{Diabetes mellitus}

Diabetes mellitus is a metabolic disease that is characterized by elevated levels of blood glucose. Already 2000 years ago, the ancient Greek physician Arateus of Cappadocia gave the first complete description of diabetes and concluded that "life with diabetes is short, disgusting and painful". Nowadays, diabetes is a fast growing chronic disease, a worldwide pandemic. Around 366 million people have diabetes mellitus and this number will be a staggering 439 million in 2030 worldwide (1). Also in the Netherlands prospects are not encouraging with a prevalence of almost 0.9 million people in 2011 and an estimated prevalence of more than 1.4 million people in 2025 (2).

There are two distinct types of diabetes mellitus: type 1 (DM1) and type 2 diabetes mellitus (DM2). Ten percent of all patients with diabetes have DM1 which in most (but not all) cases develops during childhood or adolescence. This type of diabetes is the result of an autoimmune destruction of the insulin producing beta cells in the pancreas (3). The vast majority of the patients with diabetes mellitus suffer from DM2. This metabolic disorder is characterized by high blood glucose levels (hyperglycemia) due to insulin resistance and relative lack of insulin.

There are several risk factors in the development of DM2, such as family history (genetic predisposition), intrauterine environment, obesity, diet and physical inactivity $(4,5)$. Since the early eighties diet and physical activity in relation to DM2 get more and more attention. Edward Horton concluded in 1983 in his review that "Environmental factors such as excessive caloric intake...altered dietary composition, physical inactivity...and the process of aging, may contribute to the development of noninsulin-dependent diabetes mellitus in the genetically predisposed subject..." (6).

\section{Diabetic polyneuropathy and its complications}

Diabetes mellitus is often accompanied by numerous co-morbidities. Several of these co-morbidities are directly or indirectly related to elevated blood glucose levels. This change in blood glucose levels can result in changes in large and small blood vessels. Alterations in large blood vessels can contribute to e.g. coronary artery disease, peripheral vascular disease and stroke. Changes in small blood vessels in e.g. the eyes, kidneys and nerves can lead to retinopathy, nephropathy and neuropathy, respectively (7-11). In patients with DM2 additional factors, such as hypertension, obesity, dyslipidaemia and low grade chronic inflammation play a role in the development and progression of these vascular complications. Retinopathy can result in loss of vision, nephropathy in kidney failure and the consequences of nerve damage are very diverse, as different types of nerves in different parts of the body can be affected. Damage to small fibres can result in autonomic failure, 
with e.g. orthostatic hypotension as a consequence, large fibre damage can result in several different types of mononeuropathies and in distal symmetrical polyneuropathy. Diabetic polyneuropathy (DPN) is the probably the most frequent manifestation of nerve damage and is the topic of this dissertation.

DPN is a leading source of morbidity and mortality in patients with diabetes. Twenty to $40 \%$ of all patients with diabetes are diagnosed with DPN and in $10-18 \%$ of the cases patients already have nerve damage at the time diabetes has been diagnosed $(8,12)$. DPN can be classified as small and large fibre neuropathy (13-16). Nerve damage of small fibres can lead to symptoms such as pain, numbness, loss of light touch perception and autonomic impairments such as irregular heart rate and deteriorated blood pressure. Nerve damage of large fibres can result in loss of tendon reflexes, impaired vibration perception, decreased muscle strength and probably also painful symptoms (9, $11,17-24)$.

Nerve dysfunction can be diagnosed with electrophysiological techniques, using electromyography (EMG), but the diagnosis can also be based on clinical examination (25). With EMG, motor and sensory nerve conduction velocity can be studied. This is a relative expensive, time consuming and painful diagnosis. A clinical test procedure, for example the Valk score, is based on a scoring system where the score is determined by examining the Achilles tendon reflex, vibration awareness, sharpblunt discrimination, touch sense, position sense of the hallux and manual assessment of extensor muscle strength of the hallux and flexor muscle strength of the foot in which all items are scored as either normal, impaired or absent. This method is relatively quick, painless and inexpensive.

\section{Muscle strength, mobility and quality of life}

The complaints mentioned, such as painful symptoms and deteriorated muscle strength, will have a large impact on the life of patients with DPN. Muscle dysfunction, e.g. loss of muscle strength and mitochondrial dysfunction, already occurs in patients with DM2 (26-30) and can further deteriorate due to $\operatorname{DPN}(17,26,27)$. It is unclear whether the reduced muscle strength in DM2 patients is directly related to motor and sensory nerve dysfunction. There is a strong association between loss of muscle strength and impaired mobility in patients with $\operatorname{DPN}(8,9,13,17,20,23,24,31)$. Reduced muscle strength in the lower extremities could be an important factor in the loss of mobility. In a community based study, DM2 patients with DPN took, after correction for other factors effecting mobility, almost 30\% steps per day less compared to patients without DPN (14). This limited mobility encloses a broad range of daily activities. Limited mobility can have a large impact on the independence of an 
individual once basic daily activities such as rising from a chair, walking stairs and doing groceries are impaired. In addition, DPN has been associated with depression and social isolation because DPN causes pain. This pain is linked to diminished self-worth as a result of inability to perform social roles $(12,32)$. The loss of independence and inability to perform in social roles will have a negative effect on the HR-QoL. The loss of muscle strength and mobility and the social isolation can negatively influence each other.

\section{Negative spiral}

Patients with DPN are at risk of entering a vicious circle with decreased muscle strength resulting in physical inactivity and inactivity causing a further decrease in muscle strength. This results in a progressive loss of mobility, with both social and medical consequences. This downward spiral of loss in muscle strength and mobility can lead to decreased self-efficacy which will put the HR-QoL even further under pressure (33) (fig. 1).

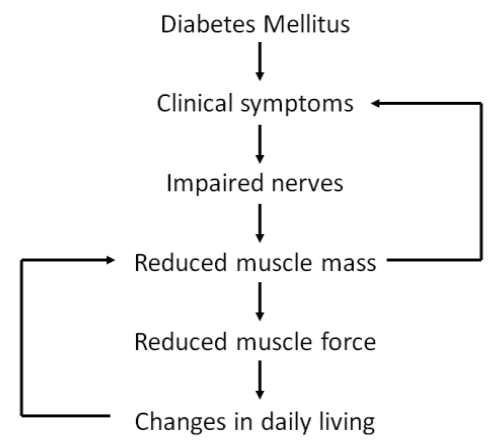

Fig 1: patients with DPN enter a negative spiral

Currently there is no causal treatment for patients with DPN. There is no evidence that for example glycaemic control can counter balance nerve deterioration caused by DPN (34). Most of the current therapies are based on symptom control, such as pain relief using pharmacotherapy (8). Functional, physical improvement like improving mobility is hardly considered. New strategies, such as functional strength and mobility training, are opportunities to break through the mentioned negative spiral and to improve muscle strength, mobility and HR-QoL in patients with DPN. As in DPN the muscles of the (lower) leg are affected in particular, a resistance training program should be focussed on improving 
lower extremity function and should be directly related to daily activities to improve mobility most advantageously (35).

\section{Aim and hypotheses}

The aim of this dissertation is to evaluate the effects of functional resistance and mobility training on lower limb muscle strength, mobility and HR-QoL in DM2 patients with DPN.

The following hypotheses are tested in patients with DM2:

1. A clinical diagnoses of DPN (developed by Valk and colleagues(25)) is a reliable as well as an easy, fast and inexpensive method to examine patients with DM2 compared to an electrophysiological evaluation (chapter 2).

2. The effect of the diabetic state per se is associated negatively with lower extremity muscle strength, mobility and HR-QoL (chapter 2 and 3 ).

3. Diabetic patients without clinically diagnosed DPN have early loss of nerve function that causes loss of muscle strength when compared to healthy persons (chapter 2).

4. DPN is associated with a further loss of lower extremity muscle strength, mobility and HRQoL (chapter 2 and 3).

5. A lower extremity training program will lead to improved lower limb muscle strength, mobility and HR-QoL in patients with DPN (chapter 4, 5 and 6).

\section{Outline of the dissertation}

As mentioned above, in this dissertation DPN is identified by a standardised clinical neurological examination: the Valk score $(25,36)$. However, Dyck et al $(37)$, showed that clinical diagnosis of DPN can be variable and inaccurate. To evaluate the reliability of the Valk score it will be compared to an objective determination of sensory en motor nerve function using electromyography. In addition, decreased muscle strength is associated with diabetes but also with the severity of DPN. It is unclear whether the reduced muscle strength in patients with DM2 is caused by motor and sensory nerve dysfunction. The comparison between the clinical analysis of the nerve function and electromyography as well as the possible correlation between deteriorated motor nerve function and decreased muscle strength in patients with DM2 and with or without DPN will be described in chapter 2 . In chapter 3 we will provide insight in the deterioration of muscle strength, mobility and 
HR-QoL in patients with DPN and patients with DM2 but without DPN and we will compare these patients with healthy age-matched elderly. In chapter 4 a randomized clinical trial of 52 weeks describes the effects of a specific 24 week strength and mobility training program on muscle strength, mobility and HR-QoL and a half year follow up. An intervention and control group of patients with DPN will be compared at baseline, after 12 weeks, after 24 weeks and after half a year follow up (one year after baseline). In chapter 5 the training program that will be given to the subjects with DPN in the intervention group will be described. The subjects who are assigned to the intervention will receive weekly plenary training and home exercises for 24 weeks. Chapter 6 is a systematic review on the optimal training program for patients with DPN to improve muscle strength and/or mobility. In the last 5 years there has been an increasing interest in training patients with DPN. Therefore, we will summarize results from existing studies to provide recommendations how mobility might be improved in subject with DPN based on the current evidence. Chapter 7, the summary and general discussion, integrates all findings of the above described studies and discusses the recommendations based on the strength and limitations of the observations. 


\section{References}

1. Shaw JE, Sicree RA, Zimmet PZ. Global estimates of the prevalence of diabetes for 2010 and 2030. Diabetes Res Clin Pract. 2010 Jan;87(1):4-14.

2. ; Available from: <http://www.diabetesfederatie.nl/ndf-dossiers/ndf-dossier-diabetes-encijfers>.

3. Report of the expert committee on the diagnosis and classification of diabetes mellitus. Diabetes Care. 2003 Jan;26 Suppl 1:S5-20.

4. Zimmet PZ, Magliano DJ, Herman WH, Shaw JE. Diabetes: a 21st century challenge. Lancet Diabetes Endocrinol. 2014 Jan;2(1):56-64.

5. Tuomi T, Santoro N, Caprio S, Cai M, Weng J, Groop L. The many faces of diabetes: a disease with increasing heterogeneity. Lancet. 2014 Mar 22;383(9922):1084-94.

6. Horton ES. Role of environmental factors in the development of noninsulin-dependent diabetes mellitus. Am J Med. 1983 Nov 30;75(5B):32-40.

7. Rosenberg NR, Portegies P, de Visser M, Vermeulen M. Diagnostic investigation of patients with chronic polyneuropathy: evaluation of a clinical guideline. J Neurol Neurosurg Psychiatry. 2001 Aug;71(2):205-9.

8. Basic-Kes V, Zavoreo I, Rotim K, Bornstein N, Rundek T, Demarin V. Recommendations for diabetic polyneuropathy treatment. Acta Clin Croat. 2011 Jun;50(2):289-302.

9. Bokan V. Muscle weakness and other late complications of diabetic polyneuropathy. Acta Clin Croat. 2011 Sep;50(3):351-5.

10. Galer BS, Gianas A, Jensen MP. Painful diabetic polyneuropathy: epidemiology, pain description, and quality of life. Diabetes Res Clin Pract. 2000 Feb;47(2):123-8.

11. Pasnoor M, Dimachkie MM, Barohn RJ. Diabetic neuropathy part 2: proximal and asymmetric phenotypes. Neurol Clin. 2013 May;31(2):447-62.

12. Davies M, Brophy S, Williams R, Taylor A. The prevalence, severity, and impact of painful diabetic peripheral neuropathy in type 2 diabetes. Diabetes Care. $2006 \mathrm{Jul}$;29(7):1518-22.

13. Poncelet AN. Diabetic polyneuropathy. Risk factors, patterns of presentation, diagnosis, and treatment. Geriatrics. 2003 Jun;58(6):16-8, 24-5, 30.

14. van Sloten TT, Savelberg HH, Duimel-Peeters IG, Meijer K, Henry RM, Stehouwer CD, et al. Peripheral neuropathy, decreased muscle strength and obesity are strongly associated with walking in persons with type 2 diabetes without manifest mobility limitations. Diabetes Res Clin Pract. 2010 Oct 19.

15. Kumar S, Ashe HA, Parnell LN, Fernando DJ, Tsigos C, Young RJ, et al. The prevalence of foot ulceration and its correlates in type 2 diabetic patients: a population-based study. Diabet Med. 1994 Jun;11(5):480-4.

16. Cabezas-Cerrato J. The prevalence of clinical diabetic polyneuropathy in Spain: a study in primary care and hospital clinic groups. Neuropathy Spanish Study Group of the Spanish Diabetes Society (SDS). Diabetologia. 1998 Nov;41(11):1263-9.

17. Andreassen CS, Jakobsen J, Andersen H. Muscle weakness: a progressive late complication in diabetic distal symmetric polyneuropathy. Diabetes. 2006 Mar;55(3):806-12.

18. Spallone V, Greco C. Painful and painless diabetic neuropathy: one disease or two? Curr Diab Rep. 2013 Aug;13(4):533-49.

19. Dimitropoulos G, Tahrani AA, Stevens MJ. Cardiac autonomic neuropathy in patients with diabetes mellitus. World J Diabetes. 2014 Feb 15;5(1):17-39.

20. Singleton JR, Smith AG. The diabetic neuropathies: practical and rational therapy. Semin Neurol. 2012 Jul;32(3):196-203.

21. Low PA, Benrud-Larson LM, Sletten DM, Opfer-Gehrking TL, Weigand SD, O'Brien PC, et al. Autonomic symptoms and diabetic neuropathy: a population-based study. Diabetes Care. 2004 Dec;27(12):2942-7.

22. Said G. Diabetic neuropathy--a review. Nat Clin Pract Neurol. 2007 Jun;3(6):331-40. 
23. Andersen H. Motor dysfunction in diabetes. Diabetes Metab Res Rev. 2012 Feb;28 Suppl 1:89-92.

24. Andersen H, Gadeberg PC, Brock B, Jakobsen J. Muscular atrophy in diabetic neuropathy: a stereological magnetic resonance imaging study. Diabetologia. 1997 Sep;40(9):1062-9.

25. Valk GD, de Sonnaville JJ, van Houtum WH, Heine RJ, van Eijk JT, Bouter LM, et al. The assessment of diabetic polyneuropathy in daily clinical practice: reproducibility and validity of Semmes Weinstein monofilaments examination and clinical neurological examination. Muscle Nerve. 1997 Jan;20(1):116-8.

26. Andreassen CS, Jakobsen J, Ringgaard S, Ejskjaer N, Andersen H. Accelerated atrophy of lower leg and foot muscles--a follow-up study of long-term diabetic polyneuropathy using magnetic resonance imaging (MRI). Diabetologia. 2009 Jun;52(6):1182-91.

27. Andersen $\mathrm{H}$, Nielsen $\mathrm{S}$, Mogensen $\mathrm{CE}$, Jakobsen J. Muscle strength in type 2 diabetes. Diabetes. 2004 Jun;53(6):1543-8.

28. Schrauwen P, Schrauwen-Hinderling V, Hoeks J, Hesselink MK. Mitochondrial dysfunction and lipotoxicity. Biochim Biophys Acta. 2010 Mar;1801(3):266-71.

29. Park SW, Goodpaster BH, Strotmeyer ES, de Rekeneire N, Harris TB, Schwartz AV, et al. Decreased muscle strength and quality in older adults with type 2 diabetes: the health, aging, and body composition study. Diabetes. 2006 Jun;55(6):1813-8.

30. Park SW, Goodpaster BH, Strotmeyer ES, Kuller LH, Broudeau R, Kammerer C, et al. Accelerated loss of skeletal muscle strength in older adults with type 2 diabetes: the health, aging, and body composition study. Diabetes Care. 2007 Jun;30(6):1507-12.

31. van Schie CH. Neuropathy: mobility and quality of life. Diabetes Metab Res Rev. 2008 MayJun;24 Suppl 1:S45-51.

32. Vileikyte L, Peyrot M, Gonzalez JS, Rubin RR, Garrow AP, Stickings D, et al. Predictors of depressive symptoms in persons with diabetic peripheral neuropathy: a longitudinal study. Diabetologia. 2009 Jul;52(7):1265-73.

33. van Schie $\mathrm{CH}$, Vermigli C, Carrington AL, Boulton A. Muscle weakness and foot deformities in diabetes: relationship to neuropathy and foot ulceration in caucasian diabetic men. Diabetes Care. 2004 Jul;27(7):1668-73.

34. Bril V. Treatments for diabetic neuropathy. J Peripher Nerv Syst. 2012 May;17 Suppl 2:22-7.

35. Yeom HA, Keller C, Fleury J. Interventions for promoting mobility in community-dwelling older adults. J Am Acad Nurse Pract. 2009 Feb;21(2):95-100.

36. Valk GD, Grootenhuis PA, van Eijk JT, Bouter LM, Bertelsmann FW. Methods for assessing diabetic polyneuropathy: validity and reproducibility of the measurement of sensory symptom severity and nerve function tests. Diabetes Res Clin Pract. 2000 Feb;47(2):87-95.

37. Dyck PJ, Overland CJ, Low PA, Litchy WJ, Davies JL, O'Brien PC, et al. Signs and symptoms versus nerve conduction studies to diagnose diabetic sensorimotor polyneuropathy: $\mathrm{Cl}$ vs. NPhys trial. Muscle Nerve. 2010 Aug;42(2):157-64.

38. Song CH, Petrofsky JS, Lee SW, Lee KJ, Yim JE. Effects of an exercise program on balance and trunk proprioception in older adults with diabetic neuropathies. Diabetes Technol Ther. 2011 Aug;13(8):803-11. 


\section{Chapter 2}

Motor nerve decline does not underlie muscle weakness in diabetic

polyneuropathy

T. Herman IJzerman, Nicolaas C. Schaper, Tom Melai, Paul Blijham, Kenneth. Meijer, Paul J.B. Willems, Hans H.C.M. Savelberg

Muscle Nerve. 2011 Aug; 44(2):241-5 


\section{Abstract}

Type 2 diabetes mellitus (DM2) patients can have decreased muscle strength. This decline can have multiple causes, including diabetic polyneuropathy (DPN). We determined the effect of nerve deterioration on muscle strength in DM2 patients with and without DPN.

Nineteen DM2 patients with DPN (DPN group), 15 DM2 patients without DPN (DC group) and 18 healthy subjects (HC group) were recruited. We determined motor and sensory nerve function of the lower extremity. Isometric dynamometry was performed to determine maximum torque of the ankle joint.

The DPN group had significantly diminished nerve function and muscle strength $(p<0.05)$ compared to both other groups. Only muscle strength was lower in DC subjects compared to HC. No significant correlations were found between nerve functions and muscle strength.

These results indicate that reduced ankle joint torque in DM2 patients with and without DPN is independent of the presence of disturbed nerve function. 


\section{Introduction}

Patients with type 2 diabetes mellitus (DM2) have impaired mobility compared to healthy people (13 ) and decreased muscle strength can be one of the causes of this impairment $(1,4,5)$. This loss of muscle strength in diabetic patients can have multiple causes, including diabetic polyneuropathy (DPN). This is a common complication of diabetes, and it has an estimated prevalence of $20-40 \%$ (6, 7). During the first subclinical stage of the disease, nerve dysfunction can be diagnosed with electrophysiological techniques. In later clinical stages, sensory nerve function and ankle reflexes become disturbed, and the diagnosis is made based on clinical examination. In even more advanced stages of the disease, loss of muscle strength becomes clinically apparent (8). Andersen et al. (9) reported loss of muscle mass and muscle strength of up to $41 \%$ for ankle joint dorsal and plantar flexors in DPN patients.

Previous studies found that decreased muscle strength was associated with diabetes but also with the severity of DPN, based on clinical examination (8). It is unclear whether the reduced muscle strength in DM2 patients is directly related to motor and sensory nerve dysfunction. For the purposes of prevention and intervention, the relation between muscle weakness and DPN in DM2 patients should be clarified. We hypothesized that diabetic patients without clinically diagnosed DPN have early loss of nerve function that causes loss of muscle strength when compared to healthy persons. Furthermore we expected that patients who were clinically diagnosed with DPN have deterioration in muscle strength in comparison with patients who lack clinically diagnosed DPN. To this end, we have measured muscle strength in DM2 patients with and without moderate DPN and compared the results with electrophysiological evaluation of nerve function.

\section{Materials and Methods}

Patients with DM2 were recruited from the diabetes outpatient clinic of the Maastricht University Medical Center and from the Maasland Hospital Sittard. Healthy subjects were recruited from a database that contained healthy volunteers who participated in earlier studies. All subjects were at least 50 years old. Patients were excluded if they were diagnosed with severe cardiac disease, renal insufficiency (creatinine $>180 \mu \mathrm{mol} / \mathrm{l}$ ), cerebrovascular disease, muscular disorders, rheumatoid arthritis, foot ulcers in the last six months prior to the intervention, or nerve damage not due to DPN. All subjects gave informed consent, and the study was approved by the local ethical committee of the Maastricht University Medical Centre. 


\section{Metabolic assessment}

Fasting blood samples were drawn for measurement, using standardized techniques, of plasma glucose, glycated hemoglobin ( $\mathrm{HbA1c}$ ) and creatinine levels. The HbA1c levels were determined as a reflection of their average blood glucose concentration in the previous three months.

\section{Clinical diagnosis}

Patients were clinically diagnosed with DPN using a validated clinical examination developed by Valk and colleagues in which a minimum score of five was required for the diagnosis. This scoring system assesses the sensory modalities, the anatomic level below which light touch sensation is impaired, as well as the muscle strength of the feet and the ankle reflexes (10). Using these modalities, the socalled Valk score can be calculated.

\section{Electrophysiology}

Using a Synergy electromyography (EMG) system (Oxford, United Kingdom) an experienced neurophysiologist carried out electrophysiological measurements according to established standards (11). Temperature of the distal recording sites was kept above 32 degrees Celsius. The following methods were chosen, because these are the most representative nerve conductions in patients with DPN (12). Motor nerve conduction studies included the fibular, tibial, and median nerves. Compound muscle action potential (CMAP) amplitudes, measured from baseline to negative peak and conduction velocities (CV) were obtained from the extensor digitorum brevis, abductor hallucis, and abductor pollicis brevis muscles, respectively. Sensory nerve action potential (SNAP) amplitudes, measured from baseline to negative peak, were obtained by antidromic sensory nerve conduction studies and included the sural nerve and the median nerve to the 2 nd digit. For purpose of evaluation, SNAPs were dichotomized as normal (amplitude $\geq 3.5$ microvolt) or abnormal (amplitude $<3.5$ microvolt or absent).

As mentioned above, DPN was classified by the Valk score, a clinical test procedure. Dyck et al (12), showed that clinical diagnosis of DPN can be variable and inaccurate. Therefore, both the clinical examinations and electrophysiological studies were performed independently by two physicians.

\section{Isometric muscle strength}

We expected that the earliest perceptible loss of muscle strength will be around the ankle joint, i.e. the plantar and dorsal flexors, because nerve deterioration in DPN patients progresses from distal to proximal.

A dynamometer (Cybex II; CMSI, Stoughton, MA) was used to determine isometric muscle strength of dorsal and plantar flexors of the ankle, which are innervated by the fibular and tibial nerves, 
respectively. To determine the maximum voluntary ankle joint moments, the participants were positioned in $90^{\circ}$ hip and knee flexion. The subject's ankle joint center was aligned with the rotation center of the dynamometer. The dorsal and plantar ankle joint moments were determined at five different angles: maximum dorsal flexion, $90^{\circ}, 110^{\circ}, 130^{\circ}$ and maximum plantar flexion. One single maximum voluntary contraction was maintained approximately three seconds. To avoid differences in effort between subjects as much as possible, every maximum voluntary contraction was orally supported by the same researcher. Between subsequent contractions, subjects were allowed two minutes of rest. Passive ankle joint moments were measured one second before the contraction. This passive moment resulted from the mass of the foot, the tension of passive structures and the mass of the arm of the dynamometer. Depending on the joint angle, the passive moment could be in the dorsal or plantar flexion direction. The recorded maximum moments were corrected for these passive moments.

\section{Data processing}

To determine the maximum muscle strength as function of joint angle, a second degree polynomial function was fitted to the maximum isometric strength values at the five joint angles. The highest value of this fitted polynomial was considered the maximum isometric muscle strength. All measurements were performed in the right leg. To compare between the three sub-groups, strength output was normalized for body mass.

\section{Statistical analysis}

Results are presented as mean \pm standard deviation. Analysis of covariance was performed for detection of muscle strength differences between the three experimental groups, with age and gender as covariates. The Bonferroni correction was used post-hoc to correct for multiple testing. For the analysis of the SNAPs we used binary logistic regression analysis. Correlations between absolute muscle strength and CMAP-amplitudes were calculated for all three groups using Pearson correlation. A p-value of $<0.05$ was considered to be significant. Statistical analyses were performed using SPSS 15.0 (SPSS Inc. Chicago IL, USA.)

\section{Results}

We included 19 patients with DPN (mean age $70 \pm 8$ years) and compared them with 15 DM2 patients without DPN (the DC group, $64 \pm 6$ years) and 18 healthy elderly (the HC group, $68 \pm 5$ years). As shown in table 1 the DC group was significantly younger than the DPN group $(p<0.05)$. By 
design, blood glucose levels and HbA1c were significantly higher in the DC and DPN group as compared to the controls (table 1), and DC and DPN subjects had a higher body mass and body mass index (BMI) than control subjects.

EMG and clinical testing resulted in the same diagnosis of DPN in our DM2 patients. This was consistent with the findings of Meijer et al (13), who also showed that clinical tests can differentiate between subjects with and without DPN.

In the DPN group, the values of the electrophysiologic parameters were significantly lower (i.e. worse) as compared to both other groups (table 1). Mean CMAP-amplitude and mean CVs of the fibular and tibial nerves were significantly lower $(p<0.05)$ in the DPN group as compared to the other groups. Furthermore, SNAP amplitudes were significantly more often $(p<0.001)$ absent or decreased in the DPN group, confirming the nerve deterioration in DPN patients.

The corrected muscle strength data differed from the electrophysiologic data in showing a gradual decrease in isometric strength of plantar and dorsal flexors over the three groups (table 1). The DC tended to have decreased plantar flexion muscle strength compared to the HC group; the DPN group had lower muscle strength than the DC group $(p<0.05)$. This finding was substantiated by our observation that maximum dorsal flexion muscle strength showed a similar significant progressive reduction between the HC, DC and DPN subjects $(p<0.05)$.

\begin{tabular}{l|l|l|l} 
Table 1: demographic, blood, nerve and muscle strength characteristics. & & & \\
Parameter & HC & DC & DPN \\
\hline Sex (male/female) & $14 / 4$ & $8 / 7$ & $18 / 1$ \\
\hline Age (years) & $68( \pm 15)$ & $64( \pm 15)$ & $70( \pm 15)^{\#}$ \\
\hline Height $(\mathrm{m})$ & $1.73( \pm 0.07)$ & $1.70( \pm 0.09)$ & $1.72( \pm 0.08)$ \\
\hline Body mass $(\mathrm{kg})$ & $72( \pm 9)$ & $89( \pm 15)^{*}$ & $88( \pm 16)^{*}$ \\
\hline BMI $\left(\mathrm{kg} / \mathrm{m}^{2}\right)$ & $24.4( \pm 2.0)$ & $31.4( \pm 7.0)^{*}$ & $29.4( \pm 5.3)^{*}$ \\
\hline Fasting blood glucose $(\mathrm{mmol} / \mathrm{L})$ & $5.6( \pm 0.6)$ & $8.3( \pm 2.1)^{*}$ & $8.3( \pm 1.7)^{*}$ \\
\hline HbA1c $(\%)$ & $6.0( \pm 0.5)$ & $7.6( \pm 1.0)^{*}$ & $7.2( \pm 1.0)^{*}$ \\
\hline Creatinin $(\mu \mathrm{mol} / \mathrm{L})$ & $89( \pm 13)$ & $81( \pm 15)$ & $96( \pm 24)$ \\
\hline Valk-score & $1.3( \pm 1.4)$ & $2.3( \pm 1.4)$ & $11.3( \pm 4.4)^{* \#}$ \\
\hline CMAP n. peroneus $(\mathrm{mV})$ & $3.7( \pm 2.0)$ & $3.7( \pm 1.4)$ & $2.3( \pm 1.8)^{* \#}$ \\
\hline CMAP n. tibialis $(\mathrm{mV})$ & $8.0( \pm 4.1)$ & $8.8( \pm 4.8)$ & $4.4( \pm 3.7)^{* \#}$ \\
\hline CV n. peroneus $(\mathrm{m} / \mathrm{s})$ & $44.3( \pm 3.5)$ & $44.4( \pm 5.8)$ & $40.1( \pm 4.5)^{* \#}$ \\
\hline CV n. tibialis $(\mathrm{m} / \mathrm{s})$ & $44.0( \pm 4.7)$ & $43.8( \pm 5.2)$ & $38.0( \pm 5.5)^{* \#}$ \\
\hline SNAP n. suralis $(\%)$ & 16 & 20 & $68^{* \#}$ \\
\hline Max plant flex $(\mathrm{Nm} / \mathrm{kg})$ & $0.93( \pm 0.26)$ & $0.70( \pm 0.28)$ & $0.54( \pm 0.28)^{*}$ \\
\hline Max dors flex(Nm/kg) & $0.62( \pm 0.11)$ & $0.52( \pm 0.11)^{*}$ & $0.40( \pm 0.11)^{* \#}$
\end{tabular}

Notes: BMI, body mass index; HbA1c, haemoglobin A1c; CMAP, compound muscle action potential; CV, conduction velocity; SNAP, sensory nerve action potential; Max plant flex, maximal plantar flexion; Max dors flex, maximal dorsal flexion. Muscle strength was corrected for body mass.

* $p<0.05$ compared with $\mathrm{HC} \# \mathrm{p}<0.05$ compared with DC. 
We did not find any significant correlation between the absolute maximum voluntary strength output of the plantar and dorsal flexors and the amplitudes CMAPs of the tibial and fibular nerves, respectively (fig 1 ) or any other neurophysiological parameter.

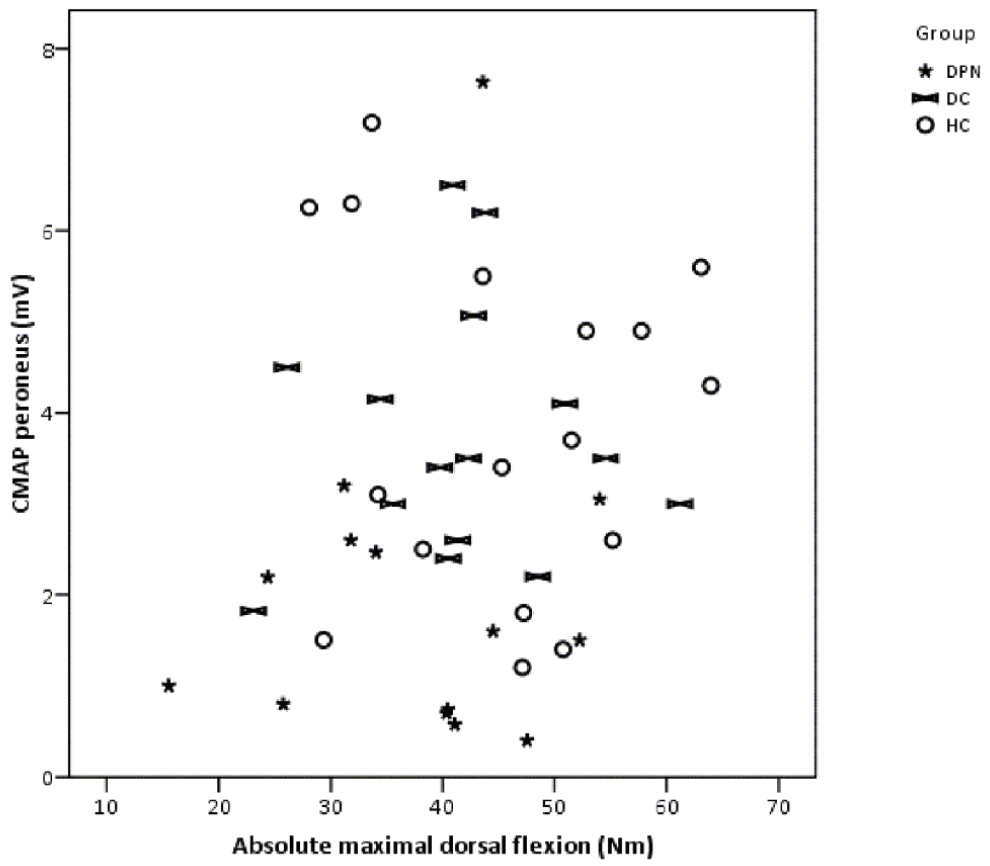

Fig 1: Example of a relationship between motor nerve function and muscle strength.

\section{Discussion}

We hypothesized that loss of muscle strength in DM2 patients without clinically diagnosed DPN is due to early nerve damage and that patients with clinically diagnosed DPN show increased muscle weakness when compared to diabetic subjects without clinically diagnosed DPN due to an increased deterioration of the motor nerve system. Intriguingly, the data obtained in this study is not in line with this hypothesis. The loss of maximum voluntary muscle strength appears to develop independently from loss of motor nerve or sensory nerve function in DM2 patients with and without DPN.

Three important findings emerged from our study. Firstly, the DPN group displayed smaller CMAPs, suggesting a smaller amount of activated muscle mass than both other groups. Secondly, the CV was reduced in the DPN group, indicating a deterioration in nerve function. Thirdly, relative muscle 
strength was lower in the DC group than in the HC group. The DPN group, in turn, possessed substantially lower muscle strength than the DC group.

Muscle strength is determined by the product of the amount of activated muscle mass and muscle quality. Loss of muscle mass is a frequently observed complication in diabetic patients, and usually muscle mass reduction is accompanied by reduced strength (5). The magnitude of the CMAP is determined by the mass of the activated muscle. The lower the CMAP the lower the activated muscle mass. In the group of DM2 patients without DPN, CMAP amplitudes were comparable to the controls and to normal values. However, our group of DPN patients had decreased SNAP and CMAP values. The pattern of reduced or absent SNAPs and CMAPs with only moderately reduced conduction velocities is typical for axonal loss in polyneuropathy and is in concordance with previous reports of DPN (14). Nevertheless, no significant correlations between the different electrophysiologically determined nerve functions and different absolute muscle strength measurements were found. Therefore, loss of nerve function and decreased innervation does not seem to be the major factor that explains the differences in muscle strength between patients with and without DPN compared to the healthy controls. Taking once more into account that muscle strength is the product of the amount of activated muscle mass and muscle quality, the amount of activated muscle mass of our group of subjects seems not to be the limiting factor, as no relationship was observed between the CMAPs and muscle strength. Differences in muscle quality seem to be the most likely factor responsible for the differences in relative muscle strength between the three groups of our study. This conclusion is in line with an earlier study of Park et.al. (4), who observed that muscle quality, determined by the ratio of the muscle strength to extremity mass, was significantly lower in subjects with type 2 diabetes than in those without diabetes in the upper and lower extremities.

Several steps in the process from nerve conduction to muscle strength generation may be disturbed and can be of influence on muscle quality in DM2 patients. Muscle quality is the maximum voluntary contractile torque per unit regional muscle mass, and there is an electrical signal as well as a mechanical component needed to contract a muscle fiber. Na+/K+ ATPase plays a key role in the electrical signal pathway. Phielix et al (15) showed that in vivo mitochondrial dysfunction in DM2 patients was accompanied by lower ADP-driven mitochondrial respiration. Moreover, these patients have smaller subsarcolemmal mitochondria (16) and these mitochondria are essential in the energy supply of the $\mathrm{Na}+\mathrm{K}+$ ATPase. In addition, Kuwabara et al (17) and Kitano et al (18) showed that hyperglycemia can result in decreased $\mathrm{Na}+\mathrm{K}+$ ATPase activity and diminished nerve excitability.

The mechanical component can be influenced by increased glycation of skeletal muscle myosin. Ramamurthy (19) showed that glycation of myosin leads to significant reduction of the in vitro motility speed, and cross linking of glycated myosin can change both functional and structural 
properties of this protein. If either or both electrical and mechanical components are disturbed, muscle contraction will not be optimal.

Our study has some limitations. Not all motor units are activated during a maximum voluntary contraction. In addition, it has been shown that people with chronic diseases have significantly lower muscle activation than healthy control subjects (20). It might be that diabetic patients with or without DPN have lower voluntary muscle activation than healthy subjects during a maximum voluntary contraction. However, as far as we know, no research in this subpopulation has been performed in this field so far. Furthermore, we did not perform needle EMG in our study group. In the DNP patients, the polyneuropathy is probably accompanied by neurogenic motor unit remodelling. In the DM2 patients, such remodelling would not likely have occurred, considering the normal nerve conduction parameters that we found. We cannot exclude, however, that concomitant myopathic changes may have played a part in loss of strength. Finally, we did not perform autonomic function tests in our study population. A relatively small percentage (14\%) of diabetic patients suffer from moderate to severe autonomic failure (21). However, to our knowledge there are no indications in the current literature that autonomic dysfunction itself will influence maximum muscle strength.

In conclusion, we have shown that reduced muscle strength in DM2 patients with and without DPN is independent of the presence of disturbed nerve function. It is unlikely that this reduction of muscle strength is due to a decreased amount of activated muscle mass. Rather, the results suggest a deterioration in muscle quality in DM2 and DPN patients. The surplus of muscle strength loss in patients with DPN compared to DM2 patients can be caused by deterioration of muscle quality. The causes of the loss of muscle quality leading to decreased muscle strength in diabetic patients should be the main focus for future research. By performing muscle biopsies for histopathological analysis in these studies, more fundamental insight into the changes of muscle quality in diabetes can be obtained. 


\section{References}

1. Orr R, Tsang T, Lam P, Comino E, Singh MF. Mobility impairment in type 2 diabetes: association with muscle power and effect of Tai Chi intervention. Diabetes Care. 2006 Sep;29(9):2120-2.

2. Volpato S, Ferrucci L, Blaum C, Ostir G, Cappola A, Fried LP, et al. Progression of lowerextremity disability in older women with diabetes: the Women's Health and Aging Study. Diabetes Care. 2003 Jan;26(1):70-5.

3. Maty SC, Fried LP, Volpato S, Williamson J, Brancati FL, Blaum CS. Patterns of disability related to diabetes mellitus in older women. J Gerontol A Biol Sci Med Sci. 2004 Feb;59(2):148-53.

4. Park SW, Goodpaster BH, Strotmeyer ES, de Rekeneire N, Harris TB, Schwartz AV, et al. Decreased muscle strength and quality in older adults with type 2 diabetes: the health, aging, and body composition study. Diabetes. 2006 Jun;55(6):1813-8.

5. Park SW, Goodpaster BH, Strotmeyer ES, Kuller LH, Broudeau R, Kammerer C, et al. Accelerated loss of skeletal muscle strength in older adults with type 2 diabetes: the health, aging, and body composition study. Diabetes Care. 2007 Jun;30(6):1507-12.

6. Kumar S, Ashe HA, Parnell LN, Fernando DJ, Tsigos C, Young RJ, et al. The prevalence of foot ulceration and its correlates in type 2 diabetic patients: a population-based study. Diabet Med. 1994 Jun;11(5):480-4.

7. Cabezas-Cerrato J. The prevalence of clinical diabetic polyneuropathy in Spain: a study in primary care and hospital clinic groups. Neuropathy Spanish Study Group of the Spanish Diabetes Society (SDS). Diabetologia. 1998 Nov;41(11):1263-9.

8. Andreassen CS, Jakobsen J, Andersen H. Muscle weakness: a progressive late complication in diabetic distal symmetric polyneuropathy. Diabetes. 2006 Mar;55(3):806-12.

9. Andersen H, Gadeberg PC, Brock B, Jakobsen J. Muscular atrophy in diabetic neuropathy: a stereological magnetic resonance imaging study. Diabetologia. 1997 Sep;40(9):1062-9.

10. Valk GD, de Sonnaville JJ, van Houtum WH, Heine RJ, van Eijk JT, Bouter LM, et al. The assessment of diabetic polyneuropathy in daily clinical practice: reproducibility and validity of Semmes Weinstein monofilaments examination and clinical neurological examination. Muscle Nerve. 1997 Jan;20(1):116-8.

11. Dumitru D, Amato A, Zwarts M. Electrodiagnostic Medicine. 2002(2).

12. Dyck PJ, Overland CJ, Low PA, Litchy WJ, Davies JL, Dyck PJ, et al. Signs and symptoms versus nerve conduction studies to diagnose diabetic sensorimotor polyneuropathy: $\mathrm{Cl}$ vs. NPhys trial. Muscle Nerve. Aug;42(2):157-64.

13. Meijer JW, Bosma E, Lefrandt JD, Links TP, Smit AJ, Stewart RE, et al. Clinical diagnosis of diabetic polyneuropathy with the diabetic neuropathy symptom and diabetic neuropathy examination scores. Diabetes Care. 2003 Mar;26(3):697-701.

14. Kiziltan ME, Gunduz A, Kiziltan G, Akalin MA, Uzun N. Peripheral neuropathy in patients with diabetic foot ulcers: clinical and nerve conduction study. J Neurol Sci. 2007 Jul 15;258(1-2):75-9.

15. Phielix E, Schrauwen-Hinderling VB, Mensink M, Lenaers E, Meex R, Hoeks J, et al. Lower intrinsic ADP-stimulated mitochondrial respiration underlies in vivo mitochondrial dysfunction in muscle of male type 2 diabetic patients. Diabetes. 2008 Nov;57(11):2943-9.

16. Kelley DE, He J, Menshikova EV, Ritov VB. Dysfunction of mitochondria in human skeletal muscle in type 2 diabetes. Diabetes. 2002 Oct;51(10):2944-50.

17. Kuwabara S, Ogawara K, Hattori T, Suzuki Y, Hashimoto N. The acute effects of glycemic control on axonal excitability in human diabetic nerves. Internal Medicine. 2002 january 16;41:360-5.

18. Kitano $Y$, Kuwabara S, Misawa S, Ogawara K, Kanai K, Kikkawa Y, et al. The acute effects of glycemic control on axonal excitability in human diabetics. Ann Neurol. 2004 Oct;56(4):462-7.

19. Ramamurthy $B$, Hook $P$, Jones $A D$, Larsson $L$. Changes in myosin structure and function in response to glycation. Faseb J. 2001 Nov;15(13):2415-22. 
20. Vivodtzev I, Flore P, Levy P, Wuyam B. Voluntary activation during knee extensions in severely deconditioned patients with chronic obstructive pulmonary disease: benefit of endurance training. Muscle Nerve. 2008 Jan;37(1):27-35.

21. Low PA, Benrud-Larson LM, Sletten DM, Opfer-Gehrking TL, Weigand SD, O'Brien PC, et al. Autonomic symptoms and diabetic neuropathy: a population-based study. Diabetes Care. 2004 Dec;27(12):2942-7. 


\section{Chapter 3}

Lower extremity muscle strength is reduced in type 2 diabetic patients, with and without polyneuropathy, and is associated with impaired mobility and reduced quality of life

T. Herman IJzerman, Nicolaas C. Schaper, Tom Melai, Kenneth. Meijer, Paul J.B. Willems, Hans H.C.M. Savelberg

Diabetes Res. Clin. Pract. 2012 Mar;95(3):345-51 


\begin{abstract}
Earlier studies have shown that more than $50 \%$ of the patients with diabetes mellitus type 2 (DM2) have impaired mobility resulting in decreased health related quality of life (HR-QoL). Diabetic polyneuropathy (DPN) has been suggested as an important factor in mobility loss. The purpose of the present study was to distinguish the effects of both DM2 and DPN on mobility, muscle strength and HR-QoL.

DPN patients ( $n=98)$, DM2 patients without DPN (DC) ( $n=39)$ and healthy subjects (HC) $(n=19)$ performed isometric and isokinetic lower limb muscle strength tests. Mobility was determined by a timed up and go test (TUGT), a six minute walk test and the physical activity scale for the elderly questionnaire. HR-QoL was determined by the SF36 questionnaire.

DPN patients had moderate polyneuropathy. In both DPN and DC patients lower leg muscle strength was reduced by $30-50 \%$ compared to HC. Muscle strength was correlated with the mobility tests, and reduced muscle strength as well as impaired mobility were associated with a loss of HR-Qol (all $\mathrm{p}<0.05$ ). We did not observe major differences in muscle strength, mobility (except for the TUGT, $p<0.01)$ and HR-QoL between the diabetic patients with and without DPN.

DM2 patients with and without DPN have decreased maximal muscle strength of the plantar and dorsal flexors of the ankle joint and of the extensors and flexors of the knee joint and impaired mobility. These abnormalities are associated with a loss of HR-QoL. The additional effect of moderate DPN was small in our patients.
\end{abstract}




\section{Introduction}

Diabetes type 2 (DM2) is accompanied by a wide range of impairments and several studies have shown that DM2 is associated with a loss of mobility (1-4). This limited mobility encloses a broad range of daily activities. Limited mobility can have a large impact on the independence of an individual once basic daily activities such as rising from a chair, walking stairs and doing groceries are impaired. Reduced muscle strength could be an important factor in this mobility loss and Andersen et al. (5) showed in an earlier study that DM2 is associated with loss of muscle strength around the ankle and knee joint. The loss of mobility and muscle strength of the lower extremities can enhance each other. Inactivity will lead to loss of muscle mass, resulting in decreased muscle strength and vice versa increased muscle weakness will lead to an increased effort to be physical active. This will result in a negative spiral of become less active, losing muscle strength, loss of independence and health related quality of life (HR-QoL) (6).

Several factors could be responsible for the limited mobility and decreased muscle strength in diabetic patients such as intrinsic abnormalities in diabetic muscle, impaired capillary recruitment, peripheral arterial disease and diabetic polyneuropathy (DPN) $(5,7,8)$. DPN occurs in approximately $20-40 \%$ of all diabetic patients $(9,10)$. Furthermore, neuropathy has been associated with impaired mobility, loss of muscle strength and decreased HR-QoL, as reviewed elsewhere (7). Earlier studies found that patients with severe DPN have increased muscle weakness in lower extremities $(5,11)$. However, several studies have shown that diabetic patients without DPN also have decreased muscle strength and volume compared to healthy subjects $(5,12,13)$. The contribution of polyneuropathy to the limited mobility and reduced and reduced muscle strength is therefore still matter for debate. In a recent accelerometer study we found that DPN and handgrip strength were each independently associated with an approximately 30\% reduction in the daily number of steps/day during a 1 week period (14). However, the role of impaired lower extremity muscle strength in the loss of mobility and QoL in DM2 patients with and without DPN remains unclear. Therefore, the aim of this study was to determine the effect of the diabetic state per se and of DPN on lower extremity muscle function, mobility and health-related $\mathrm{QoL}(\mathrm{HR}-\mathrm{Qol})$. Furthermore, the relations between these primary outcome parameters were assessed.

\section{Materials and Methods}

\section{Subjects}


Patients with DM2 (DC group) and DPN (DPN group) were recruited in one university and four district hospitals in the south of the Netherlands. Healthy subjects (HC group) were recruited from a database that contained healthy volunteers who participated in earlier studies. All subjects were at least 50 years and were excluded if diagnosed with severe cardiac disease, renal insufficiency (creatinin > $180 \mu \mathrm{mol} / \mathrm{I}$ ), intermittent claudication, muscular disorders or rheumatoid arthritis. In addition, DM2 patients were excluded if they had been diagnosed with foot ulcers in the last six months prior to the study, or had nerve damage not due to DPN. Written informed consent was obtained from all participants and the protocol was approved by the medical ethical committee of the Maastricht University Medical Centre.

\section{Clinical assessment of polyneuropathy}

Peripheral polyneuropathy was diagnosed and classified based on a standardised clinical neurological examination (CNE) in which a CNE score $\geq 5$ indicates the presence of peripheral neuropathy and a score of $\geq 15$ is considered as severe DPN (15). In short, the CNE score is determined by examining the Achilles tendon reflex, vibration awareness, sharp-blunt discrimination, touch sense, position sense of the hallux and manual assessment of extensor muscle strength of the hallux and flexor muscle strength of the foot in which all items are scored as either normal, impaired or absent (0-2 points). In addition, the scoring of light touch sense was related to the anatomical level below which it is impaired (toe, mid-foot, ankle, mid-calf and knee) (0-5 points). In an earlier study of our group, were a sub population of the current population was studied, EMG and CNE score resulted in the same diagnosis of DPN in our DM2 patients (16).

\section{Isometric and isokinetic muscle strength}

Two dynamometers, the Cybex II (CMSI, Stoughton, MA) and the Biodex System 3 (Biodex Medical Systems, New York), were used to determine isometric and isokinetic muscle strength of dorsal and plantar flexor muscles of the ankle joint and the extensor and flexor muscles of the knee joint. Both systems are frequently used in scientific studies and both dynamometers are validated systems. According Gosker et al. (17) both systems yield similar results. Half of all subjects were tested on the Biodex and half on the Cybex.

Isometric test 
To determine maximal, voluntary ankle joint moments, participants were positioned in a $90^{\circ}$ hip and knee flexion. The subject's ankle joint centre was aligned with the rotation centre of the dynamometer. The dorsal and plantar ankle joint moments were determined at four different angles; 800, 900, 1050 and 1200, where 800 equals maximal dorsal flexion and 1200 compares maximal plantar flexion. One single maximal voluntary contraction was maintained approximately 3 seconds. Between subsequent contractions subjects were allowed 2 minutes of rest. Passive ankle joint moments were measured one second before the contraction. This passive moment resulted from the weight of the foot, the tension of passive structures and the weight of the arm of the dynamometer. Depending on the joint angle, the passive moment could be in dorsal or plantar flexion direction. The recorded maximal moments were corrected for these passive moments. A similar protocol was used to determine maximal voluntary muscle strength for the knee joint flexors and extensors. Subjects were positioned in a $90^{\circ}$ hip flexion. Maximal voluntary knee joint moments were assessed at five angles: 300, 500, 700, 900 and 1000, where 00 represented a fully extended leg. All measurements were performed in the right leg.

Maximal strength was determined by fitting a second degree polynomial function to the joint moment data at subsequent joint angles. The highest value of this fitted polynomial was considered the maximal strength. All joint moments were normalized for body mass (16).

Isokinetic test

The subjects were positioned the same as during the isometric tests. The participants were asked to push and pull as hard and fast as possible over their maximal range of motion with verbal encouragement of the researcher. The joint angular velocity was set on $120 \%$ s. Subjects performed 20 repetitions. The work of each of these plantar and dorsal flexion repetitions of the ankle and extension and flexion repetitions of the knee was calculated and expressed as $\mathrm{Nm} / \mathrm{kg}$. To determine the fatiguability of the involved muscle groups an adapted formula of Moreau et al. was used (18). For ankle dorsal and plantar flexion and for knee extension and flexion, the fatigue index (FI) was calculated as the ratio of the mean work of the 16th till 20th repetition over the mean work of the highest, five consecutive repetitions within the first eight repetitions. A FI approaching 100\% indicates that work decline during the test is low. Results of muscle fatiguability were considered as missing if the highest consecutive five repetitions were not performed within the first eight repetitions.

Mobility 
Three validated tests were used to assess mobility. In the six minute walk test (6MWT) subjects were asked to walk as far as possible within six minutes without running on a 220 meter flat track; in the timed up and go test (TUGT) subjects were asked to stand up from a chair, walk three meters at comfortable speed, turn, walk back and sit down again. The Physical Activity Scale of the Elderly (PASE) questionnaire was used to determine the daily activity pattern. The higher the score at the PASE questionnaire the more active a subject is in daily life.

\section{Quality of life}

The SF36 questionnaire was used to determine HR-QoL. This questionnaire contains 36 items. It measures health on nine multi item dimensions, based on functional status, well being and overall evaluation of health (19). The higher the score at the SF36, the more positive a subject was about experienced HR-QoL .

\section{Biochemical analysis}

Overnight fasting blood samples were drawn for measurement of glucose, glycated hemoglobin (HbA1c) and creatinine.

\section{Statistical analysis}

Results are presented as mean \pm standard deviation. Analysis of variance was performed to detect differences between the three experimental groups. We used analysis of covariance to test differences between groups in the muscle strength, mobility and QoL data; age and gender were entered as covariates. If main effects were significant, the Bonferroni test was used for post hoc analysis. Pearson's correlation coefficients were calculated between muscle function (muscle strength and fatiguability), the three mobility tests and the nine QoL items. Within the group of DPN patients, correlations between the level of nerve damage (CNE score) and maximal muscle strength, mobility and QoL were evaluated. A p-value of $<0.05$ was considered as significant.

\section{Results}

We included 98 DM2 participants with DPN, 39 DM2 patients without DPN and 19 healthy control subjects. Demographic, neurological and blood parameters are presented in Table 1. In general, we 
included elderly obese diabetic subjects with good to moderate blood glucose control. The DC group was 5 years younger than the HC group $(p<0.01)$. Height and creatinine were higher in the DPN group than the DC group $(p<0.01)$, whereas weight, $B M I, H b A 1 c$ and glucose were higher in both diabetic groups $(p<0.001)$ compared to the HC group. By definition, the CNE score was higher $(p<0.001)$ in patients with DPN compared to both other groups.

Table 1: demographic, neurological and blood parameters.

\begin{tabular}{l|c|c|c|c} 
& DPN & DC & HC & P-value \\
\hline $\mathrm{N}$ & 98 & 39 & 19 & \\
\hline Sex (male/female) & $80 / 18^{\mathrm{b}}$ & $20 / 19$ & $15 / 4^{\mathrm{b}}$ & 0.001 \\
\hline Age $(\mathrm{yr})$ & $67 \pm 8$ & $62 \pm 7^{\mathrm{a}}$ & $68 \pm 5$ & 0.002 \\
\hline Height $(\mathrm{m})$ & $1.74 \pm 0.08^{\mathrm{b}}$ & $1.68 \pm 0.10$ & $1.72 \pm 0.07$ & 0.002 \\
\hline Weight $(\mathrm{kg})$ & $94 \pm 18^{\mathrm{a}}$ & $88 \pm 15^{\mathrm{a}}$ & $73 \pm 8$ & $<0.001$ \\
\hline BMI $\left(\mathrm{kg} \cdot \mathrm{m}^{2}\right)$ & $30.8 \pm 5.0^{\mathrm{a}}$ & $31.2 \pm 5.7^{\mathrm{a}}$ & $24.4 \pm 1.9$ & $<0.001$ \\
\hline $\mathrm{CNE} \mathrm{score}$ & $13 \pm 5^{\mathrm{ab}}$ & $3 \pm 2$ & $1 \pm 2$ & $<0.001$ \\
\hline $\mathrm{HbA}_{1 \mathrm{c}}(\%)$ & $7.3 \pm 1.1^{\mathrm{a}}$ & $7.1 \pm 1.0^{\mathrm{a}}$ & $6.0 \pm 0.5$ & $<0.001$ \\
\hline Glucose $(\mathrm{mmol} / \mathrm{L})$ & $8.5 \pm 2.3^{\mathrm{a}}$ & $8.0 \pm 2.2^{\mathrm{a}}$ & $5.6 \pm 0.6$ & $<0.001$ \\
\hline Creatinine $(\mu \mathrm{mol} / \mathrm{L})$ & $98 \pm 30^{\mathrm{b}}$ & $81 \pm 22$ & $89 \pm 12$ & 0.004
\end{tabular}

$\mathrm{CNE}=$ clinical neurological examination; P-value: main effect of the analysis of variance between the three groups. a post hoc analysis $p \leq 0.05$ compared to $H C$, b post hoc analysis $p \leq 0.05$ compared to $D C$

\section{Muscle strength and relative fatigue}

Both DPN and DC groups had diminished, maximal, voluntary muscle strength in all parameters measured around the knee and ankle joints compared to the HC group (reductions of 34 to 47\%), whereas no differences were observed between the DPN and DC groups (Figure 1). Although all FI's were numerically lower in both diabetic groups compared to the $H C$ group $(p>0.1)$, this was not statistically significant except for the fatigability of the knee joint flexors. This muscle group had in the DC group a significant lower Fl in comparison to the HC group (Table 2). 


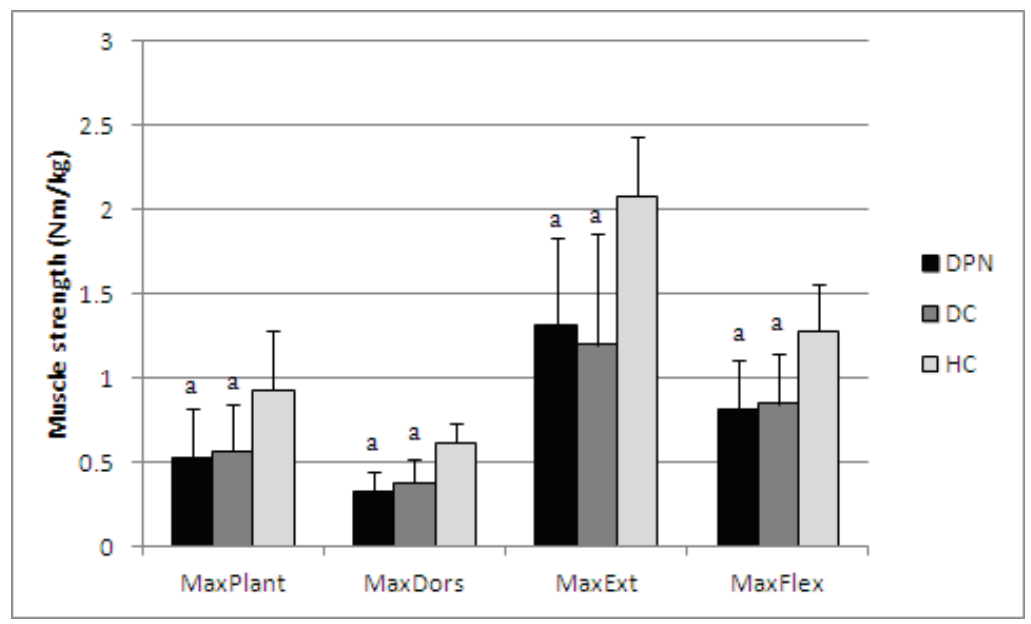

Figure 1: Normalized maximal isometric muscle strength of the plantar flexors (MaxPlant), dorsal flexors (MaxDors), knee extensors (MaxExt) and knee flexors (MaxFlex) (.P-value: main effect of the analysis of variance between the three groups. post hoc analysis $\mathrm{p} \leq 0.001$ compared to $\mathrm{HC}(\mathrm{a})$. Joint moments were normalized for body mass.

Table 2: muscle strength, mobility and QoL parameters

\begin{tabular}{l|c|c|c|c} 
& DPN & DC & HC & P-value \\
\hline FatiquePlant (\%) & $61 \pm 20$ & $57 \pm 14$ & $65 \pm 14$ & 0.315 \\
\hline FatigueDors (\%) & $42 \pm 16$ & $39 \pm 14$ & $47 \pm 14$ & 0.226 \\
\hline FatigueExt (\%) & $63 \pm 13$ & $66 \pm 13$ & $70 \pm 8$ & 0.159 \\
\hline FatigueFlex (\%) & $71 \pm 10$ & $70 \pm 11^{\mathrm{a}}$ & $78 \pm 9$ & 0.039 \\
\hline PASE & $141 \pm 81$ & $151 \pm 91$ & $195 \pm 72$ & 0.06 \\
\hline 6MWT (m) & $477 \pm 89^{\mathrm{a}}$ & $486 \pm 87^{\mathrm{a}}$ & $668 \pm 68$ & $<0.001$ \\
\hline TUGT (s) & $9.3 \pm 2.8^{\mathrm{a}}$ & $8.4 \pm 2.4$ & $7.2 \pm 0.9$ & 0.002 \\
\hline SF36 Physical functioning & $68 \pm 25^{\mathrm{a}}$ & $71 \pm 28^{\mathrm{a}}$ & $91 \pm 11$ & 0.001 \\
\hline SF36 Social functioning & $77 \pm 23^{\mathrm{a}}$ & $75 \pm 28^{\mathrm{a}}$ & $93 \pm 15$ & 0.02 \\
\hline SF36 Role limitations (physical problems) & $66 \pm 39^{\mathrm{a}}$ & $62 \pm 44^{\mathrm{a}}$ & $97 \pm 8$ & 0.003 \\
\hline SF36 Role limitations (emotional problems) & $78 \pm 36$ & $66 \pm 44$ & $91 \pm 27$ & 0.051 \\
\hline SF36 Mental heatlh & $74 \pm 20$ & $71 \pm 17^{\mathrm{a}}$ & $85 \pm 15$ & 0.032 \\
\hline SF36 Vitality & $61 \pm 18^{\mathrm{a}}$ & $60 \pm 20^{\mathrm{a}}$ & $79 \pm 20$ & $<0.001$ \\
\hline SF36 Pain & $71 \pm 24^{\mathrm{a}}$ & $68 \pm 28^{\mathrm{a}}$ & $91 \pm 11$ & 0.003 \\
\hline SF36 General health perception & $50 \pm 20^{\mathrm{a}}$ & $50 \pm 19^{\mathrm{a}}$ & $77 \pm 15$ & $<0.001$ \\
\hline SF36 Health change & $46 \pm 20$ & $51 \pm 25$ & $54 \pm 17$ & 0.197 \\
\hline P-vat
\end{tabular}

P-value: main effect of the analysis of variance between the three groups. a post hoc analysis $p \leq 0.05$ compared to HC. Fatigue index of the plantar flexors (FatiguePlant), dorsal flexors (FatigueDors), knee extensors (FatigueExt) and knee flexors (FatigueFlex).

\section{Mobility}

Both diabetic groups showed a decreased mobility compared to the HC group. During the 6MWT, participants in both diabetic groups walked significantly less far than HC participants (approximately $28 \%$, table 2). The 6MWT distance for DC and DPN did not differ. The PASE score showed a similar, but no significant trend $(p=0.06)$ with HC participants reporting more daily physical activity than DC 
and DPN subjects. During the TUGT the DPN group needed significantly more time than HC group (an increase of 29\%); no differences were observed between the other groups.

\section{Quality of life}

In the DPN group six of the nine SF36 items and in the DC group seven of the SF 36 items were significantly lower than in the HC group (Table 2). No differences were observed in perceived HR-QoL between both diabetic groups.

\section{Correlations}

Significant correlations were observed between all items of the SF36 and muscle strength, except for health change and role limitations related to emotional problems. The other seven items had significant positive correlations $(p<0.05)$ with dorsal and plantar flexion as well as knee flexion and extension maximal voluntary muscle strength. The correlation coefficients of these associations were between 0.19 and 0.41 .

Similar results were found when the nine SF36 items were correlated with the mobility tests, except for health change and mental health. The other seven items were correlated $(p<0.05)$ with the 6MWT and the PASE questionnaire with correlation coefficients between 0.20 and 0.59 . The same seven items of the SF36 questionnaire had negative correlations with the TUGT (R between -0.29 and -0.46 , $p<0.05)$.

Finally, all muscle strength parameters were correlated with the mobility parameters $(p<0.05)$, with correlation coefficients between 0.22 and 0.59 .

No significant correlations were observed for the $\mathrm{Fl}$ of the ankle and dorsal flexors and knee extensors and flexors and the QoL and mobility parameters.

The level of DPN (CNE score) had no significant influence on the majority of parameters, except that a correlation was observed between the severity of DPN and the TUGT $(R=0.28, p<0.05)$.

\section{Discussion}

The present study clearly demonstrated that DM2 is associated with a marked reduction in lower leg muscle strength, that muscle strength was correlated with mobility and that loss of both lower leg muscle strength and of mobility is associated with a loss of HR-Qol in these elderly patients. We did not observe in this study major differences in muscle strength, mobility (except for the TUGT) and 
QoL between the diabetic patients with and without DPN. One of the innovative aspects of the current study was that we studied the triad leg muscle strength, mobility and quality of life in the same patients.

Although there are numerous studies on abnormal muscle metabolism and its role in the development of insulin resistance, the number of studies on muscle strength and its role in the development of impaired mobility and quality of life in DM2 is limited. Based on the present results we could conclude that DM2 has a major effect on maximal muscle strength with reductions of approximately $30-50 \%$ in both the upper and lower leg. Our findings are in line with previous studies that reported loss of muscle strength in patients with DM2, although the loss of muscle strength was in our study larger than the studies reported earlier $(5,11,14,20-22)$. In the Health ABC Study, elderly adults (mean age 74 years) with DM2 had a mean reduction of leg muscle strength of approximately $3 \%$ although muscle mass in their legs was greater than those without diabetes. Muscle quality (strength corrected for muscle mass) was therefore reduced with approximately $7 \%$ (22). We found a much larger reduction in muscle strength in our patients, that may be (in part) related to differences in the calculation of muscle strength. We corrected muscle strength for body weight, while this was not done in the Health $A B C$ study (22); if we recalculate the data of this latter study the diabetic patients had a reduction in muscle strength of approximately $10 \%$, which is still less than in the present study. Another explanation could be that our control subjects were relative fit and had a higher muscle strength compared to the control subjects in the Health ABC study (22). Several mechanisms, alone or in concert, could be responsible for the loss of muscle strength in DM2. As lack of physical exercise is one of the central mechanisms in the development of DM2, inactivity and disuse probably contribute to the relative poor muscle strength. Moreover, abnormal mitochondrial function, abnormal free fatty acid metabolism and an inadequate rise in microvascular blood supply during exercise $(23,24)$ could further impair muscle function. In the current study we did not observe a relation between loss of nerve function and loss of muscle strength, in contrast to earlier studies $(5,12)$. One of the likely explanations is that the majority of our DPN patients had relative mild DPN. In the studies of Andersen et al. (5) and of Andreassen et al. (12) leg muscle weakness was in particular observed in patients with severe, symptomatic, neuropathy and not in patients with less severe DPN. These data suggest that additional loss of muscle strength is a relatively late phenomenon in the course of DPN and occurs at a severe stage of the disease.

Muscle fatiguability, determined with an isokinetic protocol, was somewhat increased in our diabetic patients, but these differences were clearly less prominent than the decline of maximal voluntary muscle strength, determined with an isometric protocol. Oberbach et al showed that patient with DM2 have increased proportion of muscle fiber type 2 (fast twitch fiber) and decreased proportion of muscle fiber type 1 (slow twitch and responsible for endurance capacity of a muscle) (25). Changes in 
fiber composition could therefore (in part) explain the increased muscle fatiguability in patients with DM2. In contrast, in type 1 diabetic patients Andersen et al (26) observed, a significant higher $\mathrm{Fl}$ of five percent in comparison to healthy volunteers while lower leg muscle strength was reduced, as in our type 2 patients. At this moment we cannot give an explanation for this discrepancy between type 1 and type 2 diabetic patients, but this might be related to underlying insulin resistance and impaired metabolic flexibility in type 2 diabetes (27). We could not find a relation between muscle fatiguability and DPN, as also reported earlier (26). However, research in the field of muscle fatiguability in DM2 patients is scarce and more (human) research is needed to gain a clear insight into this phenomenon.

Muscle strength is one of the important determinants of mobility in diabetic patients. In an earlier population based study we observed that hand grip strength predicted the number of steps taken during the day by patients with DM2 (14). Our current data further extend this observation as reductions in muscle strengths in both the upper and lower leg were associated with the marked loss of mobility in our diabetic patients. As in our earlier study we did not observe a major impact of DPN on the mobility tests we performed, except the TUGT (14). The TUGT was the most challenging mobility test for our subjects and poor performance during this test is probably (in part) related to the loss of propriocepsis in our DPN patients. DPN is associated with several changes in gait characteristics, such as reduced gait velocity, step length and frequency and postural instability, which in part may be related to loss of propriocepsis (28); moreover in patients with DPN the timing of muscle activation is altered during walking as we recently observed (29). In addition, although Van Sloten et al. (14) did not find significant associations between DPN and functional mobility test in a laboratory setting, those DPN patients were significantly less active in daily life with a marked reduction in the number of steps/ day when compared to subjects without DPN. These data of Van Sloten et al were in line with the conclusions of Allet et al. (28); these authors found that diabetic patients, and in particular DPN patients, have deteriorated temporal and spatial gait parameters during walking tests in challenging daily life situations.

These studies suggest that (moderate) DPN does not have a large effect on the capability to be active, but more on mobility behavior and on gait characteristics, in particular in a more challenging environment. Future studies addressing the effect of DPN on mobility should therefore focus more on mobility and functional mobility tasks in daily life to determine the impact of DPN on the actual mobility capability in diabetic patients.

HR-QoL was decreased in our group of DM2 patients compared to healthy persons as shown in several studies (30) and the association between mobility and HR-QoL was observed by other authors $(4,31)$. Diminished muscle strength and mobility can result in infirmities and more dependence in 
daily life with negative influence on HR-QoL. The significant correlations between muscle strength, mobility and HR-QoL parameters showed this association clearly. In addition, there was no clear difference in HR-QoL between our DC and DPN group, in contrast with other studies (7). An explanation can be found in the study Currie et al. (32), these authors concluded that diminished QoL in DPN is associated with the level of pain that is experienced. In the current study most patients had painless DPN and we did not observe differences in pain between the DC and DPN group.

Our study had some limitations. The mean age of the DC group was significantly lower than in the HC group. This could lead to an overestimation of the results of the DC subjects compared to the HC group. To correct for this, age was entered as a covariate in the statistical analysis. The results of the DC group are comparable with the DPN group who had similar age as the HC group. If there would have been an important age effect, we would have expected the DC group to have higher muscle strength, mobility and QoL than the DPN group. This turned out not to be the case. In addition, the DC group included relatively more female participants than both other groups and therefore we used also gender as a covariate in our statistical analysis.

In conclusion, in this study we demonstrated that DM2 patients have decreased maximal muscle strength of the plantar and dorsal flexors of the ankle joint and of the extensors and flexors of the knee joint and that they suffer from impaired mobility. These abnormalities are associated with a loss of health related quality of life. The additional effect of moderate DPN was small in our patients. Physical exercise is one of the cornerstones in the prevention and treatment of diabetes; our data suggest that in the future more emphasis could be placed on interventions to increase leg muscle strength to improve mobility in patients with type 2 diabetes. 


\section{References}

1. Orr R, Tsang T, Lam P, Comino E, Singh MF. Mobility impairment in type 2 diabetes: association with muscle power and effect of Tai Chi intervention. Diabetes Care. 2006 Sep;29(9):2120-2.

2. Volpato S, Blaum C, Resnick H, Ferrucci L, Fried LP, Guralnik JM. Comorbidities and impairments explaining the association between diabetes and lower extremity disability: The Women's Health and Aging Study. Diabetes Care. 2002 Apr;25(4):678-83.

3. Volpato S, Ferrucci L, Blaum C, Ostir G, Cappola A, Fried LP, et al. Progression of lowerextremity disability in older women with diabetes: the Women's Health and Aging Study. Diabetes Care. 2003 Jan;26(1):70-5.

4. Gregg EW, Beckles GL, Williamson DF, Leveille SG, Langlois JA, Engelgau MM, et al. Diabetes and physical disability among older U.S. adults. Diabetes Care. 2000 Sep;23(9):1272-7.

5. Andersen $\mathrm{H}$, Nielsen $\mathrm{S}$, Mogensen $\mathrm{CE}$, Jakobsen J. Muscle strength in type 2 diabetes. Diabetes. 2004 Jun;53(6):1543-8.

6. van Schie $\mathrm{CH}$, Vermigli C, Carrington AL, Boulton A. Muscle weakness and foot deformities in diabetes: relationship to neuropathy and foot ulceration in caucasian diabetic men. Diabetes Care. 2004 Jul;27(7):1668-73.

7. van Schie CH. Neuropathy: mobility and quality of life. Diabetes Metab Res Rev. 2008 MayJun;24 Suppl 1:S45-51.

8. Vinik Al, Strotmeyer ES, Nakave AA, Patel CV. Diabetic neuropathy in older adults. Clin Geriatr Med. 2008 Aug;24(3):407-35, v.

9. Kumar S, Ashe HA, Parnell LN, Fernando DJ, Tsigos C, Young RJ, et al. The prevalence of foot ulceration and its correlates in type 2 diabetic patients: a population-based study. Diabet Med. 1994 Jun;11(5):480-4.

10. Cabezas-Cerrato J. The prevalence of clinical diabetic polyneuropathy in Spain: a study in primary care and hospital clinic groups. Neuropathy Spanish Study Group of the Spanish Diabetes Society (SDS). Diabetologia. 1998 Nov;41(11):1263-9.

11. Andersen H, Poulsen PL, Mogensen CE, Jakobsen J. Isokinetic muscle strength in long-term IDDM patients in relation to diabetic complications. Diabetes. 1996 Apr;45(4):440-5.

12. Andreassen CS, Jakobsen J, Andersen H. Muscle weakness: a progressive late complication in diabetic distal symmetric polyneuropathy. Diabetes. 2006 Mar;55(3):806-12.

13. Andreassen CS, Jakobsen J, Ringgaard S, Ejskjaer N, Andersen H. Accelerated atrophy of lower leg and foot muscles--a follow-up study of long-term diabetic polyneuropathy using magnetic resonance imaging (MRI). Diabetologia. 2009 Jun;52(6):1182-91.

14. van Sloten TT, Savelberg HH, Duimel-Peeters IG, Meijer K, Henry RM, Stehouwer CD, et al. Peripheral neuropathy, decreased muscle strength and obesity are strongly associated with walking in persons with type 2 diabetes without manifest mobility limitations. Diabetes Res Clin Pract. 2010 Oct 19.

15. Valk GD, de Sonnaville JJ, van Houtum WH, Heine RJ, van Eijk JT, Bouter LM, et al. The assessment of diabetic polyneuropathy in daily clinical practice: reproducibility and validity of Semmes Weinstein monofilaments examination and clinical neurological examination. Muscle Nerve. 1997 Jan;20(1):116-8.

16. Ijzerman TH, Schaper NC, Melai T, Blijham P, Meijer K, Willems PJ, et al. Motor nerve decline does not underlie muscle weakness in type 2 Diabetic neuropathy. Muscle Nerve. 2011 Aug;44(2):241-5.

17. Gosker HR, Lencer NH, Franssen FM, van der Vusse GJ, Wouters EF, Schols AM. Striking similarities in systemic factors contributing to decreased exercise capacity in patients with severe chronic heart failure or COPD. Chest. 2003 May;123(5):1416-24.

18. Moreau N, Li L, Damiano DL. A feasible and reliable muscle fatigue assessment protocol for individuals with cerebral palsy. Pediatr Phys Ther. 2008 Spring;20(1):59-65. 
19. Brazier JE, Harper R, Jones NM, O'Cathain A, Thomas KJ, Usherwood T, et al. Validating the SF-36 health survey questionnaire: new outcome measure for primary care. BMJ. 1992 Jul 18;305(6846):160-4.

20. Sayer AA, Dennison EM, Syddall HE, Gilbody HJ, Phillips DI, Cooper C. Type 2 diabetes, muscle strength, and impaired physical function: the tip of the iceberg? Diabetes Care. 2005 Oct;28(10):2541-2.

21. Park SW, Goodpaster BH, Strotmeyer ES, Kuller LH, Broudeau R, Kammerer C, et al. Accelerated loss of skeletal muscle strength in older adults with type 2 diabetes: the health, aging, and body composition study. Diabetes Care. 2007 Jun;30(6):1507-12.

22. Park SW, Goodpaster BH, Strotmeyer ES, de Rekeneire N, Harris TB, Schwartz AV, et al. Decreased muscle strength and quality in older adults with type 2 diabetes: the health, aging, and body composition study. Diabetes. 2006 Jun;55(6):1813-8.

23. Schrauwen P, Schrauwen-Hinderling V, Hoeks J, Hesselink MK. Mitochondrial dysfunction and lipotoxicity. Biochim Biophys Acta. 2010 Mar;1801(3):266-71.

24. Womack L, Peters D, Barrett EJ, Kaul S, Price W, Lindner JR. Abnormal skeletal muscle capillary recruitment during exercise in patients with type 2 diabetes mellitus and microvascular complications. J Am Coll Cardiol. 2009 Jun 9;53(23):2175-83.

25. Oberbach A, Bossenz Y, Lehmann S, Niebauer J, Adams V, Paschke R, et al. Altered fiber distribution and fiber-specific glycolytic and oxidative enzyme activity in skeletal muscle of patients with type 2 diabetes. Diabetes Care. 2006 Apr;29(4):895-900.

26. Andersen H. Muscular endurance in long-term IDDM patients. Diabetes Care. 1998 Apr;21(4):604-9.

27. Corpeleijn E, Saris WH, Blaak EE. Metabolic flexibility in the development of insulin resistance and type 2 diabetes: effects of lifestyle. Obes Rev. 2009 Mar;10(2):178-93.

28. Allet L, Armand S, de Bie RA, Pataky Z, Aminian K, Herrmann FR, et al. Gait alterations of diabetic patients while walking on different surfaces. Gait Posture. 2009 Apr;29(3):488-93.

29. Savelberg HH, Ilgin D, Angin S, Willems PJ, Schaper NC, Meijer K. Prolonged activity of knee extensors and dorsal flexors is associated with adaptations in gait in diabetes and diabetic polyneuropathy. Clin Biomech (Bristol, Avon). 2010 Jun;25(5):468-75.

30. Norris SL, McNally TK, Zhang X, Burda B, Chan B, Chowdhury FM, et al. Published norms underestimate the health-related quality of life among persons with type 2 diabetes. J Clin Epidemiol. 2011 Apr;64(4):358-65.

31. Benbow SJ, Wallymahmed ME, MacFarlane IA. Diabetic peripheral neuropathy and quality of life. Qjm. 1998 Nov;91(11):733-7.

32. Currie CJ, Poole CD, Woehl A, Morgan CL, Cawley S, Rousculp MD, et al. The health-related utility and health-related quality of life of hospital-treated subjects with type 1 or type 2 diabetes with particular reference to differing severity of peripheral neuropathy. Diabetologia. 2006 Oct;49(10):2272-80. 


\section{Chapter 4}

Resistance training improves plantar flexor strength and walking speed in people with diabetic polyneuropathy

T. Herman IJzerman, Nicolaas C. Schaper, Tom Melai, Valeria Lima Passos, Kenneth Meijer, Paul J.B. Willems, Hans H.C.M. Savelberg

Submitted 


\begin{abstract}
The purpose of the current study was to evaluate the acute and long term effects of a moderately intensive intervention on muscle strength, mobility and health related quality of life in patients with diabetic polyneuropathy.

Patients with diabetic polyneuropathy were randomized to an intervention group (INT, n=51) and a control group ( $\mathrm{CON} n=47$ ). The INT group followed an intervention of 24 weeks, with three practices a week based on lower extremity strength and mobility training. All subjects were measured four times, at baseline and after 12, 24 and 52 weeks. Both groups performed isometric and isokinetic knee and ankle strength tests. Mobility was determined by a timed 'up and go' test, a six minute walk test (6MWT) and the physical activity scale for the elderly questionnaire. Health related quality of life was determined by the SF36 questionnaire.

The INT group showed significant improvement on plantar muscle strength and functional mobility (6MWT) after 52 weeks (44\% and 6\% respectively) when compared to baseline data. No changes over time were found in the CON group. The other strength and mobility parameters and the self reported Health related quality of life did not differ significantly in both groups. During the one year follow-up dropout percentages were high in both groups. (INT 53\%, CON 36\%).

An intervention aimed at improving muscle strength and functional mobility can have acute and long term beneficial effects for patients with diabetic polyneuropathy. However, the high dropout rate suggests that DPN patients are physical vulnerable.
\end{abstract}




\section{Introduction}

Diabetic polyneuropathy (DPN) is a common complication in patients with diabetes mellitus type 2 (DM2). DPN develops in approximately $20-40 \%$ of all diabetic patients $(1,2)$ and has been associated with decreased sensation, muscle strength, mobility and health related quality of life (HR-QoL) (3-8). In one cross-sectional study muscle strength around the ankle joint was reduced by $41 \%$ in patients with DPN compared to diabetic patients without DPN; MRI data obtained in that study suggested atrophy as an underlying cause (9). This muscle weakness and atrophy are probably the result of an increased rate of muscle strength loss in DPN; whereas control subjects lost about $0.8 \%$ of their muscle strength of ankle plantar and dorsal flexors each year, muscle strength decreased by $3.2 \%$ per year in patients with symptomatic neuropathy and this loss was related to the severity of neuropathy (4). Muscle weakness in diabetic neuropathy is not limited to distal lower limb muscles, but extends at a lower degree- to knee extensors and flexors in the upper leg (3).

Patients with DM2 who have diminished muscle strength are likely to have more difficulties being active in daily life and a close relation was observed between diminished muscle strength and impaired mobility and HR-QoL (10). In a community based study, DM2 patients with DPN took, after correction for other factors effecting mobility, almost $30 \%$ steps per day less compared to patients without neuropathy (5). Therefore, patients with DPN are at risk of entering a vicious circle with decreased muscle strength resulting in physical inactivity and inactivity causing a further decrease in muscle strength, resulting in a progressive loss of mobility, with both social and medical consequences

Currently there is no causal treatment for diabetic neuropathy and new strategies are needed to improve muscle strength, mobility and the poor HR-QoL in patients with DPN. As in DPN the muscles of the (lower) leg are affected in particular, a muscle strength training program should be focussed on improving lower extremity function and should be directly related to daily activities to improve mobility most advantageously (11). Promising results have been achieved with muscle strength training programs in patients with type 2 diabetes mellitus after a training period up to 6 months (1214). However, little is known about the trainability of patients with DPN and the effect of increasing muscle strength on mobility and HR-QoL. Allet et al. (15) showed that specific resistance training of the lower extremities can lead to increased muscle strength and higher gait speed in DPN patients. In addition, it has been shown in a small feasibility study that exercise could increase muscle strength in patients with DPN (16). Both aforementioned studies suggest that the loss of muscle strength is at least partially reversible after a specific training program. However, in these two studies the effect of increased muscle strength on mobility and HR-QoL has not been analyzed. Moreover, in addition to muscle weakness also other consequences of neuropathy could affect mobility of DPN patients such 
as decreased sensation, impaired muscle coordination, and loss of sensory-motor feedback resulting in impaired postural stability and altered gait pattern which could increase the risk of training related adverse events (7).

The aim of the present study was to evaluate in a randomised controlled clinical trial the effects of resistance training on lower limb muscle strength, on mobility and on HR-QoL in patients with DPN. Moreover, we evaluated whether a change in activity behaviour is retained after the training program was stopped.

\section{Methods}

\section{Study design}

This study was a multicenter, open, randomized controlled trial with a parallel group design that examined the effects of a specific strength and mobility intervention. Each participant performed all training sessions and measurements at the same institute, either at the Department of Human Movement Sciences of Maastricht University Medical Centre or at Fontys University of Applied Sciences in Eindhoven. The intervention group (INT) participated in a 24 week training program. As denervation in DPN develops from distal to proximal, the first 12 weeks were aimed at improving strength of the lower legs and the second 12 weeks were aimed at improving strength of the whole leg. All outcome measures were assessed before the intervention $(T=0)$, after 12 weeks $(T=12)$, after 24 weeks $(T=24)$ and half a year after the intervention $(T=52)$. The control group (CON) only performed the assessments at the given time points and were asked to continue their normal activities during the year of the study. The study was initially intended to be blinded for the outcome assessors but this could not be maintained as many subjects were not able to conceal their allocation during the measurements. The study was approved by the ethical committee of Maastricht University Medical Centre; written informed consent was obtained from all participants.

\section{Subjects}

Patients with DPN were recruited in one university and four district hospitals in the south of the Netherlands. To be included, subjects had to be diagnosed with type 2 diabetes, to be above 50 years of age, to be diagnosed with DPN (see below) and to be able to walk 6 minutes without walking aids. Patients were excluded if they had severe cardiac disease, renal insufficiency (creatinine> 180 $\mu \mathrm{mol} / \mathrm{I})$, intermittent claudication, foot ulcers in the last six months prior to the study, or nerve 
damage not due to DPN. DPN was diagnosed and classified based on a standardised clinical neurological examination (CNE). This validated clinical scoring system assesses the anatomic level below which light touch sensation is impaired, the sensory modalities, as well as the muscle strength of the ankle joint and feet and the functioning of the ankle joint reflexes. Using these modalities, the CNE score was calculated, the higher the score the more severe is the nerve damage; a CNE score $\geq 5$ indicated the presence of peripheral neuropathy and a score of $\geq 15$ was considered as severe DPN (17).

\section{Randomization and intervention}

In each institute the participants were randomized using the envelope method to the intervention or the control group receiving no training (figure 1). Both groups were free to perform any additional physical activity outside the trial. The subjects assigned to the intervention were divided over 5 subgroups to receive weekly plenary training for 24 weeks, guided by a physical therapist under supervision of a member of the research team. The aim was to improve muscle strength of the lower limb in functional terms, like rising from a chair and subsequently to integrate these activities in daily life. During the first 12 weeks the focus was on the lower leg with training of the dorsal and plantar flexors and lower leg coordination; during the next 12 weeks the muscles of the entire lower extremity were trained. Each session lasted $1 \frac{1}{2}$ hour and consisted of a warming-up followed by lower extremity muscle training using elastic bands, weight vests and ankle weights, gradually increasing from low to moderate intensity at 40 to $60 \%$ of one repeated maximum (12-16 repetitions). An example of such an exercise is resisted dorsiflexion and plantar flexion: the participant was sitting on a chair with an elastic band with predetermined resistance secured around the balls of the feet. Both heels were on the floor with the ankle in approximately $90^{\circ}$ and one foot was moved repeatedly toward plantar flexion and dorsiflexion, while no exercises were performed with the contra-lateral foot. As DPN patients frequently have multiple co-morbidities, with elevated risk of injuries and cardiac problems, a moderate training intensity was chosen. The third part of a training session included functional gait tasks in a challenging gait track with obstacles resembling activities of daily life and each session was concluded with various interactive games. In addition to these plenary sessions, subjects were provided with an exercise manual and were asked to carry on the lower extremity muscles exercises two times a week at home. A detailed description of the training is provided in the Addendum.

\section{Endpoints and measurements}


The primary outcome measure was mobility. Muscle strength and HR-QoL were set as secondary outcome measures. Measurements were taken at $\mathrm{T}=0, \mathrm{~T}=12, \mathrm{~T}=24$ and $\mathrm{T}=52$ for both groups.

\section{Muscle function}

Two validated dynamometers, a Biodex System 3 (Biodex Medical Systems, New York) and a Cybex II (CMSI, Stoughton, MA) were used to determine isometric and isokinetic muscle strength and the fatigue index $(\mathrm{Fl})$ of dorsal and plantar flexors of the ankle joint and of knee joint extensors and flexors. To determine relative fatigue the fatigue index (FI) subjects performed 20 repetitions. The FI was calculated as the ratio of the mean work of the 16th till 20th repetition over the mean work of the highest, five consecutive repetitions within the first eight repetitions. A Fl approaching $0 \%$ indicates that work decline during the test is high (18). According to an earlier study, results were similar for both dynamometers (19). Repeated measurements on individual subjects were performed at the same dynamometer. The protocol for isometric measurements has been described in an earlier study of our research group (10).

\section{Mobility}

Subjects underwent three tests to assess physical mobility.

1. The six minute walk test (6MWT) was performed to assess the level of walking capacity; it measures the distance a subject can quickly walk within six minutes without running (20). At one institute a $200 \mathrm{~m}$ square shaped track was used, at the other institute participants walked up and down a 50 m corridor.

2. The timed up and go test (TUGT) was performed to determine functional mobility. The subjects were asked to stand up from a chair, walk three metres, turn $180^{\circ}$, walk back and sit down again (21). The test was performed at comfortable speed. The average time of three attempts was calculated.

3. The physical scale of the elderly (PASE) questionnaire was used to determine the self perceived daily activity pattern of each subject (22).

Health related quality of life and training experiences and blood samples

HR-QoL was determined with the SF36 questionnaire, which contains 36 items and measures self perceived health on nine multi item dimensions, based on functional status, well being and overall evaluation of health (23). A higher score on an item represents a higher level of experienced HR-QoL. 
After the intervention, subjects of the INT group were asked to fill in a short questionnaire on their appreciation of the training program using a five point scale. Overnight fasting blood samples were drawn on $\mathrm{T}=0, \mathrm{~T}=24$ and $\mathrm{T}=52$ for measurement of glucose, glycated hemoglobin (HbA1c) and creatinine.

Dropout

As reported in the result section, there was a high dropout rate in both the intervention and control arms, with increasing health problems being the most common reason for dropout. Because of these injuries the subjects could not perform the muscle strength and mobility measurements and subjects who droppedout because of motivational problems were not willing to perform the measurements (fig 2). Therefore, only the participants who completed the 12 months trial were included in the analyses.

\section{Statistical analysis}

Data are presented as mean \pm standard error. Independent t-test for baseline values were used to assess whether there were differences in patient characteristics between the subjects who dropped out and the subjects who completed the trial.

To evaluate average changes of the outcome measures over time, adjusting for possible confounders and time-dependent covariates, a complete cases analysis was conducted (i.e. only for those participants with full compliance throughout the 12 months trial). For this purpose, mixed linear regression models were fitted. Age, sex, group, time and centre were the fixed effects; subjects were the random effect (random intercept only). A significant interaction group*time was expected, suggesting a possible improvement of outcome parameters over time for the intervention group. The top down procedure was chosen for variable selection. Model parameters were estimated via the restricted maximum likelihood method. Based on the means estimated by the final models, Bonferroni post hoc analysis was applied for multiple pair wise comparisons between groups and time points of outcome parameters. A p-value of $<0.05$ was considered as significant. All analyses were performed using SPSS 15.0 software.

\section{Results}

Baseline characteristics 
A total of 98 DPN patients were recruited for this study. After randomisation, 51 patients ( 43 male, 8 female) were included in the INT group and 47 patients ( 37 male, 10 female) in the CON group. There were no significant differences between both groups (table 1). In general older, obese subjects with type 2 diabetes were included with moderate regulation of these blood glucose levels and, based on the CNE score, with moderate DPN.

Table 1: Subject characteristics after randomisation

\begin{tabular}{l|l|l} 
& INT & CON \\
\hline Age $(\mathrm{yr})$ & $67 \pm 1$ & $66 \pm 1$ \\
\hline Height $(\mathrm{m})$ & $1.75 \pm 0.01$ & $1.73 \pm 1$ \\
\hline Weight $(\mathrm{kg})$ & $90.5 \pm 2.3$ & $92.1 \pm 2.4$ \\
\hline CNE score T=0 & $13 \pm 4$ & $13 \pm 1$ \\
\hline Fasting blood glucose $(\mathrm{mmol} / \mathrm{L})$ & $8.3 \pm 0.3$ & $8.4 \pm 0.3$ \\
\hline HbA $_{1 \mathrm{c}}(\%)$ & $7.7 \pm 0.1$ & $7.4 \pm 0.2$ \\
\hline Creatinine ( $\mu \mathrm{mol} / \mathrm{L})$ & $103 \pm 5$ & $98 \pm 3$ \\
\hline Values a &
\end{tabular}

Values are presented as means \pm standard error of the mean.

\section{Program adherence, follow up and adverse advents}

In both groups, dropout rate was high, $53 \%$ in the INT group (male: 21 , female: 6 ) and $36 \%$ in the CON group (male: 14, female: 3). Dropout was clearly higher in the INT group. Seven INT patients refrained because of intervention related injuries (two subjects with ulceration and five with knee complaints), seven patients because of injuries that were not related to the intervention (e.g. cardiac complaints, cancer and cataract surgery), six stopped because of lack of motivation and seven patients had various other reasons to quit. Eight CON subjects refrained because of physical impairments (e.g. cardiac and pulmonary complaints), three had motivational problems and six patients had other reasons to quit. Relatively more women than men dropped out during the study (50 and $44 \%$ respectively, $p<0.05$ ). Patients who dropped out had higher CNE scores in comparison to patients who did not: 14 and $11(p<0.05)$, no further differences were observed in the baseline parameters (e.g. age, weight, mobility and muscle strength) between INT and CON patients.

Twenty-two males and two females of the INT group, and 23 males and seven females of the CON group completed the study. Weight, fasting blood glucose levels, HbA1c and creatinine did not differ significantly between groups nor changed significantly over time. Nerve function deteriorated in both groups over 52 weeks (CNE score: $10 \pm 1$ at T=0 in both groups and $12 \pm 1$ at T=52 in both groups; $p<$ 0.05). 


\section{Muscle function}

At baseline no significant differences between both groups were measured for all muscle strength parameters. Compared to CON participants, INT participants increased maximal plantar ankle flexion strength by $44 \%$ from $0.55 \pm 0.09$ to $0.79 \pm 0.09 \mathrm{Nm} / \mathrm{kg}$ after a year (Interaction time*group $\mathrm{p}=0.024$; fig. 1). At baseline maximal dorsal flexion strength, maximal knee extension and flexion strength were all three identical in both groups $(0.33 \pm 0.01,1.31 \pm 0.06$ and $0.66 \pm 0.05 \mathrm{Nm} / \mathrm{kg})$, and all three parameters did not change significantly during 52 weeks. Also the $\mathrm{Fl}$ of the plantar flexors, dorsal flexors, knee extensors and knee flexors were not significantly different at baseline and did not change during 52 weeks: $62 \pm 3,46 \pm 2,66 \pm 2,71 \pm 2 \%$, respectively.

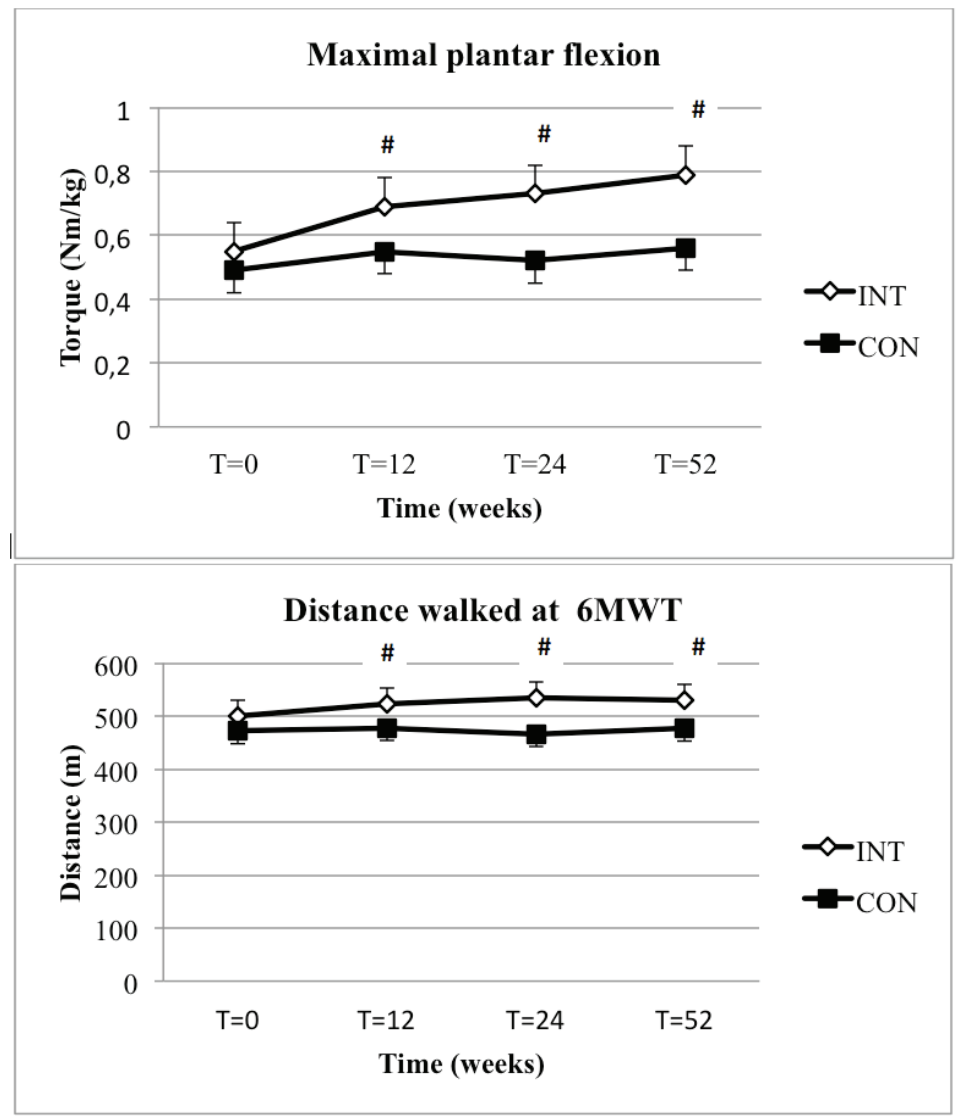

Fig. 1 Maximal plantar flexion strength and distance walked at the 6MWT over 52 weeks.

Values represent predicted means and $p$ values related to the model estimate for the age, gender, group, time and group*time effect.

\# Significant different compared to $\mathrm{T}=0(\mathrm{p}<0.05)$. 
Mobility

There was no significant group difference between the INT and CON group at baseline. Compared to the CON group the distance walked at the 6MWT significantly improved $6 \%$ due to the intervention (interaction: group*time $p=0.002$ ) from $500 \pm 30$ to $530 \pm 30 \mathrm{~m}$ (fig 1). No institute effect was determined for the 6MWT. No significant time, group or intervention effects were found for the score at the PASE questionnaire. Both groups had identical scores of $155 \pm 14$. There was a significant time effect for the time walked at the TUGT. In comparison to baseline both the INT and CON groups walked faster after 52 weeks, with the CON group walking slower at both time points: 9.0 vs $9.7 \mathrm{~s}$ and 7.7 vs 8.4 s, respectively $(p<0.05)$.

Health related quality of life

The INT group had, compared to the CON group, about 15\% higher estimated HR-QoL scores on social functioning, pain and health change: $89 \pm 5$ vs. $77 \pm 4$ ( $p=0,041), 81 \pm 5$ vs. $71 \pm 4(p=0,032)$ and $48 \pm 4$ vs. $41 \pm 3(p=0,007)$, respectively. No differences were observed in the other SF-36 HR-QoL domains (data not shown). No intervention or time effect was found in any HR-QoL item.

\section{Experiences of the intervention}

The subjects reported that they were positive about the intervention. Participants experienced exercising with fellow patients as pleasant and they would recommend this intervention to other patients. In addition, participants reported that they felt physically fitter after the intervention and they looked forward to go to the plenary sessions. 


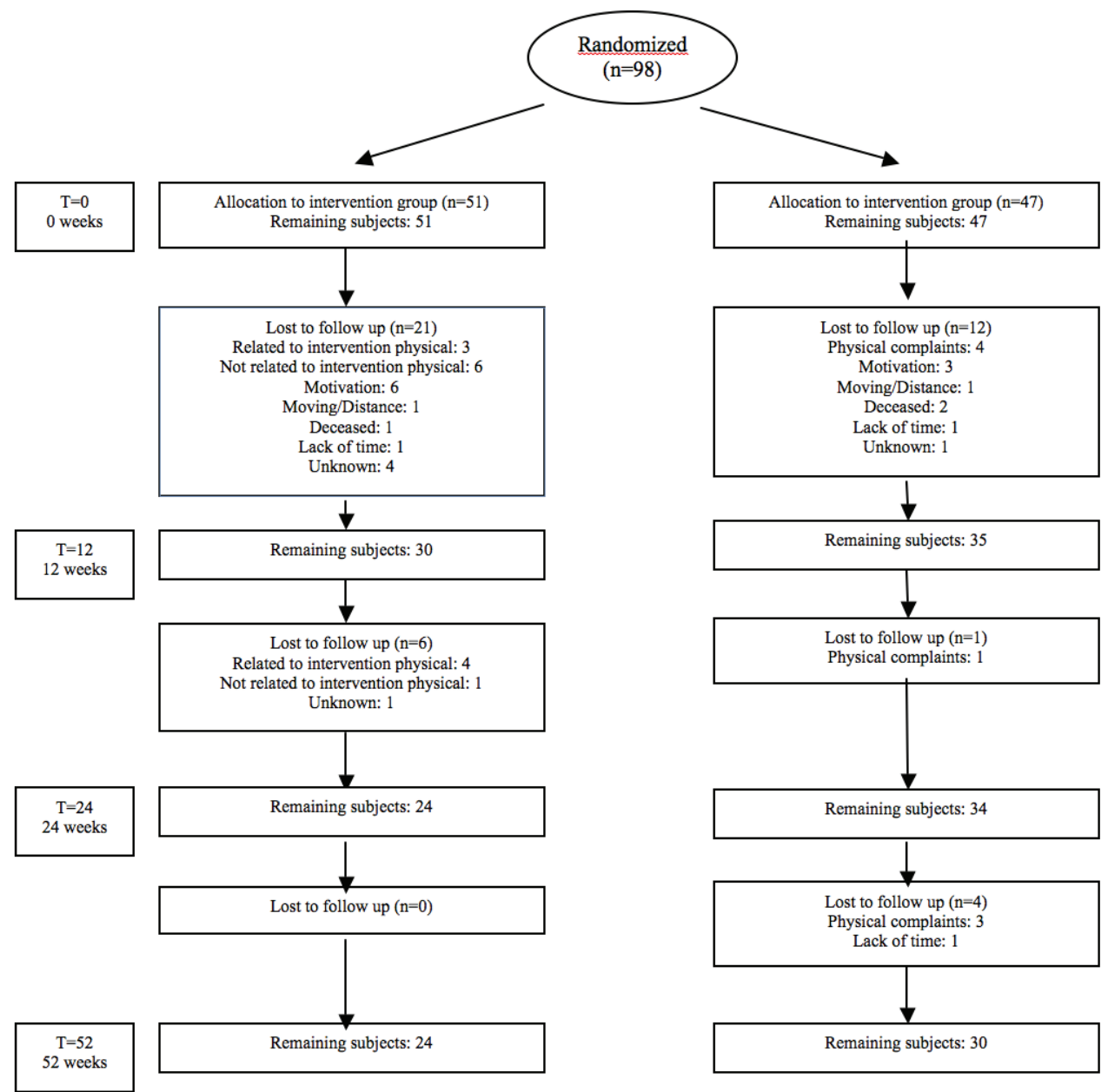

Fig. 2 Subject disposition

\section{Discussion}

Progressive loss of lower leg muscle strength is one of the consequences of DPN and the results of this study suggest that a 24 week muscle strength and mobility program can improve plantar flexion strength and walking speed. Moreover, these effects were still present half a year after the intervention was stopped. However, these improvements did not result in an increased quality of life. Dropout rate was high in the current study, probably caused by the vulnerability of the patients and patients with less severe nerve damage had a better chance to complete successfully the intervention program. 
Muscle strength of the ankle plantar flexors increased during the first 12 weeks of the training program, in line with earlier studies $(15,16,24)$, but no further increase was observed between week 12 and 24 . The lack of an additional increase during the second 12 weeks may be caused by a ceiling effect due to low intensity training. Furthermore, the first 12 weeks were aimed at improving muscle strength in the lower legs, while the second 12 weeks were aimed at improving muscle strength of the whole leg. Importantly, after the $1 / 2$ year follow-up the plantar flexor muscle strength remained a $44 \%$ higher in the intervention group, indicating a more long-term beneficial effect. Our patients had moderate DPN based on the CNE score, as DPN affects the lower leg earlier than the upper leg it is likely that the largest effect could be obtained in the lower leg muscles. Alternatively, the exercises of the upper leg may have been of too low intensity to improve isolated upper leg muscle strength measured with a dynamometer. We observed a marked increase in ankle joint plantar flexion strength but the training did not seem to affect the dorsal flexors. The training sessions consisted of general walking exercises and exercises that were aimed to improve specific muscle groups. In order to improve plantar flexion strength subjects were instructed to perform 'raising heels' exercises and dorsal flexion against resistance. To improve dorsal flexor strength subjects were instructed to perform walking on heels exercises and to pull up their foot with an elastic band. Several participants reported that these latter exercises were more difficult to execute and could not always be performed, so the training intensity of the dorsal flexors may have been too low. To improve dorsal flexor function, exercises which are easier to execute for DPN patients may be necessary. An example of such an exercise is walking upwards a slope. With this exercise both plantar flexors and dorsal flexors will be trained.

Lower leg muscle training resulted in this RCT in a modest increase of the distance walked at the 6MWT. In a previous study we observed that healthy elderly walk around $600 \mathrm{~m}$ (10). In the current study the DPN patients walked approximately $500 \mathrm{~m}$ before the intervention and after 12 weeks walking distance increased with $30 \mathrm{~m}$. Comparable results were found in a study of Mueller et al. where a difference of $29 \mathrm{~m}$ was measured (25). A difference of more than $20 \mathrm{~m}$ is considered clinical relevant (26). No further increase was noted after 12 weeks and the increase walking distance was maintained during the $1 / 2$ year follow-up. The increase of the plantar flexion strength could have improved the push off phase during walking, resulting in increased walking speed during the 6minutes walking test. Alternatively, the increase in walking speed could have been the consequence of improved (perceived) balance. Although balance was not measured, participants reported during the training sessions that they felt less unsteady and were less afraid to trip and fall when walking on the street. This is in line with a recently published literature review (24) in which the authors concluded that muscle strength training and balance exercises could lead to decreased risk of falling in patients with DPN. In addition, in the questionnaire on the training subjects reported that they felt 
physically fitter. Unsteadiness with reduced mobility is a major negative consequence of DPN; we suggest future interventions to evaluate the combination of exercises to improve muscle strength and to improve balance and coordination. For example exercises like performing knee bends or heel raises while standing on one leg.

No differences were observed in HR-QoL measured with the generic SF36 questionnaire. However, in the questionnaire specifically developed for this RCT to evaluate the experiences of the participants, but that was not validated, participants reported more positive results and in particular subjects reported an increased physical fitness. A disease specific instrument related to mobility problems in DPN should preferably be included in future studies, but to the best of our knowledge no such instrument is currently available. An additional improvement could be the use of more objective measures of daily physical activities, such as tri-axial accelerometers, which can nowadays measure different kinds of activity levels 24 hours/day.

The present study had a relatively high dropout: $53 \%$ of the INT participants did not complete our one year trial, in part because of intervention related injuries. However, dropout rate was also high in the CON group, and was probably a consequence of the relative poor general health status of these individuals. Indeed the higher the DPN score, the higher the likelihood for dropout was, suggesting that muscle strength exercises may particularly be useful for patients with mild to moderate DPN. In a study on the effect of exercise on gait in DPN dropout rates similar to our study were observed in the control group after 12 weeks: $22 \%$ vs $28 \%$ in our study (15). Strikingly, in this latter study a lower dropout rate was observed after 6 months in the intervention group that trained twice a week for twelve weeks under supervision of a physiotherapist: $14 \%$. Currently, we cannot explain these differences, but one of the reasons could be that our patients suffer more from co-morbidities. In addition, poor trainability seems to be a more general characteristic of DM2 patients; in one intervention study, a brisk walking and a medical fitness program, both three times a week, resulted in dropout rates of $76 \%$ and $56 \%$ after 12 months, respectively. Given the relative poor trainability of DNP patients specific measures should be taken in future studies to prevent injuries, such as a more personalised training program that takes individual impairments into account (27).

A major limitation of the present study was that only analyzed the subjects who completed the 12 month trial. With this per protocol analysis there is a clear risk for selection bias; therefore the results should be interpreted with caution. But, our data do suggest that patients with moderate DPN and who are physically able to participate in a long term exercise program may benefit from exercise training. As most dropouts occurred in the first 6 weeks of the intervention (77\%), an early evaluation of trainability should be included in future trainings. Furthermore, the intervention was given by several physiotherapists, to ensure that they interpreted the training instructions equally, they were provided with a manual and they all received individual instructions from the researcher. 
In conclusion, a 24 week intervention as described in the present study can improve plantar muscle strength at the ankle joint and walking speed in subjects who are able to complete the training and this effect is long lasting. In addition, the subjects who followed the intervention highly appreciated the training and they would recommend it to fellow patients. Therefore, it is recommended to prescribe a personal exercise program for patients with DPN based on the trainability and personal goals of the patient because the trainability of these patients is poor. Furthermore, patients seem to prefer training in small groups with fellow patients, under supervision of a physiotherapist. 


\section{References}

1. Kumar S, Ashe HA, Parnell LN, Fernando DJ, Tsigos C, Young RJ, et al. The prevalence of foot ulceration and its correlates in type 2 diabetic patients: a population-based study. Diabet Med. 1994 Jun;11(5):480-4.

2. Cabezas-Cerrato J. The prevalence of clinical diabetic polyneuropathy in Spain: a study in primary care and hospital clinic groups. Neuropathy Spanish Study Group of the Spanish Diabetes Society (SDS). Diabetologia. 1998 Nov;41(11):1263-9.

3. Andersen $\mathrm{H}$, Nielsen $\mathrm{S}$, Mogensen $\mathrm{CE}$, Jakobsen J. Muscle strength in type 2 diabetes. Diabetes. 2004 Jun;53(6):1543-8.

4. Andreassen CS, Jakobsen J, Andersen H. Muscle weakness: a progressive late complication in diabetic distal symmetric polyneuropathy. Diabetes. 2006 Mar;55(3):806-12.

5. van Sloten TT, Savelberg HH, Duimel-Peeters IG, Meijer K, Henry RM, Stehouwer CD, et al. Peripheral neuropathy, decreased muscle strength and obesity are strongly associated with walking in persons with type 2 diabetes without manifest mobility limitations. Diabetes Res Clin Pract. 2010 Oct 19.

6. Clark DJ, Patten C, Reid KF, Carabello RJ, Phillips EM, Fielding RA. Impaired voluntary neuromuscular activation limits muscle power in mobility-limited older adults. J Gerontol A Biol Sci Med Sci. May;65(5):495-502.

7. van Schie CH. Neuropathy: mobility and quality of life. Diabetes Metab Res Rev. 2008 MayJun;24 Suppl 1:S45-51.

8. Benbow SJ, Wallymahmed ME, MacFarlane IA. Diabetic peripheral neuropathy and quality of life. Qjm. 1998 Nov;91(11):733-7.

9. Andersen H, Gadeberg PC, Brock B, Jakobsen J. Muscular atrophy in diabetic neuropathy: a stereological magnetic resonance imaging study. Diabetologia. 1997 Sep;40(9):1062-9.

10. IJzerman TH, Schaper NC, Melai T, Meijer K, Willems PJ, Savelberg HH. Lower extremity muscle strength is reduced in people with type 2 diabetes, with and without polyneuropathy, and is associated with impaired mobility and reduced quality of life. Diabetes Res Clin Pract. 2012 Mar;95(3):345-51.

11. Yeom HA, Keller C, Fleury J. Interventions for promoting mobility in community-dwelling older adults. J Am Acad Nurse Pract. 2009 Feb;21(2):95-100.

12. Cauza E, Hanusch-Enserer U, Strasser B, Ludvik B, Metz-Schimmerl S, Pacini G, et al. The relative benefits of endurance and strength training on the metabolic factors and muscle function of people with type 2 diabetes mellitus. Arch Phys Med Rehabil. 2005 Aug;86(8):1527-33.

13. Larose J, Sigal RJ, Boule NG, Wells GA, Prud'homme D, Fortier MS, et al. Effect of exercise training on physical fitness in type II diabetes mellitus. Med Sci Sports Exerc. 2010 Aug;42(8):1439-47.

14. Colberg SR, Sigal RJ, Fernhall B, Regensteiner JG, Blissmer BJ, Rubin RR, et al. Exercise and type 2 diabetes: the American College of Sports Medicine and the American Diabetes Association: joint position statement. Diabetes Care. 2010 Dec;33(12):e147-67.

15. Allet L, Armand S, de Bie RA, Golay A, Monnin D, Aminian K, et al. The gait and balance of patients with diabetes can be improved: a randomised controlled trial. Diabetologia. 2010 Mar;53(3):458-66.

16. Otterman NM, van Schie $\mathrm{CH}$, van der Schaaf $\mathrm{M}$, van Bon $\mathrm{AC}$, Busch-Westbroek TE, Nollet $\mathrm{F}$. An exercise programme for patients with diabetic complications: a study on feasibility and preliminary effectiveness. Diabet Med. 2011 Feb;28(2):212-7.

17. Valk GD, de Sonnaville JJ, van Houtum WH, Heine RJ, van Eijk JT, Bouter LM, et al. The assessment of diabetic polyneuropathy in daily clinical practice: reproducibility and validity of Semmes Weinstein monofilaments examination and clinical neurological examination. Muscle Nerve. 1997 Jan;20(1):116-8.

18. Moreau N, Li L, Damiano DL. A feasible and reliable muscle fatigue assessment protocol for individuals with cerebral palsy. Pediatr Phys Ther. 2008 Spring;20(1):59-65. 
19. Gosker HR, Lencer NH, Franssen FM, van der Vusse GJ, Wouters EF, Schols AM. Striking similarities in systemic factors contributing to decreased exercise capacity in patients with severe chronic heart failure or COPD. Chest. 2003 May;123(5):1416-24.

20. Lipkin DP, Scriven AJ, Crake T, Poole-Wilson PA. Six minute walking test for assessing exercise capacity in chronic heart failure. Br Med J (Clin Res Ed). 1986 Mar 8;292(6521):653-5.

21. Podsiadlo D, Richardson S. The timed "Up \& Go": a test of basic functional mobility for frail elderly persons. J Am Geriatr Soc. 1991 Feb;39(2):142-8.

22. Washburn RA, Smith KW, Jette AM, Janney CA. The Physical Activity Scale for the Elderly (PASE): development and evaluation. J Clin Epidemiol. 1993 Feb;46(2):153-62.

23. Brazier JE, Harper R, Jones NM, O'Cathain A, Thomas KJ, Usherwood T, et al. Validating the SF-36 health survey questionnaire: new outcome measure for primary care. BMJ. 1992 Jul 18;305(6846):160-4.

24. Tofthagen C, Visovsky C, Berry DL. Strength and balance training for adults with peripheral neuropathy and high risk of fall: current evidence and implications for future research. Oncol Nurs Forum. 2012 Sep;39(5):E416-24.

25. Mueller MJ, Tuttle L, Lemaster JW, Strube MJ, McGill JB, Hastings MK, et al. Weight-Bearing Versus Nonweight-Bearing Exercise for Persons With Diabetes and Peripheral Neuropathy: A Randomized Controlled Trial. Arch Phys Med Rehabil. 2012 Dec 28.

26. Perera S, Mody SH, Woodman RC, Studenski SA. Meaningful change and responsiveness in common physical performance measures in older adults. J Am Geriatr Soc. 2006 May;54(5):743-9.

27. Li L, Hondzinski JM. Select exercise modalities may reverse movement dysfunction because of peripheral neuropathy. Exerc Sport Sci Rev. 2012 Jul;40(3):133-7. 


\section{Chapter 5}

Training program of the study

Resistance training improves plantar flexor strength and walking speed in people with diabetic polyneuropathy 
The training period lasted 24 weeks, with 3 training sessions per week. Once a week there was a plenary training, consisting of four sections: a warm-up, strength and balance training, gait training and adjusted games. Apart from this plenary training the participants were asked to continue the strength training twice a week at home during 30 minutes.

\section{Warm-up}

The warm-up was the same every week, lasted for approximately 10 minutes and consisted of walking laps in the training hall at an individual pace. During walking various assignments were given:

- Stand still and stretch as far as you can: arms as high as possible over your head while standing on your toes;

- Stand still and 'roll down' starting with your head, vertebra by vertebra;

- Swing your arms and spin around;

- Walk on your toes:

- Walk on your heels;

- Walk with long steps;

- Walk with wide steps;

- Tap your heels against your buttocks;

- Pull up your knees;

- Shake loose your arms and legs.

\section{Strength and balance training}

The strength and balance training was performed sitting on a chair (during most exercises) with a duration of 25 minutes. The exercises were performed with constant resistance during 4 weeks. The first week started out with 3 sets of 4 repetitions. This was increased by 2 repetitions per week until 3 sets of 10 repetitions were performed in the fourth week. After the fourth and eight week the exercise resistance was increased and the participants started with 3 sets of 4 repetitions again, followed by the same schedule. The schedule is schematically presented in a table. 
Table 1. training schedule

\begin{tabular}{lllll}
\hline Week & $1 / 5 / 9$ & $2 / 6 / 10$ & $3 / 7 / 11$ & $4 / 8 / 12$ \\
Number of series x repetitions & $3 \times 4$ & $3 \times 6$ & $3 \times 8$ & $3 \times 10$ \\
\hline
\end{tabular}

The strength and balance training consisted of two components. During the first 12 weeks of the training program it was mainly aimed at the lower leg; the exercises were:

- Resisted plantar flexion. Participant standing up, if necessary supported by a chair. Heel raises with repeatedly standing on toes.

- Coordination of the lower leg muscles. Participant folds and unfolds a towel with feet while sitting on a chair.

- Resisted foot eversion. Participant sits, secures elastic band with predetermined resistance around balls of feet. Feet are placed at hip width on the heels, participant turns the right foot repeatedly from neutral position to eversion and back.

- Balance and stability exercises. Participants in twos, one performs the exercise, the other assists and offers support if necessary. Participant is standing behind a chair, feet at hip width, closes the eyes and stays standing, if possible without support. In the course of the weeks the difficulty level is increased by standing on one leg and finally to standing on one leg with eyes closed.

- Balance and stability exercises. Participants in twos, one performs the exercise, the other assists and offers support if necessary. Participant is standing behind a chair, feet approximately at hip width, lifts feet off the floor and holds the knee in $90^{\circ}$ flexion, closes eyes, if possible without taking support.

- Resisted dorsiflexion and plantar flexion. Participant sits, secures elastic band with predetermined resistance around balls of feet. Participant places heels on the floor, ankle in approximately $90^{\circ}$, the right foot moves toward plantar flexion and back, the left foot is kept still.

- Resisted dorsiflexion and plantar flexion of the foot. Participants in twos, sitting across from each other. One secures elastic band with predetermined resistance around the forefoot, while the other secures both ends under the foot. The first participant moves the foot repeatedly towards dorsiflexion and back to a $90^{\circ}$ angle. 


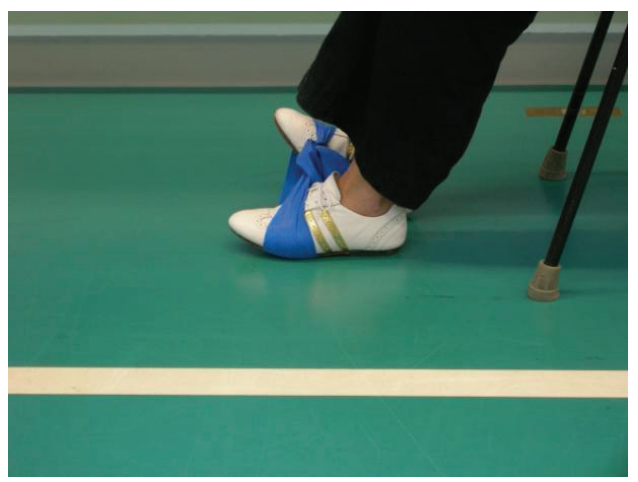

Fig. 1 Example of strength exercise

The second component took place during weeks 13 until 24 and was aimed at strengthening the entire leg; the exercises were:

- Strength training of the hip and knee extensors. Participant sitting with elastic band with predetermined resistance under the right foot, the two ends secured in his or her hands. Starting with the knee at the chest, the leg is repeatedly extended towards the floor and slowly back to the starting position.

- Strength training of the hip and knee extensors. Participant standing in front of a step bench or comparable bench. Participant steps with one foot on the bench followed by the other foot. Then both feet return to the starting position.

- Strength training of the hip and knee extensors. Participants squat starting from a standing position (move buttock backward to relieve the knees), as if they want to pick something up from the floor. Then back to a standing position.

- Strength training of the hip and knee extensors. Participants standing with chair approximately $1 \mathrm{~m}$ in front of them. Participants make lunges forward, alternating right and left leg. Both legs are flexed, the knee of the hind leg in an angle of approximately $90^{\circ}$, with the knee moving towards the floor.

- Strength training of the hip and knee extensors. Participants sitting. Starting from this position each participant moves towards a full standing position, without using the arms/hands, and back to a sitting position. To ensure that the participants are actually sitting down, they must place a cone from the left side of the chair to the right side, or vice versa.

- Strength training of the hip adductors. Participant sitting with soft ball between the knees, the hands are kept on the back. Participant squeezes the ball empty between the knees, and slowly lets it inflate again. 
- Strength training of the hip abductors. Participants sitting with elastic band with predetermined resistance is knotted close-fittingly around the knees. The feet are approximately at hip width on the floor. The knees are alternately pulled away from each other and slowly back towards each other.

- Strength training of the knee flexors. Participants sitting with ball under the heel. Both hands are kept on the back, the ball is pressed flat with the foot, then slowly allowed to inflate.

\section{Gait training}

A gait training was offered during thirty minutes in the form of an exercise track, resulting in coordination training on a functional level.

- Diagonal ramp: ramp is diagonal to the walking direction (imitates slopes).

- Balance beam: path of $6 \mathrm{~m}$ long, $15 \mathrm{~cm}$ broad, two bends at right angles. The feet must be placed entirely on the strip while walking over the path.

- Walking on various surfaces (soft mattress, deep-pile carpet, grass, sand, rubber mats, foam rubber).

- Climbing a ramp, turn and back down: 2-3 benches attached to the wall bars next to each other at an obtuse angle (supervised).

- Cones are placed around the ends of a bench: participant walks in between the bench and the cones (imitates small passage, e.g. around a coffee table).

- Picking up balls from a box on the ground, bring it to another box.

- Stepping over a bench.

- Stepping stones: participant walks the track with long paces.

- Slalom: 6 cones with a stick standing in them, walk between them without touching the sticks or cones.

- Pirouette: on a disk with a diameter of $40 \mathrm{~cm}$, turn 360 degrees without moving off the surface of the disk.

- Sitting down and standing up without arm support, chair is $35 \mathrm{~cm}$ high. To ensure that the participants are actually sitting down, they must place a cone from the left side of the chair to the right side while sitting down, and vice versa. 
- Walking while pushing a ball continuously with the foot, without losing control of the ball.

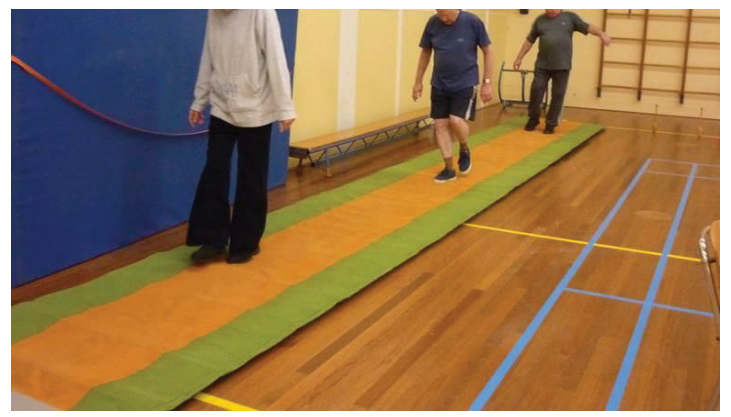

Fig. 2 Gait training

\section{Games}

Each plenary training session was concluded with fifteen minutes of interactive games, such as volleyball, badminton or basketball. Because of the decreased load tolerance of the participants the games were adjusted, e.g. by replacing the ball with a balloon or beach ball. 


\section{Chapter 6}

The use of physical interventions to improve muscle strength, balance and mobility in patients with diabetic polyneuropathy; a systematic review 


\begin{abstract}
Diabetic polyneuropathy is a common co-morbidity in diabetic patients and has been associated with diminished muscle strength, deteriorated balance and impaired mobility. The aim of the current study was to conduct a systematic review to assess the effects of physical training on these outcomes in patients with DPN.

The electronic database Pubmed was searched from inception to December 2013. This review included controlled trials that evaluated the effect of exercise training on muscle strength, balance and mobility in patients with DPN. Due to substantial methodological heterogeneity a quantitative meta-analysis was not performed.

Of the 722 potential relevant studies, 5 studies met the inclusion criteria. Two additional studies were included after searching reference. Hence, seven articles, reporting on six randomized controlled trials, were included in the review. The current data suggest that exercise regimes have a limited positive effect on lower extremity muscle strength in patients with DPN. In general the results of the intervention trials suggest an improvement in balance and mobility after several weeks of functional strength and balance training. However, adverse events are common and can lead to high dropout rates.

Physical training for several weeks can partly reverse the negative consequences of DPN on balance and mobility, although the effects on muscle strength are limited. In addition, not every patient with DPN will be able to perform physical exercises due to adverse events. Pre screening and exercises based on personal capabilities are necessary to get the best chance of the training program to be successful.
\end{abstract}




\section{Introduction}

Diabetes mellitus is the most common cause of peripheral neuropathy worldwide (1). Diabetic polyneuropathy (DPN) occurs in 20 to $40 \%$ of all patients with diabetes $(2,3)$ and at least half of these patients with diabetes mellitus develop DPN after 25 years of diabetes (4). It is presumed that neuropathic symptoms start in the feet and affect more proximal parts of the legs over time (5). The combination of both sensory and motor dysfunction in the lower extremities is one of the characteristic manifestations of DPN. The sensory neuropathy seems more prominent than motor neuropathy due to its clear clinical consequences, such as neuropathic pain or foot ulcers because of loss of protective sensation. The consequences of motor neuropathy, such as muscle atrophy and decreased muscle strength of the lower leg muscles and decreased walking distances $(3,6,7)$, are more subtle and have received, until recent years, less attention. But, several studies in the last decades highlight the impact of DPN, independent of neuropathic pain and foot ulcers, on motor functioning and the health related quality of life of patients with diabetes mellitus $(8,9)$.

DPN can cause marked loss of muscle strength, balance and mobility, and these phenomena are mutual dependent $(7,9-13)$. Due to disturbed motor function muscle strength in the lower leg can be decreased up to $30-50 \%$ (7), in particular in the later phases of the neuropathy. Loss of motorsensory feedback affects balance, which will be further aggravated by the muscle weakness. Each of these abnormalities can contribute to the decreased walking speed $(14,15)$ and loss of mobility in DPN (9). Until now there is no curative treatment for DPN and several researchers tried to answer the question if physical interventions aiming to improve muscle strength and coordination can counterbalance the decrease in balance and mobility in patients with DPN and loss of peripheral nerve function. We hypothesize that a physical intervention focussed on improving lower extremity functioning (e.g. muscle strength and/or balance) leads to improved muscle strength, balance and mobility in patients with DPN. In the last decade the results of several intervention trials have been published on this topic. Therefore, we evaluate in this systematic review the effect on muscle strength, balance and mobility of such physical training programs in patients with DPN. We will summarize results from existing studies, identify the benefits for improvement of muscle strength, balance and mobility in patients, identify possible underlying mechanisms for observed results and provide recommendations how mobility might be improved in subject with DPN based on the current evidence.

\section{Methods}

Search 
The electronic database PubMed was systematically searched by the first (TIJ) and second author (TM) for articles that were published until the 24th of December 2013 and reported on controlled clinical trials that focus on physical interventions based on strength, balance and mobility for patients with DPN.

A broad search strategy was chosen to minimize the chance of missing articles by using the following keywords: *neuropathy AND (intervention OR Exercise OR trial OR training) AND (mobility OR walking OR balance OR gait OR strength OR step* OR fall*)

\section{Selection of studies}

The titles and abstracts retrieved from the initial database search were screened by the first and second author (TIJ and TM) using the inclusion and exclusion criteria as described. In addition, one author (TIJ) screened the reference lists to search for additional articles. For the final decision of inclusion both authors read the full text of the articles that remained relevant after initial screening. Results of in- and exclusion were compared and differences were resolved by discussion.

\section{Inclusion criteria}

Inclusion criteria were: studies published in the English, Dutch and German language; studies involving human subjects with diabetic polyneuropathy (type 1 and type 2 diabetes mellitus); interventions that only contain physical training; intervention and control group both with diabetic polyneuropathy; studies reporting findings for at least one outcome measure of interest in the review, as stated below.

\section{Outcome measures}

Studies were included in the review if they contained at least one of the following outcome measures 1) muscle strength of the lower extremities (plantar and dorsal flexor strength of the ankle and/or extensor and flexor strength of the knee) 2) balance expressed in for example static postural control or walking over obstacles 3 ) mobility determined using physical mobility tests e.g. timed up and go test (TUGT), walking speed or daily step count.

\section{Exclusion criteria}


Exclusion criteria were: all interventions other than physical training (e.g. medical treatment and acupuncture); case studies and other non-controlled studies; other languages than English, Dutch or German.

Assessment of methodological quality of studies

The quality of the studies was assessed by the first two authors (TIJ and TM) using the SIGN 50 instrument (Scottish Intercollegiate Guidelines Network methodology checklist for controlled trials) (16). Results of the quality score were compared and differences between assessors were resolved by discussion.

\section{Results}

Results are summarized in table 1 and 2. In the text of the results section the most important findings have been highlighted.

\section{Search}

Of 722 abstracts retrieved, 20 were identified as potentially eligible and included after a first scan of title and abstract. The 702 articles were excluded from analysis for a variety of reasons: no DPN, medical treatment, reviews, case studies and written in other languages than English, Dutch or German. After full review 15 further articles were excluded because of an inappropriate study design (no control group) or inclusion of patients with nerve deterioration other than DPN. Five articles fulfilled the eligible criteria for inclusion (17-21). By searching the reference lists of the included articles, two additional articles were found, which reported on the same RCT, but with different outcome measures $(22,23)$. Hence, seven articles, reporting on six randomized controlled trials, were included in the review; for the sake of clarity the 2 articles reporting on the same RCT are described as two studies (fig 1). Table 1 displays a summary of the characteristics of participants and effects on outcome parameters in included studies. Due to substantial methodological heterogeneity a quantitative meta-analysis was not performed. 


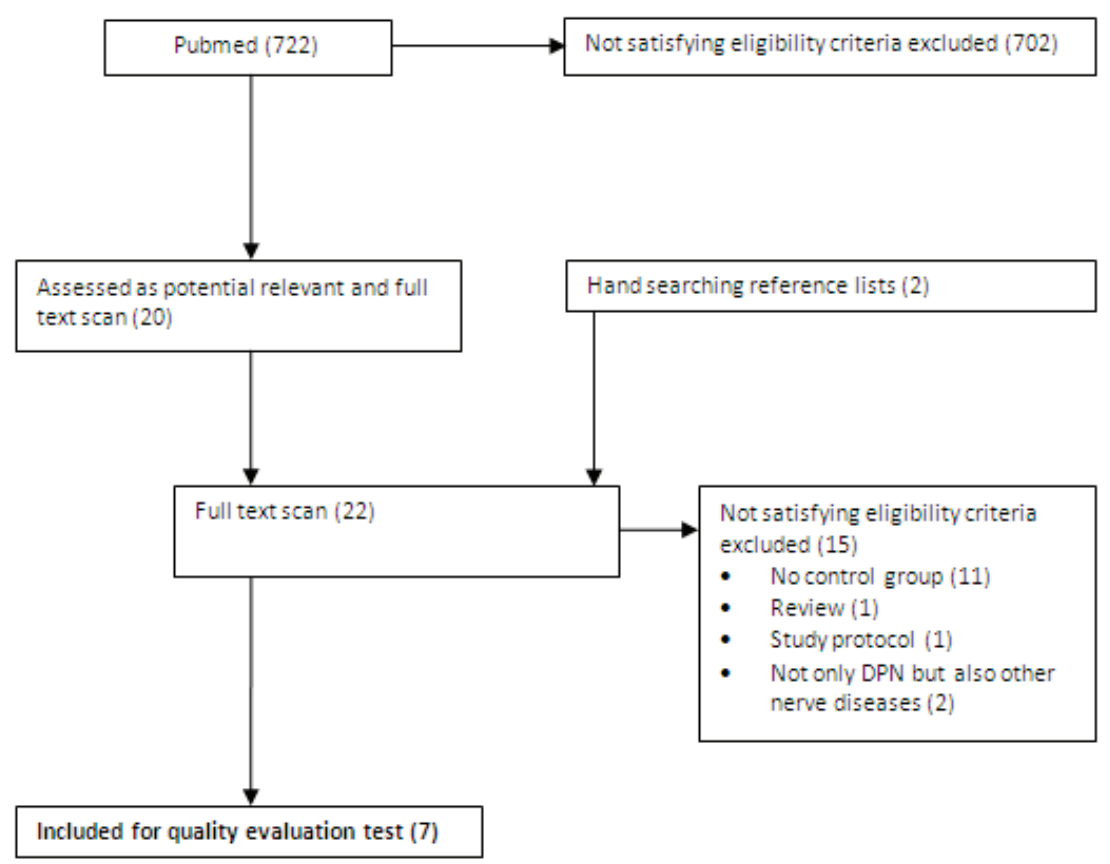

Fig. 1 Flowchart of the studies

\section{Study quality}

A summary of the SIGN quality scores of the seven included is given in table 2 . The quality of five studies were classified as acceptable to high (17, 20-23), one as acceptable (18) and one as low (19). In all studies included in our analysis patients were randomized in an intervention and a control arm. For practical reasons it was not possible to keep both the investigators and subjects blinded in neither one of the studies. Four studies did not use a concealment method during the randomization procedure or did not describe this $(18,19,22,23)$. Three studies did not use an intention to treat analysis (17-19); dropout varied markedly between studies (see table 1) ranging from $0 \%$ to $30 \%$ in either the control and intervention groups.

\section{Interventions}

All studies used comparable physical exercises to improve muscle strength, balance and mobility and these exercises were in general well described. Examples of these exercises are walking on heels or over different surfaces to improve balance and mobility. Muscle strength was trained using subject's own body weight or little weights during exercises, such as rising from a chair, to improve lower 
extremity muscle strength. One study used also whole body vibration (WBV) in combination with balance training as an intervention (17). During the WBV training, patients stood $3 \times 3$ min in a squatting position on a vibrating platform.

Subjects trained two to four times a week for about one hour with one exception, in this study subjects trained every day (19). Four studies reported on intervention programs of twelve weeks (18, $20,22,23)$, one of eight weeks (21), one of six (17) and one of three weeks (19). In five out of seven studies subjects performed the intervention under supervision of a physiotherapist. In one study the supervision during the trainings was not described (19) and in another study subjects had to train at home in addition to the plenary training sessions (21). Three studies also obtained 6-15.5 months follow-up data after the intervention was stopped $(20,22,23)$.

\section{Outcome measures}

Maximal muscle strength of the lower extremities was determined by means of isometric and isokinetic measurements on a (handheld) dynamometer and one study used the "five times sit to stance" test. Balance was determined with single and double leg stance, the Berg Balance scale (BBS), the performance-oriented mobility assessment (POMA), the activities-specific balance and confidence scale, or subjects had to walk over a beam. Mobility was measured using the TUGT, sixminute walk test (6MWT), 10-minute walk test (10MWT), daily step count or determining walking speed over different surfaces.

\section{Subjects}

All studies included patients (approximately 65-75 years of age) with DPN, which was diagnosed based on vibration threshold (21-23), EMG and the Michigan Diabetes Neuropathy Score (19), but in three studies the diagnosis of DPN was not specified $(17,18,20)$. Five studies did not describe the severity of DPN $(17,18,20-22)$, two studies included patients with light to moderate $\operatorname{DPN}(19,23)$. Three studies excluded patients with $\operatorname{DM} 1(20,22,23)$, one study included both DM1 and DM2 patients (21) and in the other studies the type of diabetes was not described (17-19).

\section{Outcome A: Muscle strength}

Muscle strength was reported as an outcome of physical interventions in four studies $(17,20,21,23)$. All reported that a progressive training program of twelve weeks aimed at improving muscle strength of the lower extremities, balance and walking speed, results in improved muscle strength in patients 
with DPN, compared to a control group. Maximal plantar flexor strength at the ankle and maximal flexor strength at the hip was improved by 15 and 31\% compared to baseline data respectively after 12 weeks of training in one study (23). Knee extensor and flexor strength and dorsal flexor strength of the ankle were not affected by strength training in three studies $(20,21,23)$. In comparison to a control group, functional strength of the lower extremity (five times sit to stand test) was improved by 12 to $22 \%$ in one study after six weeks of balance or balance and WBV training respectively (17). In such a test not only muscle strength but also coordination plays an important role.

\section{Outcome B: Balance}

Balance variables were reported in five studies $(17-19,21,23)$, and were measured in a laboratory (e.g. balance platform) or in a daily life setting (e.g. walk over a beam). Patients improved their performance at most of the balance tests after the intervention while no effect was found in the control groups. The unipedal stance time improved by 9 to $115 \%$ in three studies (17-19) while in another study no increased stance time was observed (21). Based on the available data we could not determine the reason of this large variation in effectiveness of training. Balance during standing, measured as postural sway distance, improved in the anterior-posterior and medial-lateral direction with 29 to $37 \%$ and 14 to $34 \%$, respectively $(17,18)$. In two studies an overall balance test was used to assess the balance of the subjects: POMA (23) and the BBS (18). Subjects who participated in the intervention group improved their balance scores significantly by an average of $4 \%$ after the intervention. The time to walk over a $5 \mathrm{~m}$ beam ( $15 \mathrm{~cm}$ high, $15 \mathrm{~cm}$ wide) improved with more than $2.5 \mathrm{~s}(27 \%)$ compared to baseline data (23).

\section{Outcome C: Mobility}

Six articles reported mobility parameters $(17,18,20-23)$. Walking speed, measured under standardized conditions, was the most commonly used outcome parameter but also daily step counts were used once (20). Four studies observed a significant increase in walking speed over a flat surface in the intervention group within a range of 0.07 to $0.15 \mathrm{~m} / \mathrm{s}$ compared to baseline values; range 1.03$1.21 \mathrm{~m} / \mathrm{s}(18,20,22,23)$. The effect of training could be determined by the surface characteristics on which the walking speed is tested, as the largest effect was observed when DPN subjects had to walk over cobblestones $(0.17 \mathrm{~m} / \mathrm{s})(22)$. Overall, these data suggest that an intervention program can result in an improvement of walking speed of 7 to $16 \%$ and that possibly the largest beneficial effects occur when the subject has to walk over a uneven surface. 
The TUGT was used in three studies to determine mobility $(17,18,21)$. Two studies observed a significant decrease in TUGT outcome between 0.8 and $1.8 \mathrm{~s}$ in the intervention group due to an increase in walking speed of 6 to $14 \%(17,18)$. In contrast, another study did not observe significant differences in the outcome of the TUGT between the intervention and control group (21); we could not find an explanation for this difference with the other two studies. In the study that used pedometry, daily step count was significantly increased with 684 steps (14\%) (20).

\section{Outcome D: Adverse events and drop out}

Adverse events of the physical exercise programs were reported in 1 study (20) and were reported in approximately $50 \%$ of the participants. Adverse events and common causes for drop out were calf lesions (12 of 29 subjects (20)), strains (1 of 29 subjects (20)), ulcers (3 of 29 subjects (20)) joint problems due to osteo-arthritis ( 1 of 20 subjects (19)), fatigue ( 3 of 71 subjects $(22,23)$ ) and non defined illness ( 1 of 10 subjects (19), 1 of 71 subjects $(22,23)$ and 2 of 60 subjects $(17)) ;(17,19,20$, $22,23)$. 


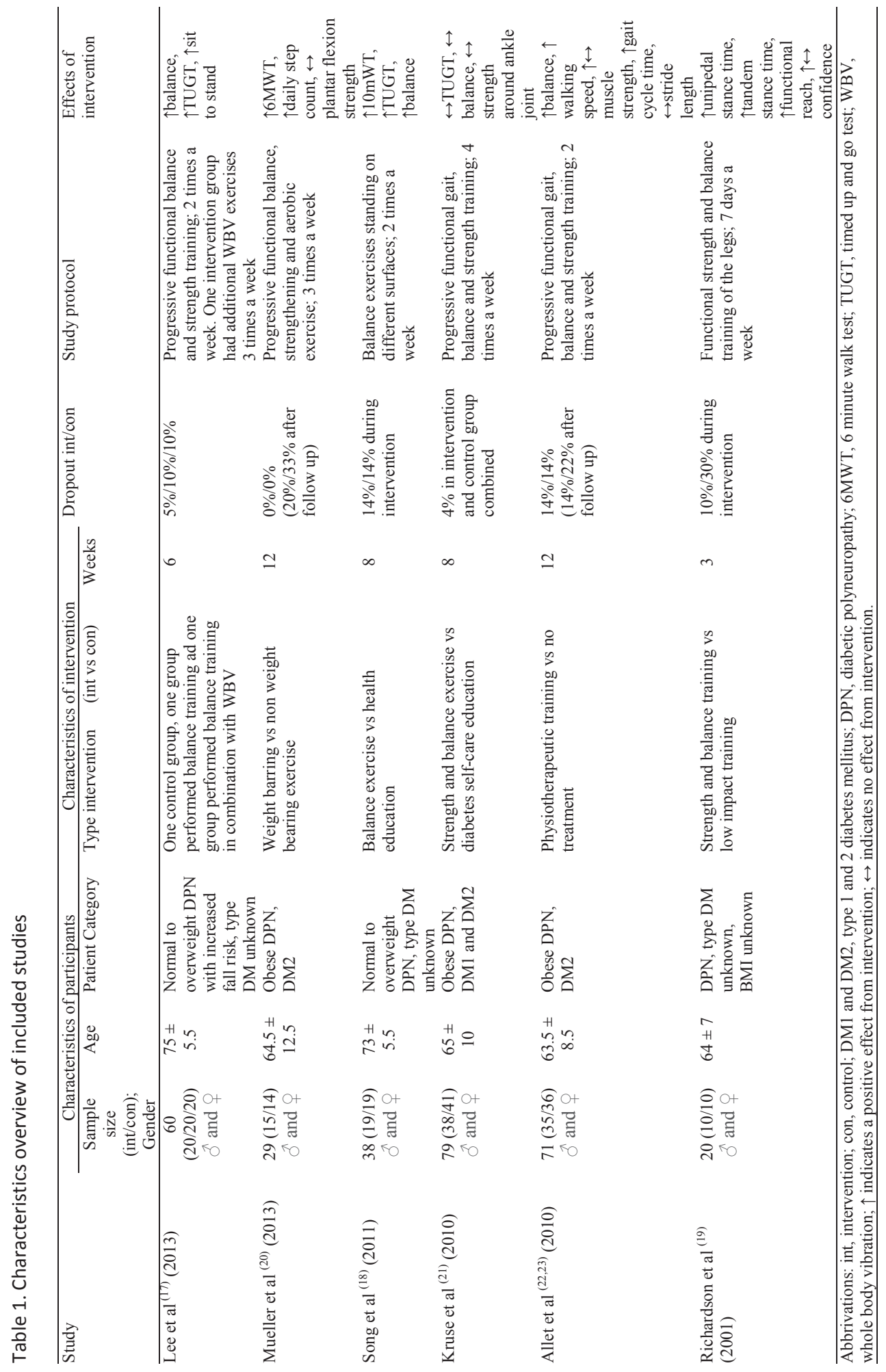




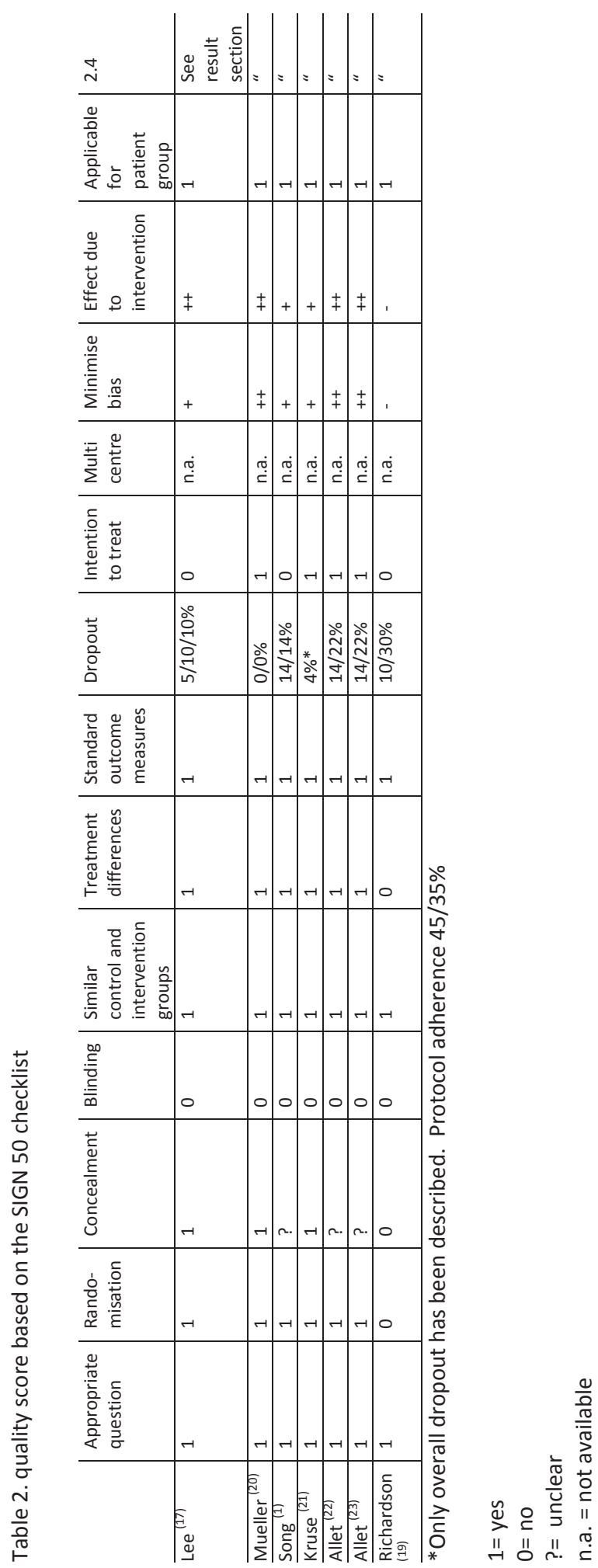




\section{Discussion}

To the best of the authors' knowledge this is the first systematic review of intervention trials investigating the effect of a physical training program on muscle strength, balance and mobility in patients with DPN. The aim of this review was to evaluate whether a physical intervention program leads to a breakthrough of the negative spiral of loss of muscle strength and impaired sensorimotor feedback due to DPN, resulting in diminished balance and inactivity, which then leads to a further decrease in muscle strength and balance control. In general, the interventions reported herein were group exercises to improve functional muscle strength, balance and mobility under supervision of a physiotherapist. Based on these intervention trials we conclude that a physical training program of several weeks can partly reverse the negative consequences of DPN on balance and mobility, although the effects on muscle strength are limited.

Included studies and study quality

We observed a marked variation in the quality of the studies included; three scored high quality for "minimize bias" and "effect due to intervention" while one study scored low on these items of the SIGN 50 (table 2). Furthermore, the included studies from Allet et al. are in fact one study published in two articles describing partially the same outcome measures $(22,23)$.

\section{Muscle strength}

The current data suggest that exercise regimes have a limited positive effect on lower extremity muscle strength in patients with DPN. However, the effect of these interventions varied markedly between studies; this was difficult to explain. These differences are perhaps not solely related to subtle differences in the training programs but also to differences in measuring tools. Maximal strength of isolated muscles is usually measured in a fixed position with a dynamometer. Perhaps tests that measure muscle strength in a more functional way, which is more related to daily life exercises, are easier to perform for these patients and are therefore more able to observe improvements. Standardised ADL-tests might be more applicable and indeed one study reported improvement up to $22 \%$ when muscle strength was measured as the results of the five times sit to stand test (17). When looking at the triad of strength, balance and mobility in DPN, determining functional muscle strength over time, for example by measuring the time needed to rise from a chair, is possibly more relevant than measuring isolated muscle strength with a dynamometer. 
Balance

Several studies observed an improvement in balance after several weeks of functional strength and balance training. In almost every study that aimed at improving balance, patients performed better on static and dynamic balance exercises like standing on one leg with eyes closed or walking over a beam (4-115\%). None of the authors gave a clear description of the physiological and/or mechanical changes that might explain the improvement in balance. One explanation could be that actually the repeated measurement of balance as outcome parameter, such as standing on one leg, will result in neural learning process over time, when balance is impaired. Another possible explanation could be that the physical interventions resulted in a reduction in muscle stiffness. Muscle stiffness is associated with DPN (24), it can disturb the conveyance of sway during standing which in its turn can lead to impaired balance (25). Therefore, it is interesting to determine whether interventions specifically aimed at reducing muscle stiffness lead to improved balance. And in order to further improve the efficacy of intervention programs on balance in DPN the underlying mechanisms of the beneficial effects of these training programs need to be unravelled.

\section{Mobility}

The results of the intervention trials suggest that physical training programs can improve mobility in DPN. Unfortunately, to the best of our knowledge a specific definition of mobility for clinical research is lacking and mobility is currently perhaps more a concept than a quantity. Mobility means "the ability to move" which is a general description and there are many different tests designed to determine mobility; the lack of a well-defined definition hampers the comparison of intervention studies in this systematic review. In general two types of mobility tests were used: measurements of how fast someone moves and measurements of how much someone moves. The first approach includes tests such as TUGT and 6MWT and the second includes for example daily step counts, measured with pedometers. The current results suggest that physical training programs can improve both types of mobility in patients with DPN, patients walked overall 7 to $16 \%$ faster and $14 \%$ more after 3 to 12 weeks of training.

It has been suggested that impairments in lower extremity physical functioning are key contributors to loss of mobility and loss of physical independence, with a major impact on quality of life (9). A close relation has been observed between diminished muscle strength, impaired mobility and quality of life $(7,9)$ and the results of one study not included in this review suggested that physical exercises can improve quality of life of patients with DPN (26). 
As pointed out in this systematic review, a physical training program improves static and dynamic balance in patients with DPN. Walking over an uneven surface demands more complex coordination and DPN has a greater negative effect on walking over an uneven surface than over a flat pathway (22). Interestingly, larger positive effects in mobility outcome parameters were reported when patients had to walk over more difficult surfaces such as a $20 \mathrm{~m}$ cobblestone pathway (22); apparently mobility and strength training can result in marked improvements in tasks requiring complex coordination. In addition to muscle strength and balance also self-confidence plays an important role during walking over beams and difficult surfaces. Self-confidence can improve after a period of physical training in elderly with mobility (27). This was also shown in one study included in this systematic review where patients with DPN seems to improve self-confidence after a period of physical training (19). Clearly, being more self-confident can help a patient to perform better in more challenging mobility tests.

Finally, perhaps the most obvious explanation for the mobility improvement is the increase in physical fitness by physical training in people who are in general sedentary. As people with DPN walk $30 \%$ less when compared to healthy elderly (3) there will be more room for improvement when starting with physical training. This effect of physical training probably also explains why the more marked effects were observed when mobility was measured during a 6MWT (which measures walking speed).

\section{Vulnerability}

The dropout rate varied between 0 to $30 \%$ in the studies included. Patients with DPN frequently have co-morbidities that can cause problems during physical activity, such as autonomic dysfunction, cardiovascular complications, other diabetic complications and also osteo-arthritis (28-31). If present, these co-morbidities increase the risk of dropout during an intervention quite markedly (32) and training with high intensity is therefore not advisable $(26,32)$. There are several reasons for relative low dropout rates in some of the included studies. To avoid high drop-out several trials had strict inclusion criteria limiting the generalizability of the results obtained; moreover, in one study subjects in the intervention group were paid $\$ 10$ for each visit (20). Pre-screening by physicians using strict exclusion criteria (e.g. osteo-arthritis, motivation, increased risk for foot ulcers etc.) and supervision of classified physiotherapists during the exercises is highly recommended in physical exercise programs in DPN.

Practical applications 
The trials included in this review studied the effect of one type of intervention vs. no training and none compared two different intervention programs. It is therefore impossible to determine which kind of intervention is best for patients with DPN to improve functional muscle strength, balance and mobility. In general, patients can improve their balance and mobility after at least six weeks of physical training twice a week, in a training program that consists of supervised functional strength and balance exercises $(17,18,21-23)$. Moreover, these improvements could still be observed nine months after termination of interventions that had a duration of 12 weeks $(22,23)$. It seems that exercises aiming at improving functional strength, balance and mobility such as rising from a chair, walking over different surfaces or standing with eyes closed are in particular useful to improve physical functioning in patients with DPN as long as they are based on the individual physical capacities of each individual patient.

\section{Conclusion}

This systematic review shows that physical intervention of several weeks aimed at improving balance and mobility will lead to improved physical functioning in patients with DPN. Such programs might lead to a breakthrough of the negative spiral of decreased muscle strength resulting in diminished balance and physical inactivity, leading to further impairments in muscle strength and balance. In particular mobility and strength training can result in marked improvements in tasks requiring complex coordination. However, not every patient with DPN will be able to perform physical exercises as described above. Pre screening and exercises based on personal capabilities are necessary to get the best chance of the training program to be successful. It is currently not clear which intervention is the most beneficial, but it seems important to offer patients with DPN a physical training program of functional strength and balance exercises so that they can improve their physical fitness and self-confidence. 


\section{References}

1. Setacci C, de Donato G, Setacci F, Chisci E. Diabetic patients: epidemiology and global impact. J Cardiovasc Surg (Torino). 2009 Jun;50(3):263-73.

2. Cabezas-Cerrato J. The prevalence of clinical diabetic polyneuropathy in Spain: a study in primary care and hospital clinic groups. Neuropathy Spanish Study Group of the Spanish Diabetes Society (SDS). Diabetologia. 1998 Nov;41(11):1263-9.

3. van Sloten TT, Savelberg HH, Duimel-Peeters IG, Meijer K, Henry RM, Stehouwer CD, et al. Peripheral neuropathy, decreased muscle strength and obesity are strongly associated with walking in persons with type 2 diabetes without manifest mobility limitations. Diabetes Res Clin Pract. 2010 Oct 19.

4. Boulton AJ. Lowering the risk of neuropathy, foot ulcers and amputations. Diabet Med. 1998;15 Suppl 4:S57-9.

5. Said G. Diabetic neuropathy--a review. Nat Clin Pract Neurol. 2007 Jun;3(6):331-40.

6. Andersen H, Gadeberg PC, Brock B, Jakobsen J. Muscular atrophy in diabetic neuropathy: a stereological magnetic resonance imaging study. Diabetologia. 1997 Sep;40(9):1062-9.

7. IJzerman TH, Schaper NC, Melai T, Meijer K, Willems PJ, Savelberg HH. Lower extremity muscle strength is reduced in people with type 2 diabetes, with and without polyneuropathy, and is associated with impaired mobility and reduced quality of life. Diabetes Res Clin Pract. 2012 Mar;95(3):345-51.

8. Benbow SJ, Wallymahmed ME, MacFarlane IA. Diabetic peripheral neuropathy and quality of life. Qjm. 1998 Nov;91(11):733-7.

9. van Schie $\mathrm{CH}$. Neuropathy: mobility and quality of life. Diabetes Metab Res Rev. 2008 MayJun;24 Suppl 1:S45-51.

10. Andersen $\mathrm{H}$, Nielsen $\mathrm{S}$, Mogensen $\mathrm{CE}$, Jakobsen J. Muscle strength in type 2 diabetes. Diabetes. 2004 Jun;53(6):1543-8.

11. Andreassen CS, Jakobsen J, Andersen H. Muscle weakness: a progressive late complication in diabetic distal symmetric polyneuropathy. Diabetes. 2006 Mar;55(3):806-12.

12. Andreassen CS, Jakobsen J, Ringgaard S, Ejskjaer N, Andersen H. Accelerated atrophy of lower leg and foot muscles--a follow-up study of long-term diabetic polyneuropathy using magnetic resonance imaging (MRI). Diabetologia. 2009 Jun;52(6):1182-91.

13. Ghanavati T, Shaterzadeh Yazdi MJ, Goharpey S, Arastoo AA. Functional balance in elderly with diabetic neuropathy. Diabetes Res Clin Pract. 2012 Apr;96(1):24-8.

14. Wuehr M, Schniepp R, Schlick C, Huth S, Pradhan C, Dieterich M, et al. Sensory loss and walking speed related factors for gait alterations in patients with peripheral neuropathy. Gait Posture. 2013 Dec 1.

15. Nardone A, Corna S, Turcato AM, Schieppati M. Afferent control of walking: are there distinct deficits associated to loss of fibres of different diameter? Clin Neurophysiol. 2014 Feb;125(2):327-35.

16. Harbour R, Miller J. A new system for grading recommendations in evidence based guidelines. BMJ. 2001 Aug 11;323(7308):334-6.

17. Lee $\mathrm{K}$, Lee $\mathrm{S}$, Song $\mathrm{C}$. Whole-body vibration training improves balance, muscle strength and glycosylated hemoglobin in elderly patients with diabetic neuropathy. Tohoku J Exp Med. 2013;231(4):305-14.

18. Song CH, Petrofsky JS, Lee SW, Lee KJ, Yim JE. Effects of an exercise program on balance and trunk proprioception in older adults with diabetic neuropathies. Diabetes Technol Ther. 2011 Aug;13(8):803-11.

19. Richardson JK, Sandman D, Vela S. A focused exercise regimen improves clinical measures of balance in patients with peripheral neuropathy. Arch Phys Med Rehabil. 2001 Feb;82(2):205-9.

20. Mueller MJ, Tuttle LJ, Lemaster JW, Strube MJ, McGill JB, Hastings MK, et al. Weight-bearing versus nonweight-bearing exercise for persons with diabetes and peripheral neuropathy: a randomized controlled trial. Arch Phys Med Rehabil. 2013 May;94(5):829-38. 
21. Kruse RL, Lemaster JW, Madsen RW. Fall and balance outcomes after an intervention to promote leg strength, balance, and walking in people with diabetic peripheral neuropathy: "feet first" randomized controlled trial. Phys Ther. 2010 Nov;90(11):1568-79.

22. Allet L, Armand S, Aminian K, Pataky Z, Golay A, de Bie RA, et al. An exercise intervention to improve diabetic patients' gait in a real-life environment. Gait Posture. 2010 Jun;32(2):185-90.

23. Allet L, Armand S, de Bie RA, Golay A, Monnin D, Aminian K, et al. The gait and balance of patients with diabetes can be improved: a randomised controlled trial. Diabetologia. 2010 Mar;53(3):458-66.

24. Rao S, Saltzman C, Yack HJ. Ankle ROM and stiffness measured at rest and during gait in individuals with and without diabetic sensory neuropathy. Gait Posture. 2006 Nov;24(3):295-301.

25. Day JT, Lichtwark GA, Cresswell AG. Tibialis anterior muscle fascicle dynamics adequately represent postural sway during standing balance. J Appl Physiol (1985). 2013 Oct 17.

26. Dixit S, Maiya A, Shastry B. Effect of aerobic exercise on quality of life in population with diabetic peripheral neuropathy in type 2 diabetes: a single blind, randomized controlled trial. Qual Life Res. 2013 Dec 11.

27. VanSwearingen JM, Perera S, Brach JS, Wert D, Studenski SA. Impact of exercise to improve gait efficiency on activity and participation in older adults with mobility limitations: a randomized controlled trial. Phys Ther. 2011 Dec;91(12):1740-51.

28. Bruce DG, Davis WA, Davis TM. Longitudinal predictors of reduced mobility and physical disability in patients with type 2 diabetes: the Fremantle Diabetes Study. Diabetes Care. 2005 Oct;28(10):2441-7.

29. Vincent AM, Calabek B, Roberts L, Feldman EL. Biology of diabetic neuropathy. Handb Clin Neurol. 2013;115:591-606.

30. van Kollenburg EG, Lavrijsen JC, Verhagen SC, Zuidema SU, Schalkwijk A, Vissers KC. Prevalence, causes, and treatment of neuropathic pain in Dutch nursing home residents: a retrospective chart review. J Am Geriatr Soc. 2012 Aug;60(8):1418-25.

31. Spallone V, Greco C. Painful and painless diabetic neuropathy: one disease or two? Curr Diab Rep. 2013 Aug;13(4):533-49.

32. Melai T, Schaper NC, ljzerman TH, de Lange TL, Willems PJ, Lima Passos V, et al. Lower leg muscle strengthening does not redistribute plantar load in diabetic polyneuropathy: a randomised controlled trial. J Foot Ankle Res. 2013;6(1):41. 


\section{Chapter 7}

Summery and discussion 


\section{General discussion}

The central objective of this dissertation was to evaluate the influence of diabetic polyneuropathy (DPN) on muscle strength, mobility and health related quality of life (HR-QoL) and the effects of functional resistance and mobility training on these aspects. Moreover, it was evaluated whether an increase in muscle strength, mobility and HR-QoL led to a change in activity level in patients with DPN and if this change was retained after the training program was stopped. In this final chapter the main findings of this dissertation will be summarized and discussed, addressing some methodological issues related to the trials conducted, and discuss potential implications and directions of future research.

\section{Main findings}

\section{Clinical examination DPN}

A clinical neurological examination (CNE) can be variable and inaccurate when compared to electrophysiological testing (1). However, in chapter 2 a study is presented in which we showed that a CNE of DPN developed by Valk and colleagues $(2,3)$, is a reliable method to examine patients with DM2 compared to an electrophysiological evaluation. In addition it is an easy, fast and inexpensive procedure. This CNE developed by Valk assesses the sensory modalities, the anatomic level below which light touch sensation is impaired, and the muscle strength of the feet and the ankle reflexes. Using these modalities, a CNE score can calculated: $<5$ points: no DPN, 5-14 points mild DPN, 15-24 points moderate DPN and $\geq 25$ points severe DPN. We demonstrated in chapter 2 that electrophysiological and clinical testing using the Valk score resulted in the same diagnosis of DPN in patients with DM2. This indicates that for example a general practitioner can use this standardized clinical examination for the assessment of DPN in patients with DM2.

\section{Muscle strength}

In chapter $\mathbf{2}$ and $\mathbf{3}$ a study is presented in which we examined muscle strength of the lower extremities in patients with DM2 with or without mild to moderate DPN and compared the obtained data to healthy age matched elderly. In general, both groups of patients with diabetes had diminished maximal, voluntary muscle strength in knee and ankle extensor and flexor strength compared to healthy elderly. However, no differences were observed between patients with or without mild to moderate DPN. No relation was found between loss of nerve function, either determined on basis of electromyography or based on clinical examination and loss of muscle 
strength. We did observe a moderate loss of compound muscle action potential (CMAP) in the DPN patients, suggesting some loss of muscle mass. However, the parallel loss of muscle strength in both patients with or without mild to moderate DPN suggest that in these patients other factors than loss of motor nerve function are responsible of the reduction in muscle strength.

The data presented in chapter 4 suggest that exercise regimes have a limited positive effect on lower extremity muscle strength in patients with mild to moderate DPN. We observed a significant increase in ankle joint plantar flexor strength after 12 weeks of training. No further increase was observed after 12 and 24 weeks. Importantly, after the half-year follow-up the plantar flexor muscle strength remained $44 \%$ higher in the intervention group than in the control group, indicating a long-term beneficial effect. However, no improvements in muscle strengths of the ankle joint dorsal flexor strength, knee extensor and flexor strength were found. In addition, muscle fatiguebility of the lower extremities did not improve over time. All together, our findings suggest that a 24 week training program can improve muscle strength in patients with mild to moderate DPN; however the effects are limited.

\section{Mobility}

In chapter 3 and 4 a study is presented in which we examined mobility in relation to DM2 and mild to moderate DPN. We showed that the effect of the diabetic state per se was associated negatively with mobility. A six minute walk test (6MWT), timed get up and go test (TUGT), and the Physical Activity Scale of the Elderly (PASE) questionnaire were used to determine mobility. Walking speed and selfreported daily activity were lower in our groups of patients compared to healthy age matched elderly. However, both mobility outcome measures did not differ between patients with and without DPN.

We also demonstrated in chapter 4 that 24 weeks of physical training can improve walking speed in patients with DPN. An increase of 27 meters is considered clinical relevant during the 6MWT (4), patients with mild to moderate DPN improved their distance walked at the 6MWT with 30 meters (6\%) after 12 weeks of training. Improvement in walking speed remained the same after 24 weeks of training and after the half-year follow-up. No improvement in walking speed at the TUGT and the score at the PASE questionnaire was found after the intervention. In a questionnaire specifically developed for our randomized controlled trial (chapter 4) to evaluate the experiences of the subjects, participants reported subjective improvement in physical fitness.

In conclusion, a 24 week intervention as described in chapter $\mathbf{4}$ and $\mathbf{5}$ can improve walking speed in patients with DPN who are able to complete the training; this effect was long lasting. Also, patients who followed the 24 week intervention felt physically fitter. 
Health related quality of life

As described in chapter 3 and 4, the SF36 questionnaire was used to determine health related quality of life (HR-QoL). This questionnaire contains 36 items. It measures health on nine multi-item dimensions based on functional status, well being and overall evaluation of health. Patients with mild to moderate DPN scored six out of the nine SF36 items lower than the healthy elderly. Patients with DM2 but without DPN scored seven of the nine SF36 items lower. Both groups scored lower on items such as: physical and social functioning, pain, vitality and health perception compared to healthy elderly. But, no differences were observed in perceived HR-QoL between both groups of patients.

We showed that there was a clear correlation between HR-QoL and muscle strength and mobility outcome measures, such as plantar flexor strength of the ankle and distance walked at the 6MWT at baseline. Despite the fact that these parameters improved during the intervention, no intervention effects were found in the HR-QoL. Although we expected that the intervention would lead to less physical dependence and improved health perception, we did not find such improvements.

\section{Methodological considerations}

\section{Study populations and designs - external validity}

The participants that were included in the studies described above consisted of a selected group of elderly ( $\geq 50$ years) Caucasian individuals. There is evidence that there are ethnic differences in cardio-metabolic risk profile $(5,6)$ and the development of long-term diabetic complications, such as DPN (7). In addition cultural differences could have an impact on for example HR-QoL. Additional studies with participants from other ethnicities are necessary to confirm our findings in these populations.

We excluded patients with DM1 the reason for this was twofold. Since DM1 usually occurs at a younger age (during childhood), DPN frequently develops at a younger age than in patients with DM2. Secondly, different disease processes play a role in the development of DM1 and DM2, each with a theoretically different effect on nerve integrity. For instance, the development of DM2 is closely associated with several cardiovascular risk factors, such as central obesity and hypertension which are also risk factors for DPN (8). Moreover, subjects with DM2 tend to have a sedentary life style, reduced mobility and loss of muscle strength (9) as also showed in this thesis. Including patients with DM1 and DPN would lead to a less homogeneous group of subjects considering the effect of aging and diabetes on for example muscle strength. Theoretically, in order to determine the interaction between muscle strength and nerve function loss, the inclusion of patients with DM1 
would probably have been more preferable from a scientific point of view. From a clinical point of view, however, given the much larger number of subjects with DM2, we have chosen to include only patients with DM2. Whether the results found in this dissertation can be extrapolated to a population with DM1 is therefore unclear and needs further investigation.

For our main study (chapter 3 and 4) diabetic nurses selected the patients with DPN. Only patients who were known to the general practitioner or internist were contacted. We have opted for the diabetic nurses to make the initial contact with the potential subjects as these nurses play an important role in their daily care.

Overall, the majority of the subjects in our studies had mild to moderate DPN which could explain the fact that we did not find differences in the loss of muscle strength between patients with DM2 and with or without DPN. The distribution of the CNE score in our group of patients was: $64 \%$ mild DPN (CNE score of 5-14), 33\% moderate DPN (CNE score of 15-24) and 3\% had severe DPN (CNE score of 225). It is not known what the normal distribution of the severity of DPN is in a general population of patients with DPN, but given the exclusion criteria applied, it is reasonable to assume that patients with severe DPN are under-represented in our study. We excluded subjects who had severe cardiac disease, renal insufficiency (creatinine $>180 \mu \mathrm{mol} / \mathrm{l}$ ), cerebrovascular disease, muscular disorders, rheumatoid arthritis, foot ulcers in the last six months prior to the intervention and subjects that were not able to walk 6 minutes without walking aids. As diabetic complications tend to cluster, these exclusion criteria might have resulted in a selective loss of patients with more severe DPN (1012). Upon diagnosis with diabetes, 10 to $20 \%$ of the patients have already some signs of nerve damage $(13,14)$. This indicates how important it is to screen elderly for DPN. As mentioned above, severe leg muscle weakness was in particular observed in patients with severe, symptomatic DPN and not in patients with asymptomatic mild to moderate DPN $(10,15)$. The data described in chapter 2, $\mathbf{3}$ and $\mathbf{4}$ are in line with these observations as we could not observe loss of strength which could be ascribed to loss of nerve function. We did observe loss of muscle strength in both patients with DM and mild to moderate DPN, that is probably the result of both loss of muscle mass and decreased muscle quality. These changes are likely multifactorial of origin, and related to changes in e.g. muscle composition, aerobic capacity and metabolism (16-19). With the benefit of hindsight, less strict exclusion criteria for patients to participate in our study might have been better, although this would have increased the risk of drop out. But, by including these more severely ill patients it could have been possible to gain more insights in the effect of muscle strength training in patients with severe DPN.

\section{Study populations and designs - internal validity}




\section{Selection bias}

In randomized controlled trials selection bias may obscure true associations and thus hamper interpretations of obtained results. Selection bias can occur if a proper randomization of subjects is not achieved. In addition, this form of bias often results from selective dropout of the unhealthiest participants. Our randomized trial (chapter 4) had a high dropout: $53 \%$ of the intervention group participants did not complete the one year trial, in part because of intervention related injuries. However, dropout rate was also high in the control group (36\%), and was probably a consequence of the relative poor general health status of these individuals. Patients who dropped out had marginal but significantly higher CNE scores in comparison to patients who did not: 14 and 11 points respectively. This could mean that patients with more severe DPN have a higher risk for dropout, possibly due to the more frequent presence of co-morbidities or greater susceptibility to complications of the training due to more severe sensory loss. Also relatively more women than men dropped out during the study: 50 vs $44 \%$. Men and women did not report different reasons for leaving the trial, suggesting that the women might have been less motivated but no firm conclusions can be drawn. No further differences were observed between subjects who dropped out and those subjects who did not. Seven patients (14\%) from the intervention group dropped out because of intervention related injuries (two subjects with ulceration and five with knee complaints), seven patients $(14 \%)$ because of injuries that were not related to the intervention (e.g. cardiac complaints, cancer and cataract surgery), six (12\%) stopped because of lack of motivation and seven patients (14\%) had various other reasons to quit. Eight subjects (17\%) from the control group refrained because of physical impairments (e.g. cardiac and pulmonary complaints), three (6\%) had motivational problems and six patients (13\%) had other reasons to quit. Overall, half of all subjects that refrained from the study gave physical complaints as a reason to quit, indicating that patients with mild to moderate DPN, who appear to be relatively fit, are yet physically vulnerable. In addition, $20 \%$ of all subjects who refrained from the study indicated motivational problems. Dropout rates were higher than in other, smaller studies (20-26) where the dropout rates were between 0 and $33 \%$ as described in chapter 6. We cannot explain the differences between our study and the other mentioned studies, but one of the reasons could be that our participants suffered more from comorbidities. Another reason for the differences in dropout rates could be that in these aforementioned relatively small studies mostly very motivated subjects were included and lack of motivation was never indicated as reason for dropout in these studies. In one large intervention study including patients with DM2 dropout rates were comparable to the rates we observed (27). The high dropout rates in this latter study and in our study indicate that it is crucial not to underestimate the vulnerability of patients with DM2 and DPN when offering them a physical 
training program and its implications will be discussed below. In future studies, it is important to gain more insight in the reason why subjects drop out in order to prevent including patients to a training intervention who are physically or mentally not able to participate in a long term exercise program or alternatively to individualize the intervention in such a way that it better fits with the limitations of the participants.

We analyzed the data of the subjects who dropped out and those who completed the intervention separately; with this per protocol analysis there is a clear risk for selection bias. The reason that we have nevertheless chosen to use this approach is we tried to determine the possible benefits for those patients who are able to follow a prolonged intervention.

\section{Information bias}

Information bias arises in a clinical study because of misclassification of the level of exposure or errors in the measurements and hence bias in data interpretation. In the present studies, there was a risk for information bias for both the intervention and the measurements that were performed.

The subjects assigned to the intervention were divided over 5 sub-groups to receive weekly plenary training for 24 weeks. The groups were guided by different physical therapists. In order to prevent differences in execution of the exercises both subjects and physiotherapists received an exercise manual with a description and photo's of the exercises. In addition, to prevent different interpretations of the exercises the physiotherapists were supervised by a member of the research team. Subjects of the intervention group had to train twice a week at home; although we asked repeatedly, almost none of the subjects filled out their training diary. Therefore, it is not clear if and how often the subjects performed exercises at home. The use of more objective activity monitors, such as tri-axial accelerometers, can in future studies give more insight in the fact whether a person has actually trained. Although such accerelometers also have clear limitations in detecting muscle strength trainings of isolated extremities.

Lower extremity muscle training was performed at a moderate intensity at 40 to $60 \%$ of one repeated maximum (performing 12-16 repetitions). As DPN patients frequently have multiple comorbidities with elevated risk of injuries and cardiac problems, a moderate training intensity was chosen, it is possible that the training intensity was too low to improve muscle strength in the lower extremities. As described in chapter 4 only strength of the plantar flexor muscle around the ankle improved after training. However, it seems that strength training at a moderate intensity can be successful and sometimes even equally effective as strength training at a high intensity (28). Factors other than training intensity may affect the lack of training response on dorsal flexor strength of the ankle and upper leg strength. Difficulties in execution of the exercises could be one of the reasons 
that no improvement in for example dorsal flexor strength of the ankle was observed in contrast to the plantar flexor strength. The training sessions consisted of general walking exercises and exercises that were aimed to improve specific muscle groups. In order to improve plantar flexion strength, subjects were instructed to perform 'raising heels' exercises and dorsal flexion against resistance. To improve dorsal flexor strength subjects were instructed to perform walking on heels exercises and to pull up their foot against the resistance of an elastic band. Several participants reported that these latter exercises were more difficult to execute and could not always be performed because of imbalance during the exercises. To improve dorsal flexor function, exercises which are easier to execute for DPN patients may be necessary in future training regimens. In addition, maximal strength of isolated muscles was measured in a fixed position with a dynamometer. Perhaps tests that measure muscle strength in a more functional way, which is more related to the daily life exercises that our subjects performed during the training sessions, are easier to perform for patients with DPN and are therefore more able to observe improvements. An example of a standardized functional strength test is the "five times sit to stand test". In one study on the effect of whole body vibration, this test was used in DPN patients and an increase of $22 \%$ in functional strength was determined (22). The TUGT was one of the instruments that was used in the current studies to determine mobility. Although we did not find an intervention effect, a time effect was observed; both the control and intervention group improved their walking speed over time. This finding suggests that a learning effect probably occurred. To get a better overview of mobility behavior during the day, the use of an objective tool, like an activity monitor, is recommended (29).

The aim of our study was to evaluate the effects of functional resistance and mobility training on lower limb muscle strength, mobility and HR-QoL in patients with DPN. Balance was not addressed in our attempt to reverse this physical and psychological spiral. Balance is disturbed in patients with DPN (30-32) and, as described in chapter 6, recent literature suggests that balance plays an important role in the mobility and HR-QoL of patients with DPN (21, 33-35). Unsteadiness leads to an increase in fall risk and is a major determinant for depression in patients with DPN $(33,36)$. Although balance was not measured in the intervention study, participants reported that they felt less unsteady and were less afraid to trip and fall when walking on the street after the intervention. This is in line with earlier studies in which the authors concluded that muscle strength is an important factor in keeping balance (37). Improving muscle strength and balance could lead to decreased risk of falling in patients with DPN (38). In addition, changes in both body sway and stance phase of gait in patients with DPN indicate a more impaired static and dynamic control of balance (25). Diminished somatosensory input from the smaller muscle fibers and muscle weakness can both play an important role in the modulation of the support phase of gait (35). It seems possible to improve 
balance in patients with $\operatorname{DPN}(21,22,24,25)$ and therefore, we recommend including balance exercises in future physical training programs for patient with DPN.

Apart from loss of muscle strength and impaired balance, loss of mobility in DPN could also be related to neuropathic pain. This neuropathic pain can have a major impact on gait (39) and with that decreasing general activity and HR-QoL $(33,40-42)$. Perhaps pain relief with medication may assists patients with painful DPN in obtaining better results during a physical intervention that aims to improve mobility, but this remains to be studied in future interventions $(13,14,43,44)$.

We did not succeeded in improving the HR-QoL of patients with DPN after 24 weeks of physical intervention. Perhaps the objectively measured increases in muscle strength and walking speed were too small to lead to an improvement in the subjective HR-QoL, at least as detectable with the SF36 questionnaire. In addition, including balance exercises in future intervention to improve balance and coordination could perhaps have a positive effect on outcome measures such as "physical functioning" and "general health perception", determined with the SF36 questionnaire. Theoretically, it is also possible that an intervention as described and the improvement in muscle strength and mobility do not affect the outcome measures as determined with the SF36 questionnaire, but for instance a supervised exercise training program in subjects with DM2 was associated with a marked increase in various domains of the SF-36 questionnaire (45).

\section{Clinical implications and valorisation}

The primary goal of this dissertation was to evaluate whether a physical intervention program could counterbalance the downward spiral of loss in muscle strength, mobility and HR-QoL. In addition, we wished to gain more insight into the complex physical and mental problems faced by patients with DPN.

The data obtained in this dissertation show that the loss of muscle strength, mobility and HR-QoL was comparable between patients with DM2 and patients with mild to moderate DPN and was mainly caused by DM2 per se and not by mild to moderate DPN. However, patients with DPN suffer from (severe) co-morbidities $(13,44,46,47)$, disturbed passive and dynamic balance (30-32) and, at a later stage, this deteriorated balance can for example increase the risk of falls $(33,36,38)$. It has been shown that physical interventions can improve balance in patients with $\operatorname{DPN}(21,22,24,25)$. Therefore, it is recommended to prescribe an individualized exercise program for patients with DPN aiming to improve balance and based on the trainability and personal goals of the patient. Subjects who completed the intervention evaluated the intervention positively. Participants experienced exercising with fellow patients as pleasant and they would recommend this intervention to other 
patients. In addition, participants reported that they felt physically fitter after the intervention and they looked forward to go to the plenary sessions. These data indicate that potentially there is a opportunity for patients with DPN to break the downward spiral of reduced muscle strength, loss of mobility and loss of fitness, after following a physical intervention of several weeks.

As described in chapter 6, it is currently not clear which intervention is the most beneficial. But based on the feedback of the subjects and the data obtained in this dissertation, it seems important to offer patients with DPN a physical training program of functional strength and balance exercises so they can improve their physical fitness and self-confidence. It is recommended to train patients twice a week for several weeks in small groups with fellow patients under supervision of a physiotherapist. However, several patients with DPN will not be able to follow a physical training program. Patients with DPN are vulnerable and intrinsic motivation is lacking often, strategies are also necessary to enhance this motivation and willingness to stick to the exercise program. Pre-screening on physical en mental capabilities is recommended to increase the success of a training program for patients with DPN.

\section{References}

1. Dyck PJ, Overland CJ, Low PA, Litchy WJ, Davies JL, O'Brien PC, et al. Signs and symptoms versus nerve conduction studies to diagnose diabetic sensorimotor polyneuropathy: $\mathrm{Cl}$ vs. NPhys trial. Muscle Nerve. 2010 Aug;42(2):157-64.

2. Valk GD, de Sonnaville JJ, van Houtum WH, Heine RJ, van Eijk JT, Bouter LM, et al. The assessment of diabetic polyneuropathy in daily clinical practice: reproducibility and validity of Semmes Weinstein monofilaments examination and clinical neurological examination. Muscle Nerve. 1997 Jan;20(1):116-8.

3. Valk GD, Grootenhuis PA, van Eijk JT, Bouter LM, Bertelsmann FW. Methods for assessing diabetic polyneuropathy: validity and reproducibility of the measurement of sensory symptom severity and nerve function tests. Diabetes Res Clin Pract. 2000 Feb;47(2):87-95.

4. Alfonso-Rosa RM, Del Pozo-Cruz B, Del Pozo-Cruz J, Sanudo B, Rogers ME. Test-retest reliability and minimal detectable change scores for fitness assessment in older adults with type 2 diabetes. Rehabil Nurs. 2014 Sep-Oct;39(5):260-8.

5. Gill JM, Celis-Morales CA, Ghouri N. Physical activity, ethnicity and cardio-metabolic health: does one size fit all? Atherosclerosis. 2014 Feb;232(2):319-33.

6. Celis-Morales CA, Ghouri N, Bailey ME, Sattar N, Gill JM. Should physical activity recommendations be ethnicity-specific? Evidence from a cross-sectional study of South Asian and European men. PLoS One. 2013;8(12):e82568.

7. Sosenko JM. The prevalence of diabetic neuropathy according to ethnicity. Curr Diab Rep. 2009 Dec;9(6):435-9.

8. Tesfaye S, Chaturvedi N, Eaton SE, Ward JD, Manes C, lonescu-Tirgoviste $C$, et al. Vascular risk factors and diabetic neuropathy. N Engl J Med. 2005 Jan 27;352(4):341-50.

9. Dempsey PC, Owen N, Biddle SJ, Dunstan DW. Managing sedentary behavior to reduce the risk of diabetes and cardiovascular disease. Curr Diab Rep. 2014;14(9):522.

10. Andreassen CS, Jakobsen J, Andersen H. Muscle weakness: a progressive late complication in diabetic distal symmetric polyneuropathy. Diabetes. 2006 Mar;55(3):806-12. 
11. Bokan V. Muscle weakness and other late complications of diabetic polyneuropathy. Acta Clin Croat. 2011 Sep;50(3):351-5.

12. Kiziltan ME, Gunduz A, Kiziltan G, Akalin MA, Uzun N. Peripheral neuropathy in patients with diabetic foot ulcers: clinical and nerve conduction study. J Neurol Sci. 2007 Jul 15;258(1-2):75-9.

13. Basic-Kes V, Zavoreo I, Rotim K, Bornstein N, Rundek T, Demarin V. Recommendations for diabetic polyneuropathy treatment. Acta Clin Croat. 2011 Jun;50(2):289-302.

14. Singleton JR, Smith AG. The diabetic neuropathies: practical and rational therapy. Semin Neurol. 2012 Jul;32(3):196-203.

15. Andersen $\mathrm{H}$, Nielsen $\mathrm{S}$, Mogensen $\mathrm{CE}$, Jakobsen J. Muscle strength in type 2 diabetes. Diabetes. 2004 Jun;53(6):1543-8.

16. McGregor RA, Cameron-Smith D, Poppitt SD. It is not just muscle mass: a review of muscle quality, composition and metabolism during ageing as determinants of muscle function and mobility in later life. Longev Healthspan. 2014;3(1):9.

17. Park SW, Goodpaster BH, Strotmeyer ES, de Rekeneire N, Harris TB, Schwartz AV, et al. Decreased muscle strength and quality in older adults with type 2 diabetes: the health, aging, and body composition study. Diabetes. 2006 Jun;55(6):1813-8.

18. Schrauwen P, Schrauwen-Hinderling V, Hoeks J, Hesselink MK. Mitochondrial dysfunction and lipotoxicity. Biochim Biophys Acta. 2010 Mar;1801(3):266-71.

19. Allen MD, Major B, Kimpinski K, Doherty TJ, Rice CL. Skeletal muscle morphology and contractile function in relation to muscle denervation in diabetic neuropathy. J Appl Physiol (1985). 2014 Mar 1;116(5):545-52.

20. Allet L, Armand S, Aminian K, Pataky Z, Golay A, de Bie RA, et al. An exercise intervention to improve diabetic patients' gait in a real-life environment. Gait Posture. 2010 Jun;32(2):185-90.

21. Allet L, Armand S, de Bie RA, Golay A, Monnin D, Aminian K, et al. The gait and balance of patients with diabetes can be improved: a randomised controlled trial. Diabetologia. 2010 Mar;53(3):458-66.

22. Lee $\mathrm{K}$, Lee $\mathrm{S}$, Song $\mathrm{C}$. Whole-body vibration training improves balance, muscle strength and glycosylated hemoglobin in elderly patients with diabetic neuropathy. Tohoku J Exp Med. 2013;231(4):305-14.

23. Mueller MJ, Tuttle LJ, Lemaster JW, Strube MJ, McGill JB, Hastings MK, et al. Weight-bearing versus nonweight-bearing exercise for persons with diabetes and peripheral neuropathy: a randomized controlled trial. Arch Phys Med Rehabil. 2013 May;94(5):829-38.

24. Richardson JK, Sandman D, Vela S. A focused exercise regimen improves clinical measures of balance in patients with peripheral neuropathy. Arch Phys Med Rehabil. 2001 Feb;82(2):205-9.

25. Song CH, Petrofsky JS, Lee SW, Lee KJ, Yim JE. Effects of an exercise program on balance and trunk proprioception in older adults with diabetic neuropathies. Diabetes Technol Ther. 2011 Aug;13(8):803-11.

26. Kruse RL, Lemaster JW, Madsen RW. Fall and balance outcomes after an intervention to promote leg strength, balance, and walking in people with diabetic peripheral neuropathy: "feet first" randomized controlled trial. Phys Ther. 2010 Nov;90(11):1568-79.

27. Praet SF, van Rooij ES, Wijtvliet A, Boonman-de Winter LJ, Enneking T, Kuipers H, et al. Brisk walking compared with an individualised medical fitness programme for patients with type 2 diabetes: a randomised controlled trial. Diabetologia. 2008 May;51(5):736-46.

28. Alegre LM, Aguado X, Rojas-Martin D, Martin-Garcia M, Ara I, Csapo R. Load-controlled moderate and high-intensity resistance training programs provoke similar strength gains in young women. Muscle Nerve. 2014 May 15.

29. van Sloten TT, Savelberg HH, Duimel-Peeters IG, Meijer K, Henry RM, Stehouwer CD, et al. Peripheral neuropathy, decreased muscle strength and obesity are strongly associated with walking in persons with type 2 diabetes without manifest mobility limitations. Diabetes Res Clin Pract. 2010 Oct 19.

30. Lafond D, Corriveau H, Prince F. Postural control mechanisms during quiet standing in patients with diabetic sensory neuropathy. Diabetes Care. 2004 Jan;27(1):173-8. 
31. Nardone A, Godi M, Artuso A, Schieppati M. Balance rehabilitation by moving platform and exercises in patients with neuropathy or vestibular deficit. Arch Phys Med Rehabil. 2010 Dec;91(12):1869-77.

32. Turcot K, Allet L, Golay A, Hoffmeyer P, Armand S. Investigation of standing balance in diabetic patients with and without peripheral neuropathy using accelerometers. Clin Biomech (Bristol, Avon). 2009 Nov;24(9):716-21.

33. Vileikyte L, Peyrot M, Gonzalez IS, Rubin RR, Garrow AP, Stickings D, et al. Predictors of depressive symptoms in persons with diabetic peripheral neuropathy: a longitudinal study. Diabetologia. 2009 Jul;52(7):1265-73.

34. Taveggia G, Villafane JH, Vavassori F, Lecchi C, Borboni A, Negrini S. Multimodal treatment of distal sensorimotor polyneuropathy in diabetic patients: a randomized clinical trial. J Manipulative Physiol Ther. 2014 May;37(4):242-52.

35. Nardone A, Corna S, Turcato AM, Schieppati M. Afferent control of walking: are there distinct deficits associated to loss of fibres of different diameter? Clin Neurophysiol. 2014 Feb;125(2):327-35.

36. Dixit S, Maiya A. Diabetic peripheral neuropathy and its evaluation in a clinical scenario: a review. J Postgrad Med. 2014 Jan-Mar;60(1):33-40.

37. Turcot K, Allet L, Golay A, Hoffmeyer P, Armand S. Postural strategies in diabetes patients with peripheral neuropathy determined using cross-correlation functions. Diabetes Technol Ther. 2012 May;14(5):403-10.

38. Tofthagen C, Visovsky C, Berry DL. Strength and balance training for adults with peripheral neuropathy and high risk of fall: current evidence and implications for future research. Oncol Nurs Forum. 2012 Sep;39(5):E416-24.

39. Watari R, Sartor CD, Picon AP, Butugan MK, Amorim CF, Ortega NR, et al. Effect of diabetic neuropathy severity classified by a fuzzy model in muscle dynamics during gait. J Neuroeng Rehabil. 2014;11:11.

40. Galer BS, Gianas A, Jensen MP. Painful diabetic polyneuropathy: epidemiology, pain description, and quality of life. Diabetes Res Clin Pract. 2000 Feb;47(2):123-8.

41. Benbow SJ, Wallymahmed ME, MacFarlane IA. Diabetic peripheral neuropathy and quality of life. Qjm. 1998 Nov;91(11):733-7.

42. Gore M, Brandenburg NA, Dukes E, Hoffman DL, Tai KS, Stacey B. Pain severity in diabetic peripheral neuropathy is associated with patient functioning, symptom levels of anxiety and depression, and sleep. J Pain Symptom Manage. 2005 Oct;30(4):374-85.

43. Bril V. Treatments for diabetic neuropathy. J Peripher Nerv Syst. 2012 May;17 Suppl 2:22-7.

44. van Kollenburg EG, Lavrijsen JC, Verhagen SC, Zuidema SU, Schalkwijk A, Vissers KC. Prevalence, causes, and treatment of neuropathic pain in Dutch nursing home residents: a retrospective chart review. J Am Geriatr Soc. 2012 Aug;60(8):1418-25.

45. Nicolucci A, Balducci S, Cardelli P, Cavallo S, Fallucca S, Bazuro A, et al. Relationship of exercise volume to improvements of quality of life with supervised exercise training in patients with type 2 diabetes in a randomised controlled trial: the Italian Diabetes and Exercise Study (IDES). Diabetologia. 2012 Mar;55(3):579-88.

46. Said G. Diabetic neuropathy--a review. Nat Clin Pract Neurol. 2007 Jun;3(6):331-40.

47. Vincent AM, Calabek B, Roberts L, Feldman EL. Biology of diabetic neuropathy. Handb Clin Neurol. 2013;115:591-606. 


\section{Appendix}

Nederlandstalige samenvatting (Dutch summary) 
Inleiding

Diabetes mellitus, kortweg diabetes, is een ziekte waar wereldwijd ongeveer 400 miljoen mensen aan lijden. Ook in Nederland komt de ziekte veel voor en groeit het aantal nieuwe patiënten nog steeds zorgwekkend snel. In 2011 hadden 0.9 miljoen Nederlanders de ziekte en de voorspelling is dat dit verder toeneemt naar 1.4 miljoen patiënten in 2025. Diabetes kenmerkt zich door een hoge concentratie bloedglucose, vandaar dat de ziekte in de volksmond ook wel "suikerziekte" heet. Deze hoge concentratie bloedglucose kan veel complicaties tot gevolg hebben. Een van deze complicaties is diabetische polyneuropathy (DPN) dat bij 20-40\% van de patiënten met diabetes voorkomt. Tien tot $20 \%$ van de mensen blijkt al DPN te hebben op het moment dat diabetes wordt gediagnostiseerd. Door de hoge concentratie bloedglucose kunnen zenuwen beschadigen en dit kan bijvoorbeeld leiden tot pijn, gevoelloosheid van de huid, verstoorde bloeddruk en spierkrachtverlies van voornamelijk de onderste extremiteiten. Deze zenuwbeschadigingen zijn op verschillende manieren vast te stellen. De meting die meestal als "gouden standaard" wordt gezien is een elektromyografiemeting (EMG). Door middel van EMG is het mogelijk om onder andere de zenuwgeleidingssnelheid te meten. Daarnaast kan men DPN ook vast stellen met behulp van een meer klinische test. Zo is de Valk-methode ontwikkeld waarbij met eenvoudige tests, zoals het waarnemen van trillingen onder de voet en het testen van de achillespees reflex, de ernst van DPN in kaart kan worden gebracht.

De klachten die ontstaan door DPN, zoals pijn en spierkrachtverlies zullen een grote impact hebben op de kwaliteit van leven van de patiënt. Ouder worden gaat gepaard met spierkrachtverlies (sarcopenie). Diabetes kan een versnelde afname van spierkracht veroorzaken en DPN kan dit proces nog verder versnellen. De afname van spierkracht is geassocieerd met een afname in mobiliteit. De afname van mobiliteit kan zich in vele vormen uiten, bijvoorbeeld minder lopen en meer moeite hebben met lopen, moeilijker traplopen en lastiger uit een stoel op kunnen staan. Dit kan tot gevolg hebben dat patiënten met DPN zich onzekerder voelen en in een sociaal isolement terecht komen. Het gevolg is dat het risico bestaat dat patiënten met DPN in een neerwaartse spiraal komen. Minder spierkracht leidt tot minder mobiliteit en minder mobiliteit leidt tot minder belasting van de spieren en dus een verdere afname van de spierkracht. Dit leidt in toenemende mate tot een afname in mobiliteit wat zowel grote medische als sociale gevolgen kan hebben.

Er bestaat op dit moment nog geen behandeling voor alle deze facetten. Meestal krijgen patiënten met DPN pijnstillers door middel van medicatie om zo een deel van de klachten weg te nemen. Functionele kracht- en mobiliteitstraining krijgen amper aandacht in de (para)medische wereld. Deze trainingsvormen zouden wellicht wel kunnen leiden tot een toename van de spierkracht, mobiliteit en kwaliteit van leven en daarmee zorgen voor het doorbreken van de negatieve spiraal waar 
patiënten met DPN in terecht kunnen komen. Het primaire doel van dit proefschrift is dan ook om te onderzoeken welk effect DPN heeft op de spierkracht, de mobiliteit en de kwaliteit van leven van de patiënten en welk effect een functionele kracht- en mobiliteitstraining heeft op deze fysieke en psychologische parameters.

Om te onderzoeken of de Valk-methode een betrouwbare methode is om DPN te diagnosticeren beschrijven we in hoofdstuk 2 de vergelijking tussen deze methode met de EMG-methode. Daarnaast wordt beschreven of het spierkrachtverlies dat al optreedt bij patiënten met diabetes maar zonder DPN veroorzaakt wordt door een verslechtering van de werking van de zenuwen. Om meer inzicht te krijgen in de afname van spierkracht, mobiliteit en kwaliteit van leven bij patiënten met DPN hebben we in hoofdstuk $\mathbf{3}$ deze groep patiënten vergeleken met patiënten met diabetes maar zonder DPN en met gezonde leeftijdsgenoten. In hoofdstuk 4 wordt beschreven of een functionele kracht- en mobiliteitstraining een positief effect heeft op de spierkracht, de mobiliteit en de kwaliteit van leven bij patiënten met DPN. In hoofdstuk $\mathbf{5}$ is de training zoals die is aangeboden aan de patiënten beschreven. Aangezien er sinds de start van ons onderzoek wat meer aandacht is gekomen voor het trainen van patiënten met DPN is in hoofdstuk 6 wordt aan de hand van een literatuuronderzoek beschreven welke trainingsvorm het meest geschikt is om patiënten met DPN sterker en mobieler te krijgen.

\section{De invloed van een verslechterde zenuwfunctie op de spierkracht}

Uit hoofdstuk 2 blijkt dat met behulp van de Valk-methode het functioneren van zowel de sensorische als motorische zenuwen snel, eenvoudig en betrouwbaar in kaart te brengen is. De patiënten die aan onderzoek hebben deelgenomen bleken voornamelijk milde tot matige DPN te hebben. Slechts bij 3\% van de geïncludeerde patiënten is ernstige DPN gediagnostiseerd. Door patiënten met milde tot matige DPN te vergelijken met patiënten met diabetes maar zonder DPN en gezonde leeftijdsgenoten hebben we kunnen vaststellen dat de afname van de motorische zenuwfunctie niet de oorzaak is van spierkrachtverlies bij patiënten met milde tot matige DPN. Er is namelijk geen verband gevonden tussen de mate van spierkrachtverlies en de afname van de motorische zenuwfunctie. Uit de literatuur blijkt dat additioneel spierkrachtverlies pas optreedt als er sprake is van ernstige DPN. Het lijkt er dus op dat pas bij ernstige schade aan de motorische zenuwen er extra spierkrachtverlies optreedt. 
Het effect van milde tot matige DPN op spierkracht, mobiliteit en kwaliteit van leven

In hoofdstuk 3 hebben we een grote groep patiënten met DPN vergeleken met patiënten met DM2 en gezonde leeftijdsgenoten om zo een beeld te krijgen van het effect van diabetes en DPN op de spierkracht, mobiliteit en kwaliteit van leven. Uit onze resultaten blijkt dat diabetes op zichzelf gepaard gaat met een afname van spierkracht, maar milde tot matige DPN lijkt niet tot een nog verdere afname van spierkracht te leiden. Het blijkt dat spierkrachtverlies bij diabetespatiënten een multifactorieel probleem is, maar dat de afname van de motorische zenuwfunctie hierin geen primaire rol speelt.

Ook de mobiliteit van patiënten met DM2 en DPN neemt af. Zowel de loopsnelheid als de beweeglijkheid over de dag is bij deze patiënten lager dan bij gezonde leeftijdsgenoten. Het blijkt echter dat milde tot matige DPN niet tot een verdere afname van de mobiliteit leidt.

Tot slot blijkt ook de kwaliteit van leven van patiënten met diabetes verslechterd. Milde tot matige DPN lijkt de kwaliteit niet verder te verslechteren. Uit de scores van een vragenlijst blijkt dat de onderzochte patiënten onder andere meer pijn ervaren en zich sociaal meer geïsoleerd voelden in vergelijking met hun gezonde leeftijdsgenoten.

\section{Functionele kracht- en mobiliteitstraining}

Op het eerste oog lijken er weinig verschillen te zitten tussen patiënten met diabetes met of zonder DPN. Toch is bekend dat patiënten met DPN vaak (ernstige) aandoeningen hebben die gekoppeld zijn aan DPN, zoals hart- en vaatproblematiek. Met andere woorden, het is een kwetsbare groep patiënten. Toch wilden we graag weten of het door middel van fysieke training mogelijk is om de negatieve spiraal van het verlies van spierkracht, mobiliteit en kwaliteit van leven te doorbreken. Uit hoofdstuk 4 en 5 blijkt dat een 24-weekse trainingsperiode waarin de proefpersonen 1 keer samen onder leiding van een fysiotherapeut en tweemaal thuis trainden een klein positief effect heeft op de spierkracht en loopsnelheid en dat dit effect minimaal een half jaar na het stoppen van de training behouden blijft. Ondanks deze vooruitgang verbeterde de kwaliteit van leven niet na de training. De proefpersonen gaven verder aan het samen trainen erg prettig te vinden en lotgenoten te adviseren ook deze training te gaan volgen. Verder gaven zij aan dat ze zich zekerder voelden tijdens het lopen. Het bleek echter dat de helft van de proefpersonen de training niet heeft willen/kunnen afmaken. Ook in de controlegroep, die geen extra training aangeboden kreeg, was er sprake van een grote uitval. Ongeveer een derde van de mensen uit de controlegroep heeft het onderzoek niet afgerond. Van alle uitvallers viel de helft uit met fysieke klachten terwijl $20 \%$ van de uitvallers stopte omdat ze 
niet meer gemotiveerd waren om deel te nemen. Dit geeft nog maar eens aan hoe fysiek kwetsbaar patiënten met DPN zijn en hoe belangrijk motivatie is. Een goede screening voor aanvang van een trainingsprogramma om de belastbaarheid van een patiënt in kaart te brengen en waarbij ook rekening gehouden wordt met de intrinsieke motivatie is dan ook essentieel.

\section{DPN en balans}

Uit de literatuurstudie die beschreven is in hoofdstuk 6 blijkt dat niet alleen spierkracht, mobiliteit en kwaliteit van leven belangrijke factoren zijn die het fysiek en psychologisch functioneren bij patiënten met DPN bepalen. Balans speelt hierin ook een belangrijke rol. Het blijkt dat de balans, zowel statisch als dynamisch, verstoord kan zijn bij patiënten met DPN. Dit kan zowel fysieke gevolgen hebben (minder mobiel, grotere kans op vallen) als psychische gevolgen (onzekerheid tijdens lopen). Patiënten met DPN kunnen hun balans verbeteren door middel van fysieke training.

Hoe lang en hoe vaak een patiënt moet trainen om spierkracht, mobiliteit en balans te verbeteren is niet geheel duidelijk. Het lijkt erop dat patiënten minimaal enkele weken 2 keer per week moet trainen om een positief effect te bereiken.

\section{Conclusie}

Uit dit proefschrift blijkt dat patiënten met milde of matige DPN die relatief gezond en gemotiveerd zijn baat kunnen hebben bij functionele kracht- en mobiliteitstraining. Zij kunnen daarmee de negatieve spiraal van een verminderde spierkracht en mobiliteit waarin ze dreigen te komen wellicht doorbreken. Hoeveel weken en hoe vaak per week een patiënt moet trainen is nog niet geheel duidelijk en zal verder onderzocht moeten worden. Afgaande op de feedback van de deelnemers lijkt het verstandig om vooral in kleine groepjes te trainen met lotgenoten onder leiding van een fysiotherapeut en de trainingen moeten gebaseerd zijn op de individuele belastbaarheid. Het advies is om ook balansoefeningen toe te voegen aan de trainingen. Hierdoor is zowel de balans als het zelfvertrouwen van patiënten met DPN te verbeteren. Het is belangrijk om in te zien dat patiënten met DPN fysiek kwetsbaar zijn en dat daarnaast intrinsieke motivatie om deel te nemen aan een trainingsprogramma vaak ontbreekt. Van te voren screenen op de belastbaarheid en de echte wil om deel te nemen is daarom essentieel. Dit zal de uitval zeer waarschijnlijk terugdringen. 
Dankwoord (Acknowledgements) 
Beste lezer,

U bent aanbeland bij, voor velen, het meest populaire deel van een proefschrift: het dankwoord. Het feit dat ik lang, erg lang aan dit proefschrift gewerkt heb betekent logischerwijs dat er veel mensen de revue zijn gepasseerd en op één of andere manier een rol hebben gespeeld tijdens mijn promotie. Zonder iemand tekort willen doen kan ik helaas niet iedereen individueel bedanken, maar uiteraard ben ik er mij van bewust dat zonder de hulp van velen dit proefschrift hoe dan ook nooit was geschreven. Natuurlijk wil ik wel graag even stilstaan bij een aantal mensen.

Nicolaas, onze samenwerking laat zich misschien wel het beste omschrijven als een betrouwbare dieselauto. Één van de lange adem, en één waar ik altijd op terug kon vallen. De wijze lessen kwamen vooral toen mijn formele tijd als promovendus erop zaten. De eerste 5 jaar hebben bijna alleen maar uit meten, meten en meten bestaan. Daarna ben ik, vaak heel erg part time, achter de computer gekropen om de resultaten op papier te zetten. De steun die ik in deze lange periode heb gekregen waardeer ik oprecht. Er is nooit sprake geweest van druk ook niet in moeilijke tijden. De momenten die wij bij elkaar zaten of aan de telefoon aan het brainstormen waren brachten motivatie om door te gaan. Meer kan een promovendus niet wensen van zijn promotor.

Hans, jouw rol als dagelijks begeleider en op het allerlaatste moment als promotor is samen te vatten in de woorden, kalm en vertrouwen. Twee aspecten die meermalen zeer goed van pas zijn gekomen gedurende dit lange traject. Door jouw manier van begeleiden is dit proefschrift er uiteindelijk ook echt gekomen. Om de woorden te gebruiken die je ten tijden van onze Zuid Afrika-reis vaak gebruikte: "Baie dankie!"

Kenneth, bedankt voor de sparringsmomenten. Samen brainstormen over vakinhoudelijke zaken was altijd een genoegen, net als de biertjes op vrijdagmiddag in de Thembies overigens. Waardevol waren ook de momenten dat we het over andere zaken hadden dan het onderzoekswerk. Jij hebt mij geleerd dat Amsterdamse bravoure, je niet zo snel opzij laten drukken, heel nuttig kan zijn voor een onderzoeker.

Tom, man, we zouden ook samen nog wel een boek kunnen schrijven over alles wat we tijdens onze promotie hebben meegemaakt en de tijd daarvoor. Jij bent een vriend van bijna het eerste studentenuur. En na huisgenoot en studiegenoot (het MECC hoeft niet meer te vrezen) zijn we gelukkig ook collega's geworden. Ik durf te beweren dat het project uiteindelijk goed is afgerond omdat jij aangesloten bent. We hadden aan één blik genoeg om te weten wat moest gebeuren en als 
het een keer zwaar was trok je mij er doorheen. Bedankt kerel. En ook al zien we elkaar maar heel sporadisch, het is altijd weer mooi om elkaar te treffen.

Paul, ik kan niet genoeg benadrukken hoe onmisbaar jij bent geweest voor het project met je Matlabkennis, maar er is iets wat mij voor altijd bij zal blijven. Jij hebt mij laten inzien dat je werkt om te leven en niet leeft om te werken. Hard werken als het moet en genieten van al het moois om je heen als het kan. Een les die iedereen ter harte zou moeten nemen.

Janneke en Rachel, meiden bedankt voor alle leuke momenten. Samen met Tom en mij waren we promovendi van het "eerste uur". Ik heb het getroffen met jullie als kamergenootjes. En de reis naar Zuid Afrika met Hans, Kenneth, Tom, Ton en jullie was er één om nooit meer te vergeten.

Ralph, Patty, Joan, Antoine, Jan Willem, Jean, Ton. Bedankt voor jullie bijdrage aan het project. Jullie hulp was onmisbaar.

David, you gave my dissertation the perfect finishing touch with your creative skills. You felt what was needed to give content a perfect fitting jacket. Thank you so much.

Maarten, Ronald, Jelte, Mathieu, Paul en alle andere vrienden. Bedankt voor het vooral niet te vaak over mijn promotie te hebben en soms juist even wel omdat het gewoon lekker is om elkaar af en toe te zieken. Het heeft goed geholpen het een en ander te relativeren, promoveren de relativiteitstheorie 2.0 zeg maar. Ik heb veel met jullie meegemaakt, mooi, had ik nooit willen missen.

Karlijn, je hebt het grootste gedeelte van mijn pormotie meegemaakt. Bedankt voor je steun toentertijd en de schop onder mijn kont die af en toe noodzakelijk was om door te blijven gaan.

Va en mams, wat ben ik zonder jullie. De veilige thuisbasis, nu in Ruurlo, is nog precies hetzelfde als toen ik opgroeide. Bedankt voor de wijze levenslessen en de beste opvoeding die ik mij heb kunnen wensen. Bedankt ook voor het nooit aflatende vertrouwen. Dit proefschrift draag ik op aan jullie.

Frouk, lieve zus. Ik denk dat er niemand trotser is dan jij en dat is wederzijds. We waren al beste vriendjes van heel kleins af aan en dat zal de rest van ons leven zo blijven.

Lieve Juul het is zo ontzettend goed, met als levend bewijs onze Lucas! Mijn thuis is waar jullie zijn. 
Curriculum Vitae \& Publications 


\section{Curriculum Vitae}

Herman IJzerman was born in Edam-Volendam on May 6, 1981. He moved to Lochem and attended secondary school at the Staring College, after which he moved to Maastricht to study General Health Sciences with a specialization in Human Movement Sciences at the Maastricht University in 2000. In 2004, he obtained his master degree in General Health Sciences.

After his study, Herman worked as a research assistant at several departments at the Maastricht University and the Medical Centre. In March 2006, he obtained a position as PhD-student at the faculty of General Health Sciences. As a PhD-student, Herman set-up and performed the clinical trial as presented in this dissertation. In addition he worked as a tutor and besides teaching he was involved in the coordination of graduation projects of students at the department of General Health Sciences at the Maastricht University.

In 2011, Herman started as a content manager at Topsport Topics in Amsterdam, where he gives practical advice to all Olympic head coaches in the Netherlands based on sport scientific research and knowledge.

\section{Publications}

T. Herman IJzerman, Nicolaas C. Schaper, Tom Melai, Valeria Lima Passos, Kenneth Meijer, Paul J.B. Willems, Hans H.C.M. Savelberg. Resistance training improves plantar flexor strength and walking speed in people with diabetic polyneuropathy. Submitted

T. Herman IJzerman, Tom Melai , Nicolaas C. Schaper, Kenneth Meijer, Hans H.C.M. Savelberg. The use of physical interventions to improve muscle strength, balance and mobility in patients with diabetic polyneuropathy; a systematic review. Submitted

Tom Melai, Nicolaas C. Schaper, T. Herman IJzerman, Paul J.B. Willems, Ton L. de Lange, Kenneth Meijer, Louis G. Lieverse, Hans H.C.M. Savelberg. Strength training affects lower extremity gait kinematics, not kinetics, in people with diabetic polyneuropathy. J. Appl. Biomech. 2014 Apr; 30(2):221-230

Tom Melai, Nicolaas C. Schaper, T. Herman IJzerman, Ton L. de Lange, Paul J.B. Willems, Valeria Lima Passos, Louis G. Lieverse, Kenneth Meijer, Hans H.C.M. Savelberg. Lower leg muscle strengthening does not redistribute plantar load in diabetic polyneuropathy: a randomised clincical trial. J. Foot Ankle Res. 2013 Oct; 18;6(1):41

Tom Melai, Nicolaas C. Schaper, T. Herman IJzerman, Ton L. de Lange, Paul J.B. Willems, Kenneth Meijer, Louis G. Lieverse, Hans H.C.M. Savelberg. Increased forefoot loading is associated with an increased plantar flexion moment. Hum. Mov. Sci. 2013 Aug; 32(4):785-793 
T. Herman IJzerman. Compressiekleding: beter sporten onder druk? Effecten op prestatie, herstel en blessures. Sportgericht. 2013; 67(6)

T. Herman IJzerman, Nicolaas C. Schaper, Tom Melai, Kenneth Meijer, Paul J.B. Willems, Hans H.C.M. Savelberg. Lower extremity muscle strength is reduced in people with type 2 diabetes, with and without polyneuropathy, and is associated with impaired mobility and reduced quality of life. Diabetes Res. Clin. Pract. 2012 Mar;95(3):345-51

T. Herman IJzerman, Nicolaas C. Schaper, Tom Melai, Paul Blijham, Kenneth Meijer, Paul J.B. Willems, Hans H.C.M. Savelberg. Motor nerve decline doe not underlie muscle weakness in type 2 diabetic polyneuropathy. Muscle Nerve. 2011 Aug; 44(2):241-5

Tom Melai, T. Herman IJzerman, Nicolaas C. Schaper, Paul J.B. Willems, Kenneth Meijer, Hans H.C.M. Savelberg. Calculation of plantar pressure-time integral, an alternative approach. Gait and Posture. $2011 \mathrm{Jul} ; 34(3): 379-383$

Lara Allet, T. Herman IJzerman, Kenneth Meijer, Paul J. B. Willems, Hans H.C.M. Savelberg. The influence of stride-frequency on plantar foot-pressures and joint moments. Gait and Posture. 2011 Jul:34(3)300-306

Tom Melai, T. Herman IJzerman, Ton L. de Lange, Nicolaas C. Schaper, Paul J.B. Willems, Kenneth Meijer, Hans H.C.M. Savelberg. Adverse plantar pressures are associated with increased plantar flexion moments at the first part of the stance phase. Nederlands Tijdschrift voor Diabetologie. 2011; 11(9):127

T. Herman IJzerman, Nicolaas C. Schaper, Tom Melai, Paul J.B. Willems, Kenneth Meijer, Hans H.C.M. Savelberg. Specific strength training enhances uscle strength and functional mobility in diabetic patients with polyneuropathy. Nederlands Tijdschrift voor Diabetologie. 2011; 11(9):127

T. Herman IJzerman, Tom Melai, Kenneth Meijer, Nicolaas C. Schaper, Paul J.B. Willems, Hans H.C.M. Savelberg. Relation between muscle strength and moblity in diabetic patients with and without diabetic polyneuropathy. Nederlands Tijdschrift voor Diabetologie. 2011; 11(7):123-124

Hans H.C.M. Savelberg, T. Herman IJzerman, Tom Melai, Nicolaas C. Schaper, Paul J.B. Willems, Kenneth Meijer. Changes in ankle joint moments underlie redistribution of plantar pressure patterns. Nederlands Tijdschrift voor Diabetologie. 2011; 11(7):119-120

Twan ten Haaf, T. Herman IJzerman, Hans H.C.M. Savelberg. KinesioTaping; een sterk verhaal? Sport en Geneeskunde. 2011 Jul; 44(3):14-19

Judith G.P. van Can, T. Herman IJzerman, Luc, J.C. van Loon, Fred Brouns, Ellen E. Blaak. Reduced glycaemic and insulinaemic responses following isomaltulose ingestion: implications for postprandial substrate use. Br. J. Nutr. 2009 Nov;102(10):1408-1413

Tom Melai, T. Herman IJzerman, Ton L. de Lange, Paul J.B. Willems, Kenneth Meijer, Nicolaas C. Schaper, Hans H.C.M. Savelberg. Gait and Posture. 2008; 28(s2):S87-S88

S.C. Luijendijk, T. Herman IJzerman, Chris P. van der Grinten. Oxygen isotope fractionation in healthy subjects and in patients with COPD. Resir. Physiol. Neurobiol. 2007 Aug;157(2-3): 335-340 